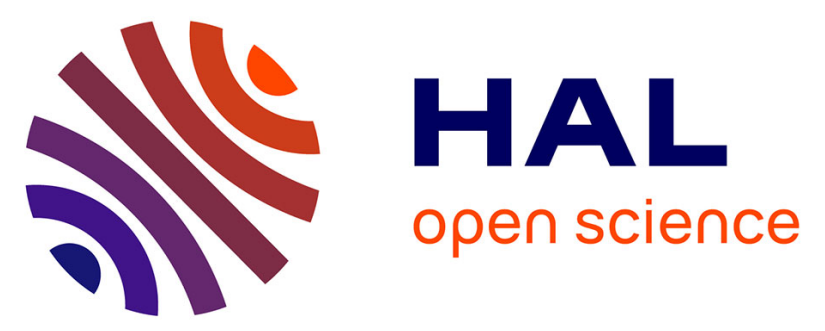

\title{
Synthesis, biological evaluation and molecular modeling of urea-containing MraY inhibitors
}

\author{
Martin Oliver, Laurent Le Corre, Mélanie Poinsot, Alessandra Corio, Léa \\ Madegard, Michaël Bosco, Ana Amoroso, Bernard Joris, Rodolphe Auger, \\ Thierry Touzé, et al.
}

\section{To cite this version:}

Martin Oliver, Laurent Le Corre, Mélanie Poinsot, Alessandra Corio, Léa Madegard, et al.. Synthesis, biological evaluation and molecular modeling of urea-containing MraY inhibitors. Organic \& Biomolecular Chemistry, 2021, 19 (26), pp.5844-5866. 10.1039/D1OB00710F . hal-03432617

\section{HAL Id: hal-03432617 https://hal.science/hal-03432617}

Submitted on 22 Nov 2021

HAL is a multi-disciplinary open access archive for the deposit and dissemination of scientific research documents, whether they are published or not. The documents may come from teaching and research institutions in France or abroad, or from public or private research centers.
L'archive ouverte pluridisciplinaire HAL, est destinée au dépôt et à la diffusion de documents scientifiques de niveau recherche, publiés ou non, émanant des établissements d'enseignement et de recherche français ou étrangers, des laboratoires publics ou privés. 


\title{
Synthesis, Biological Evaluation and Molecular Modeling of Urea-Containing MraY Inhibitors $\dagger$
}

\author{
Martin Oliver, ${ }^{a}$ Laurent Le Corre, ${ }^{\mathrm{a}}$ Mélanie Poinsot, ${ }^{\mathrm{a}}$ Alessandra Corio, ${ }^{\mathrm{a}}$ Léa Madegard, ${ }^{\mathrm{a}}$ Michaël Bosco, ${ }^{\mathrm{a}}$ \\ Ana Amoroso, ${ }^{b}$ Bernard Joris, ${ }^{b}$ Rodolphe Auger, ${ }^{c}$ Thierry Touzé, ${ }^{c}$ Ahmed Bouhss, ${ }^{d}$ Sandrine Calvet- \\ Vitale $^{a, *}$ and Christine Gravier-Pelletier ${ }^{a, *}$
}

\begin{abstract}
The straightforward synthesis of aminoribosyl uridines substituted by a $5^{\prime}$-methylene-urea is described. Their convergent synthesis involves the urea formation from various activated amides and an azidoribosyl uridine substituted at the $5^{\prime}$ position by an aminomethyl group. This common intermediate resulted from the diastereoselective glycosylation of a phthalimido uridine derivative with a ribosyl fluoride as a ribosyl donor. The inhibition of the MraY transferase activity by the synthetized 11 urea-containing inhibitors was evaluated and 10 compounds revealed MraY inhibition with $\mathrm{IC}_{50}$ ranging from $1.9 \mu \mathrm{M}$ to 16.7 $\mu \mathrm{M}$. Their antibacterial activity was also evaluated on a panel of Gram-positive and Gram-negative bacteria. Four compounds exhibited a good activity against Gram-positive bacterial pathogens with MIC ranging from 8 to $32 \mu \mathrm{g} / \mathrm{mL}$, including methicillin resistant Staphylococcus aureus (MRSA) and Enterococcus faecium. Interestingly, one compound also revealed antibacterial activity against Pseudomonas aeruginosa with MIC equal to $64 \mu \mathrm{g} / \mathrm{mL}$. Docking experiments predicted two modes of positioning of the active compounds urea chain in different hydrophobic areas (HS2 and HS4) within the MraY active site from Aquifex aeolicus. However, molecular dynamics simulations showed that the urea chain adopts a binding mode similar to that observed in 5CKR structural model and targets the hydrophobic area HS2.
\end{abstract}

\section{Introduction}

Antimicrobial-resistant bacterial infections represent a severe threat for public health ${ }^{1,2}$ that might be one of the world's major issues in this century. These infections are predicted to be responsible by 2050 for 10 million people dying every year, ${ }^{3}$ with serious incidence on economy, ${ }^{4,5}$ increase morbidity and mortality. ${ }^{6,7}$ During the last decades, major pharmaceutical companies have reduced their R\&D efforts in the search for new antibiotics, mainly because of economic issues. ${ }^{8}$ Therefore, to delay the emergence of resistance, there is an urgent need to develop new antibiotics with modes of action that are different from the ones targeted by the existing drugs. The biosynthesis of peptidoglycan, a major component of cell wall, involves an array of enzymes that have been demonstrated essential for bacterial growth and represent promising targets for the development of new antibiotics. ${ }^{9}$ Even if the late steps of this biosynthesis, located at the outer side of the membrane, are the target of the wellknown $\beta$-lactams, with several generations of potent antibiotics such as ceftaroline, ceftobiprole or razupenem, ${ }^{10}$ the membrane ${ }^{11}$ and intra-cytoplasmic ${ }^{12}$ steps are largely underexploited. In this respect, the bacterial MraY transferase that catalyzes the first membrane-associated step of the peptidoglycan biosynthesis is a pertinent target, since this enzyme is ubiquitous in bacteria and its inhibition could provide antibiotics active against Gram-positive and Gram-negative infections. Peptidoglycan biosynthesis involves first several cytoplasmic steps ${ }^{12}$ from UDP-GIcNAc to afford UDP-N-

\footnotetext{
a Université de Paris, Faculté des Sciences, UMR CNRS 8601, LCBPT, F-75006 Paris, France. E-mail for C. G.-P.: christine.gravier-pelletier@u-paris.fr, E-mail for S. C.-V.: sandrine.calvet-vitale@u-paris.fr

b Unité de Physiologie et Génétique Bactériennes, Centre d'Ingénierie des Protéines, Département des Sciences de la Vie, Université de Liège, Sart Tilman, B4000 - Liège 1- Belgique.

' Institute for Integrative Biology of the Cell (I2BC), CNRS, Universite Paris Sud, CEA, F-91405, Orsay, France.

¿ Laboratoire Structure-Activité des Biomolécules Normales et Pathologiques (SABNP), Univ Evry, INSERM U1204, Université Paris-Saclay, 91025 Evry, France.

${ }^{+}$Electronic supplementary information (ESI) available: 1. Numbering system, $2 .{ }^{1} \mathrm{H}$ and ${ }^{13} \mathrm{C} \mathrm{NMR}$ spectra of all new compounds.
} 
acetylmuramoyl-pentapeptide (UDP-MurNAc-pentapeptide) which is the substrate of the bacterial MraY transferase. Then, associated with the plasma membrane, MraY transfers the phospho-MurNAcpentapeptide moiety from this cytoplasmic precursor (UDP-MurNAc-pentapeptide) to the membrane soluble undecaprenyl-phosphate $\left(\mathrm{C}_{55}-\mathrm{P}\right)$, yielding undecaprenyl-pyrophosphoryl-MurNAcpentapeptide (lipid I) and releasing uridine monophosphate. ${ }^{13}$

Several families of natural MraY inhibitors are known including the well-represented nucleosidic inhibitors such as tunicamycin, ${ }^{14}$ liposidomycins, ${ }^{15}$ caprazamycins ${ }^{16}$ and muraymycins ${ }^{17}$ (Fig. 1) which share a common aminoribosyl uridine skeleton demonstrated important for their biological activity. ${ }^{18}$ However, the chemical structure of these compounds is very different showing that the MraY enzyme is able to accommodate nucleosidic inhibitors with various core structures. The represented absolute configuration at C5' of these compounds (Fig. 1) is also mandatory for MraY inhibition. ${ }^{18 a}$ Most of these compounds are selective for bacterial MraY transferase inhibition except tunicamycin which is cytotoxic because it inhibits both MraY and its eukaryotic paralog GlcNAc-1P-transferase (GPT). ${ }^{19}$ Many simplified analogs of these natural products have been synthetized ${ }^{20}$ to establish structure-activity relationships of these compounds that display various antibacterial activities and different modes of inhibition. ${ }^{21}$ For instance, carbacaprazamycin (Fig. 1 ) ${ }^{22}$ is a chemically stable analog of caprazamycin in which the complex lateral chain of caprazamycin has been replaced by a simpler heptadecanyl alkyl chain. This analog revealed comparable activities to those of the parent caprazamycin.
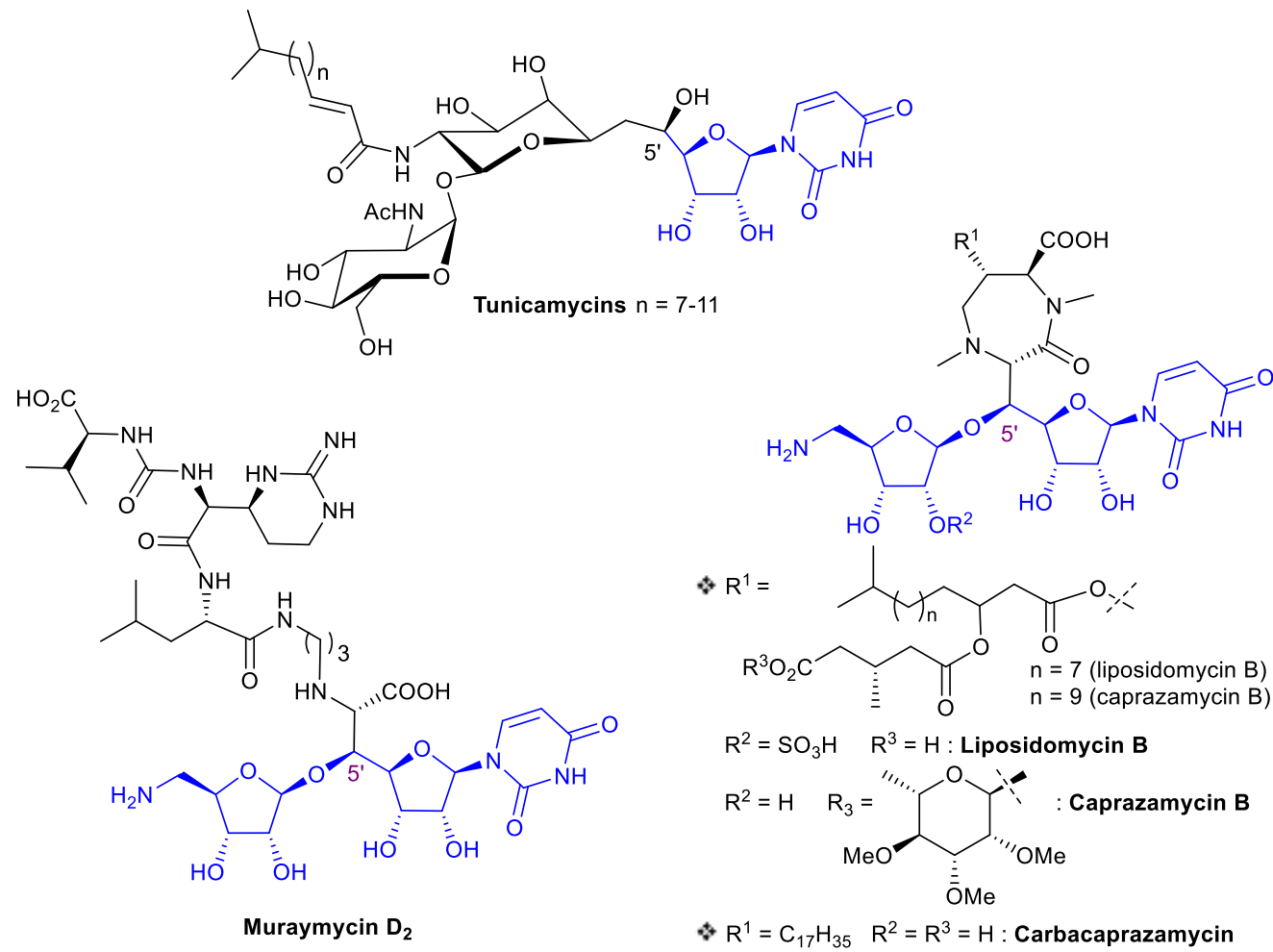

Fig. 1 MraY natural and synthetic inhibitors.

Several 3D structures of MraY have been solved including that of MraY from Aquifex aeolicus in its apoenzyme form (MraYAA, PDB code: $4 J 72),{ }^{23}$ or in complex with different ligands: $\mathrm{MraY}_{\mathrm{AA}}$ with muraymycin D2 (Fig. 1, PDB code: 5CKR), ${ }^{24} \mathrm{MraY}$ from Clostridium boltae with tunicamycin (Fig. 1, PDB: $5 \mathrm{JNQ})^{25}$ and recently of $\mathrm{MraY}_{\mathrm{AA}}$ with carbacaprazamycin (Fig. 1, PDB: 6OYH), capuramycin (PDB: 6OYZ) or 3-hydroxymureidomycin A (PDB: 6OZ6). ${ }^{26}$ Based on the structures of MraY in complex with these nucleoside inhibitors or analogs, Mashalidis et al. published an in-depth comparative study of their 
mode of interaction into the large MraY binding site. ${ }^{26}$ They identified several druggable hot spots (HS) (Fig. 2). As already supposed, ${ }^{24}$ the filling of uridine pocket and the uridine-adjacent pocket, HS1, have been proven to be crucial. The overlay of $\mathrm{MraY}_{\mathrm{AA}}$ bound to five potent inhibitors shows indeed that all of them share many interactions with both uridine and HS1 pockets. Furthermore, other interactions are specific to each inhibitor that induces different plasticity of the protein leading to a more "opened" conformation of the active site in 5CKR or a "closed" one in 6OYH. For instance, while muraymycin D2 in 5CKR structure targets HS2 as an additional area exposed to the solvent, carbacaprazamycin alkyl chain expands widely in the long hydrophobic groove HS4 in 6OYH structure. Moreover, this HS4 pocket has been predicted to be the binding site of the lipid carrier substrate $\mathrm{C}_{55}-\mathrm{P} .{ }^{26}$

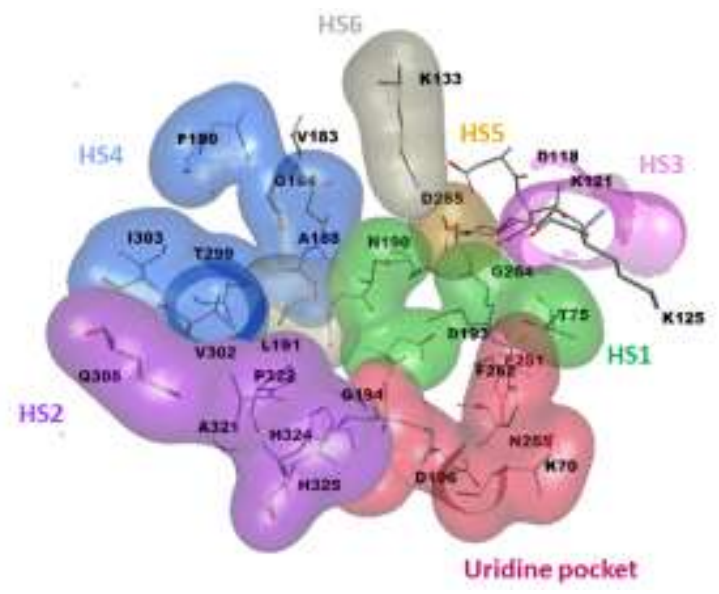

Fig. 2 Schematic representation of hot spots (HSs) of MraY inhibition according to Seok-Yong Lee et al. ${ }^{26}$

We previously described the synthesis of MraY transferase inhibitors such as simplified liposidomycins analogs built on a diazepanone central core ${ }^{27}$ or analogs of muraymycins in which the chemical diversity was introduced on an aminoribosyl uridine scaffold through a triazole ${ }^{28}$ or a methylene triazole linker. ${ }^{29}$ Docking of these triazole-containing inhibitors in the $\mathrm{MraY}_{\mathrm{AA}}$ active site in either 5 CKR or $60 Y$ structural models revealed that the triazole linker established no significant interaction with any amino acids of the active site. However, depending on the structural model, the alkyl chain filled either the HS2 area in the 5CKR model or the HS4 pocket in the 60YH model. In the continuity of this work, we became interested in developing the synthesis of new MraY inhibitors displaying a simple urea motif as a spacer between the aminoribosyl uridine scaffold and various linear or aromatic substituents (Fig. 3). Indeed, this scaffold is known to be endowed with MraY inhibitory activity. ${ }^{18}$ Interestingly, docking experiments in either 5CKR or 60YH models showed that, on the contrary to the triazole linker, the urea moiety was able to generate new hydrogen bonds with amino acids of $\mathrm{MraY}_{\mathrm{AA}}$ active site. Indeed, in 5CKR model, the urea moiety established a hydrogen bond with $\mathrm{N} 255$ and in 6OYH model with $\mathrm{H} 325$. We hypothesized that these interactions could be susceptible to improve the activity of the resulting urea-containing inhibitors as compared to that of the previously synthetized triazole ones. ${ }^{29}$ Compounds with various simple alkyl chains were targeted to fill either HS4 pocket or HS2 area, or branched compounds susceptible to occupy both areas. A few inhibitors containing one or several aromatic moieties were also envisaged since they could generate stabilizing $\pi$-stacking interactions with amino acids residues of the active site.

In this paper, we present the results of our investigations concerning the synthesis, the biological evaluation and the molecular modeling studies of these urea-containing inhibitors and discuss the effect of the nature of the chain on the activity. 


\section{Results and discussion}

\section{Chemical synthesis}

Methods generally used for the formation of unsymmetrical ureas ${ }^{30}$ involve the condensation of $N, N^{\prime}$-carbonyldiimidazole ${ }^{31,32}$ carbamates, $^{33}$ or isocyanates ${ }^{34,35}$ on a primary amine. These methods present the advantage of being compatible with the presence of protected sugars. However, isocyanates are relatively unstable and their formation involves the use of toxic reagents such as phosgene or its precursor triphosgene. The amine can also be carbonylated with carbon monoxide in the presence of transition metal catalysts. ${ }^{36,37,38}$ Other routes utilizing carbon dioxide $\left(\mathrm{CO}_{2}\right)$ as the source of the carbonyl moiety have also been developed. ${ }^{39}$ Recent one-pot sequential threecomponent reactions of cyclic 2-diazo-1,3-diketones, carbodiimides, and 1,2-dihaloethanes have also been carried out. ${ }^{40}$

Due to the elaborated structure of the targeted MraY inhibitors, we chose classical smooth conditions for the synthesis of unsymmetrical urea involving first the condensation of carbonyl diimidazole on primary amines bearing the various chosen chains followed by the subsequent condensation on the resulting $\mathrm{N}$-substituted- $\mathrm{H} \mathrm{H}$-imidazole-1-carboxamide of the azidoribosyl uridine substituted at the $5^{\prime}$ position by a methylene amine. Accordingly, the retrosynthesis we designed towards the targeted inhibitors (Fig. 3 ) relies on condensation of the primary amine $\mathbf{A}$ onto various activated amides $\mathbf{B}$, derived from the corresponding alkylamines $\mathbf{C}$. Amine $\mathbf{A}$ could arise from the selective deprotection of the amino group located at $\mathbf{C}-\mathbf{6}^{\prime}$ of compound $\mathbf{D}$. Fully protected compound D would be prepared by diastereoselective glycosylation between the $\mathrm{N}$-protected aminoalcohol $\mathbf{F}$ and a ribosyl donor $\mathbf{E}$, activated as a fluoride in anomeric position and suitably protected at $\mathbf{C}-5$. Alcohol $\mathbf{F}$ should be easily obtained by nucleophilic opening of epoxide $\mathbf{G}$ accessible in a few steps from uridine. ${ }^{28}$

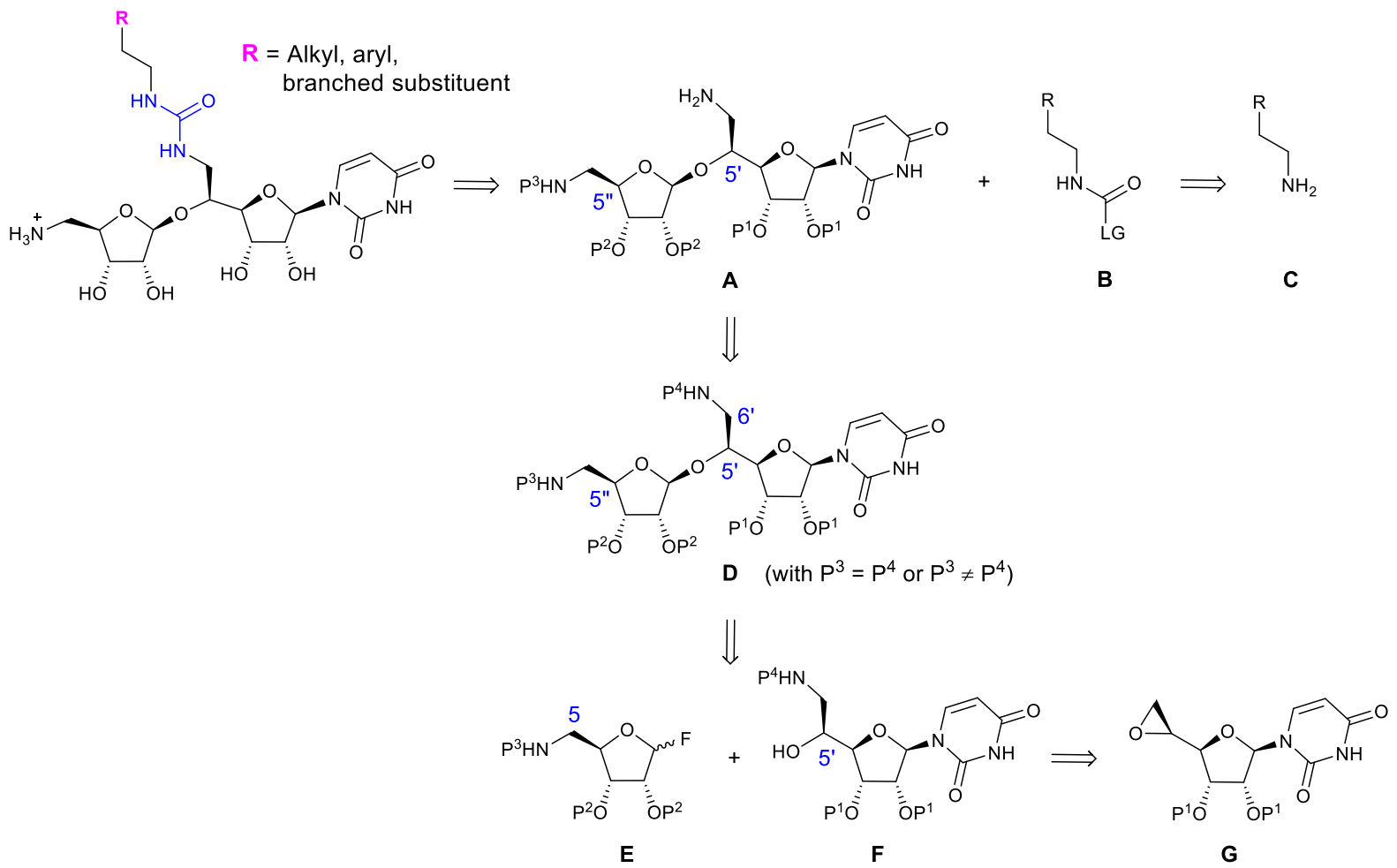

Fig. 3 Structure of the targeted inhibitors and their retrosynthetic analysis. 
Protecting groups on compound $\mathbf{D}$ need to be carefully selected. We previously showed the importance of using TBS groups for $\mathrm{P}^{1}$ to guarantee an efficient and diastereoselective synthesis of epoxide $\mathbf{G}$ with a $5^{\prime}(S)$ configuration. ${ }^{41}$ Moreover, Matsuda et al. demonstrated that a 3-pentylidene protecting group at $\mathrm{P}^{2}$ ensures a good beta selectivity for the glycosylation step. ${ }^{42}$ Concerning $\mathrm{P}^{3}$ and $\mathrm{P}^{4}$, they could be either identical, which would led us to experiment a challenging selective deprotection of the $\mathrm{C}^{-5^{\prime}}$ protection over the $\mathrm{C}-5^{\prime}$ ' one, or different. In the latter case, an orthogonal strategy would be required to remove $\mathrm{P}^{4}$ while $\mathrm{P}^{1}, \mathrm{P}^{2}$ and $\mathrm{P}^{3}$ remain intact. In either case, as compound $\mathbf{F}$ would result from the nucleophilic opening of epoxide $\mathbf{G},{ }^{41}$ and $\mathbf{E}$ would arise from the nucleophilic displacement of a leaving group at $\mathrm{C}-5,{ }^{42}$ we chose to focus exclusively on nucleophiles able to behave as masked primary amine such as $N$-phthalimide and azide anions. Both azide and phthalimide groups have been shown to be perfectly compatible with the oxonium ion. ${ }^{29}$

As we already described the synthesis of azide $1\left(\mathrm{P}^{3}=\mathrm{N}_{3}\right.$ and $\left.\mathrm{P}^{4}=\mathrm{NPhth}\right),{ }^{29}$ we first studied the reduction of compound $\mathbf{1}$ into the corresponding amine $\mathbf{2}$ (Scheme 1 ).
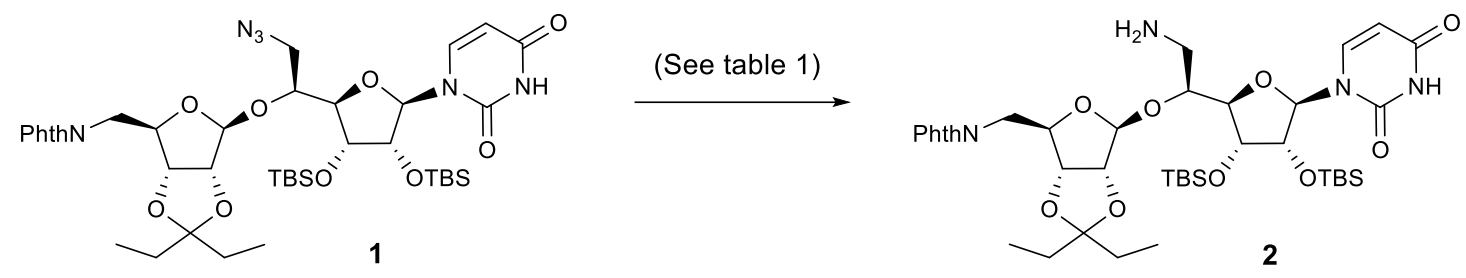

Scheme 1 Attempts to synthetize amine 2.

We first considered the use of Staudinger reduction conditions (Table 1). Compound $\mathbf{2}$ has been isolated in 20\% yield along with two unexpected products: diamide 3 and imine $\mathbf{4}$ in $38 \%$ and $28 \%$ yield respectively (Table 1 , entry 1 ). Diamide 3 could arise from the intramolecular condensation of the newly formed primary amine on one of the phthalimide carbonyl groups, whereas imine $\mathbf{4}$ could directly result from an intramolecular aza-Wittig reaction between a carbonyl group of the phthalimide and the reactive iminophosphorane $\mathbf{5}$, before its hydrolysis into amine $\mathbf{2}$ (Scheme 2). In order to promote the hydrolysis of iminophosphorane $\mathbf{5}$, one equivalent of acetic acid was added but, surprisingly, only the imine 4 was isolated and in a poor $6 \%$ yield (Table 1, entry 2). To avoid the formation of iminophosphorane 5 , we then turned our attention to hydrogenolysis conditions. The use of palladium on charcoal (1 equiv.) in methanol led to the formation of diamide 3 (Table 1, entry 3 ), indicating that, in these conditions, the intramolecular cyclization step is favored since no trace of amine 2 was isolated. No reaction was observed by using Pearlman's catalyst in $\mathrm{MeOH}$ (Table 1, entry 4). 

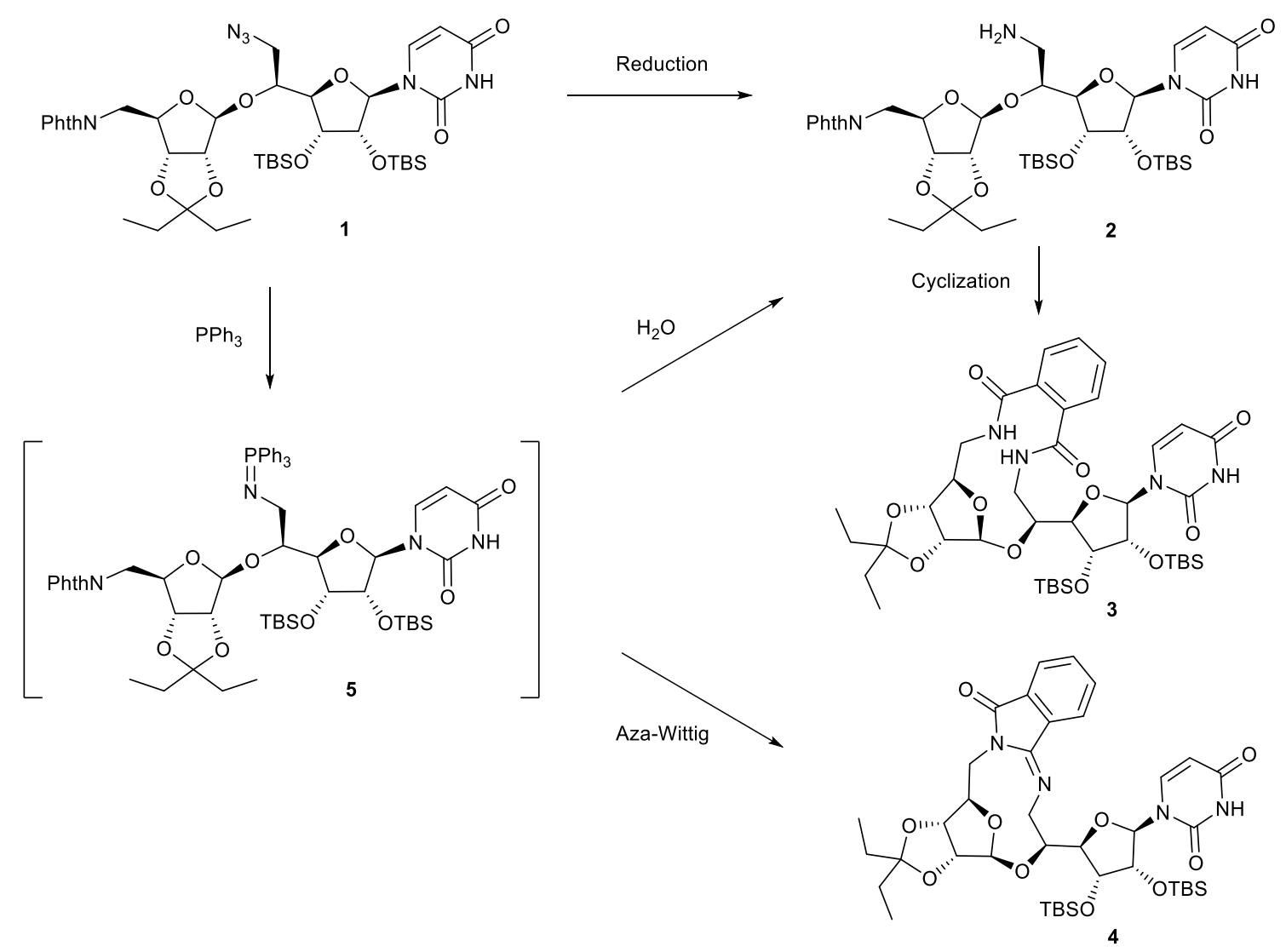

Scheme 2 Hypothesis for the formation of diamide 3 and imine 4.

Table 1 Reduction of azide 1. Reagents and conditions.

\begin{tabular}{ccccc}
\hline Entry & Conditions & $\mathbf{2}$ & $\mathbf{3}$ & $\mathbf{4}$ \\
& $\mathrm{PPh}_{3}, \mathrm{H}_{2} \mathrm{O} / \mathrm{THF}$ & 20 & 38 & 28 \\
\hline $\mathbf{1}$ & $\mathrm{PPh}_{3}, \mathrm{AcOH}, \mathrm{H}_{2} \mathrm{O} / \mathrm{THF}$ & - & - & 6 \\
$\mathbf{2}$ & $\mathrm{H}_{2}, \mathrm{Pd} / \mathrm{C}, \mathrm{MeOH}$ & - & 60 & - \\
$\mathbf{3}$ & $\mathrm{H}_{2}, \mathrm{Pd}(\mathrm{OH})_{2}, \mathrm{MeOH}$ & - & - & - \\
$\mathbf{4}$ &
\end{tabular}

This preliminary study shows that the preparation of the primary amine $\mathbf{2}$ from compound $\mathbf{1}\left(\mathrm{P}^{3}=\right.$ $\mathrm{N}_{3}$ and $\mathrm{P}^{4}=\mathrm{NPhth}$ ) is challenging since it is prone to spontaneous intramolecular addition onto a carbonyl group of the phthalimide. Therefore, we decided to switch the position of both masked amines $\left(P^{3}=\right.$ NPhth and $\left.P^{4}=N_{3}\right)$.

We thus tackled the synthesis of phthalimidoalcohol 8 (Scheme 3). As previously reported, ${ }^{41}$ epoxide 7 can be prepared by the diasteroselective epoxidation of alkene 6 by an excess of $m$ CPBA in DCM. However, we showed that the use of a 2/1 mixture of DCM and phosphate buffer, $\mathrm{pH} 7$ as a solvent ${ }^{43}$ facilitated the elimination of $m C P B A$ in excess and $m$-chlorobenzoic acid during work-up, when the reaction was carried out on gramme scale. In these conditions, the mixture of diastereomeric epoxides is sufficiently clean to be engaged without any purification in the subsequent nucleophilic opening by potassium phthalimide in DMF. Purification of the resulting 75/25 diastereomeric mixture of $5^{\prime}(S) / 5^{\prime}(R)$-phtalimidoalcohol led to pure $5^{\prime}(S)$-phthalimidoalcohol 8 that was isolated in $64 \%$ yield over two steps. 


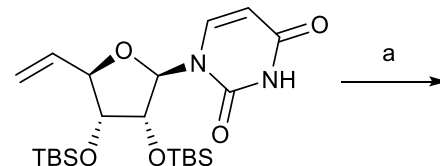

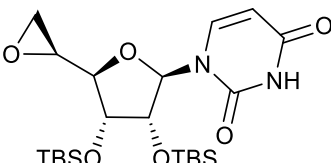

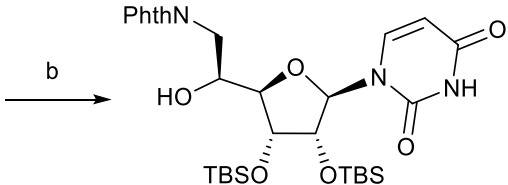

Scheme 3 Synthesis of phtalimidoalcohol 8. Reagents and conditions: (a) $m C P B A, 4$ equiv., $\mathrm{CH}_{2} \mathrm{Cl}_{2} / \mathrm{Phosphate}$ buffer $\mathrm{pH} 7$ : 2/1, $30^{\circ} \mathrm{C}, 16$ h, r.d.: 75/25; (b) PhthNK, DMF, r.t., 12 h, 64\% over two steps.

We next turned our attention to the glycosylation of the $5^{\prime}(S)$-phthalimidoalcohol 8 with the 5azidoribosyl fluoride $9^{42}$ as a glycosyl donor. The reaction was performed in the presence of an excess of boron trifluoride in a perfectly dry environment (Scheme 4) and we were pleased to obtain compound 10 , as a single $\beta$ isomer, in a $64 \%$ yield. This result shows that the steric hindrance due to the phthalimido group at C-6' does not prevent the glycosylation of the secondary alcohol under these conditions. We first attempted to cleave the phthalimido group by methylamine in methanol, however, the( reaction revealed troublesome and dependent on the source of methylamine. Finally, the use of hydrazine in methanol at room temperature led to the formation of amine $\mathbf{1 1}$ in quantitative yield.

To assess the impact on biological activity of the introduction of a urea linker, the azido group of amine $\mathbf{1 1}$ was reduced under Staudinger conditions with polymer-supported triphenylphosphine and deprotection of the alcohol functions was carried out in a 4/1 cold mixture of trifluoroacetic acid/water (Scheme 4). After purification by C18-reverse phase chromatography, the reference compound $\mathbf{1 2}$ was isolated in a modest $15 \%$ yield.<smiles>CCC1(CC)OC2C(F)OC(CN)C2O1</smiles>

9<smiles>NCC(OC1OC(CN)[C@@H](O)[C@H]1O)C1OC(n2ccc(=O)[nH]c2=O)[C@H](O)[C@H]1O</smiles>

12

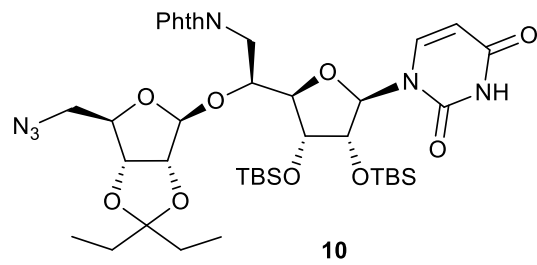

b

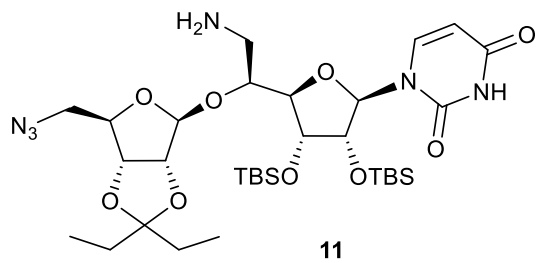

Scheme 4 Synthesis of amine 11 and reference compound 12. Reagents and conditions: (a) BF $\mathrm{BFtO}_{3} \cdot \mathrm{EtO}_{2}$ M.S. $4 \AA$, $\mathrm{CH}_{2} \mathrm{Cl}_{2},-78{ }^{\circ} \mathrm{C}$ to r.t., 16 h, $64 \%$; (b) $\mathrm{NH}_{2} \mathrm{NH}_{2} \cdot \mathrm{H}_{2} \mathrm{O}, \mathrm{MeOH}$, r.t., $12 \mathrm{~h}, 100 \%$; (c) $\mathrm{PPh}_{3}$ resin, $\mathrm{THF} / \mathrm{H}_{2} \mathrm{O} 85 / 15$, r.t., 48 h; (d) $\mathrm{TFA} / \mathrm{H}_{2} \mathrm{O} 4 / 1,0^{\circ} \mathrm{C}$, r.t., $16 \mathrm{~h}, 15 \%$.

Amine $\mathbf{1 1}$ in hand, we undertook the synthesis of various primary amines which were selected on the one hand, according to our previous results ${ }^{29}$ showing the best activity of compounds with long hydrophobic chains, and on the other hand after careful examination of the crystallographic data of MraY co-crystallized with muraymycin D2 (PDB 5CKR), ${ }^{24}$ and carbacaprazamycin (PDB 6OYH). ${ }^{26}$ In the light of the hots spots (HSs) defined by Seok-Yong Lee et al. ${ }^{26}$ for the inhibition of MraY (Fig. 2), we picked a set of primary hydrophobic amines with linear or branched chains, displaying various chain length, containing or not heterocycles, aromatic moieties, and halogen atoms, in order to maximize 
the occupancy of HS4 and/or HS2. ${ }^{26}$ Among the selected amines, 13a-b and 13f-g were commercially available, while amines $\mathbf{1 3 c}-\mathbf{e}$ and $\mathbf{1 3 h - k}$ were synthesized (Scheme 5).

Amines $13 \mathrm{c}$ and $13 \mathrm{e}$ have been prepared by Staudinger reduction of the corresponding organic azides $\mathbf{1 4 ^ { 2 9 }}$ and $\mathbf{1 5} \mathbf{4}^{44}$ (Scheme 5). Amines $\mathbf{1 3 d , j , k}$, were synthesized through a common intermediate $\mathbf{1 6}$, easily prepared by dimesylation of octanediol followed by the nucleophilic displacement of one mesylate by an azide ion. Then, the remaining mesylate has been substituted by 1-benzhydrylpiperazine, hydroxybenzophenone or di-n-octylamine, to furnish compounds 17,18 and 19 respectively. Subsequent Staudinger reduction of the azido moiety led to the desired amines $\mathbf{1 3 d} \mathbf{d} \mathbf{j}, \mathbf{k}$ in very good yields. Compounds $\mathbf{2 0}$ and $\mathbf{2 1}$ were, for their part, derived from $\mathrm{N}$-(2bromoethyl)phthalimide by nucleophilic substitution of the bromine atom either by the di- $n$ octylamine or by the 1-[5-(trifluoromethyl)pyrid-2-yl]piperazine. Cleavage of the phthalimide moiety with hydrazine provided amines $13 \mathrm{~h}$ and $13 \mathrm{i}$ in quantitative yield.

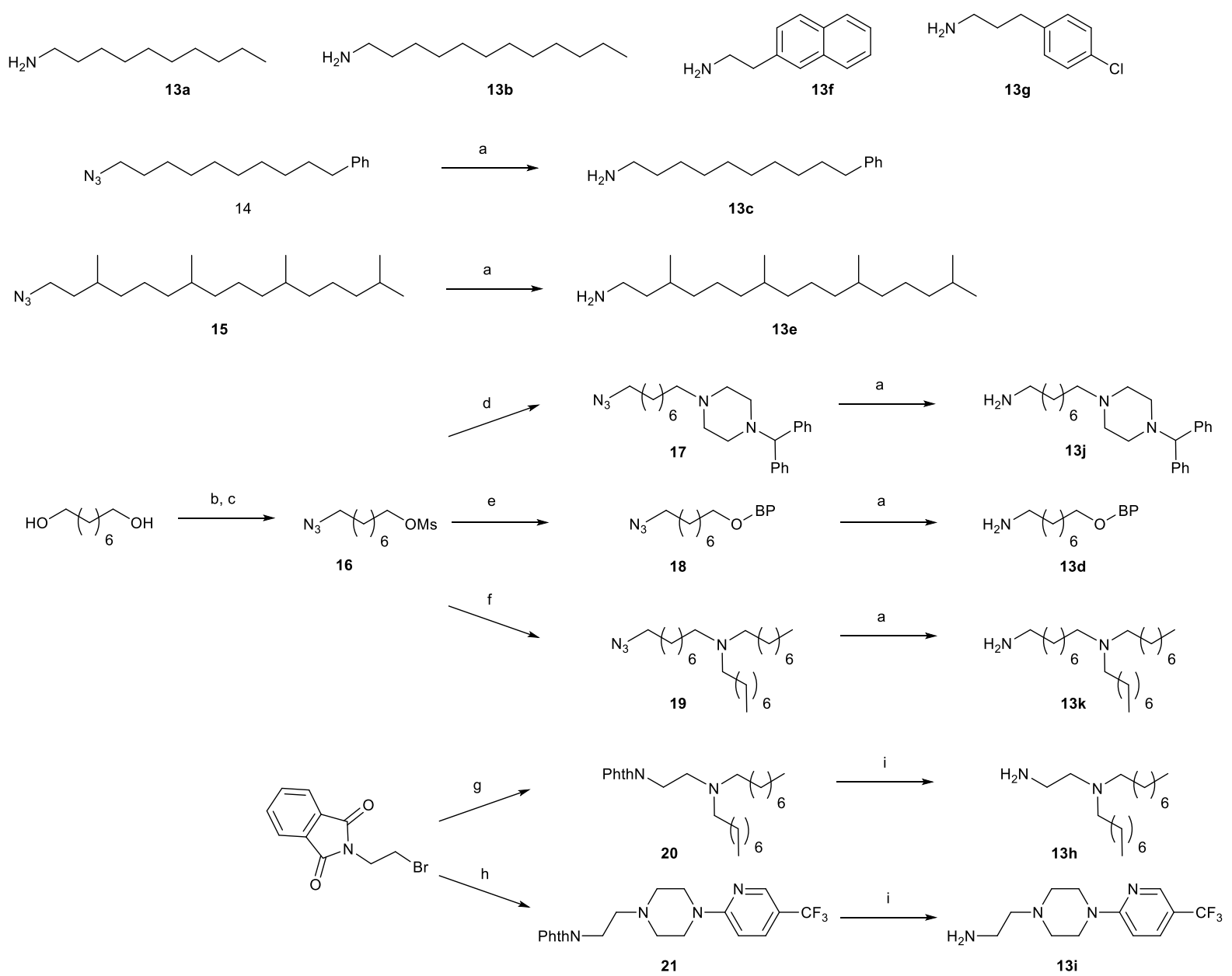

Scheme 5 Structure of selected primary amines $13 a-k$ and synthesis of $13 \mathrm{c}-\mathbf{e}$ and $\mathbf{1 3 h}-\mathbf{k}$. Reagents and conditions: (a) $\mathrm{PPh}_{3}, \mathrm{THF} / \mathrm{H}_{2} \mathrm{O}$, r.t., 12 h; (b) $\mathrm{MsCl}, \mathrm{TEA}, \mathrm{CH}_{2} \mathrm{Cl}_{2}, 0{ }^{\circ} \mathrm{C}, 30 \mathrm{~min}$, r.t., $12 \mathrm{~h}, 98 \%$ except for $13 \mathrm{c}$ : $92 \%$; (c) $\mathrm{NaN}_{3}$, DMF, $90{ }^{\circ} \mathrm{C}, 18 \mathrm{~h}, 48 \%$; (d) 1-Benzhydryl-piperazine, TEA, $\mathrm{CH}_{3} \mathrm{CN}$, reflux, $16 \mathrm{~h}, 88 \%$; (e) 4-hydroxybenzophenone (BP-4-OH), $\mathrm{K}_{2} \mathrm{CO}_{3}, \mathrm{KI}, \mathrm{DMF}, 80{ }^{\circ} \mathrm{C}, 16 \mathrm{~h}, 87 \%$; (f) di-n-octylamine, TEA, $\mathrm{CH}_{3} \mathrm{CN}$, reflux, $16 \mathrm{~h}, 59 \%$; (g) di-noctylamine, $\mathrm{K}_{2} \mathrm{CO}_{3}, \mathrm{CH}_{3} \mathrm{CN}$, reflux, $16 \mathrm{~h}$, 74\%; (h) 1-[5-(trifluoromethyl)pyrid-2-yl]piperazine, $\mathrm{K}_{2} \mathrm{CO}_{3}, \mathrm{CH}_{3} \mathrm{CN}$, reflux, $16 \mathrm{~h}, 90 \%$; (i) $\mathrm{NH}_{2} \mathrm{NH}_{2} \cdot \mathrm{H}_{2} \mathrm{O}$, EtOH, $80{ }^{\circ} \mathrm{C}, 12 \mathrm{~h}, 100 \%$.

We then undertook the synthesis of the targeted unsymmetrical $N, N^{\prime}$-disubstituted ureas (Scheme 6). Amines 13a-k were submitted to 1,1'-carbonyldiimidazole. The substitution of a first imidazole ring was completed at $0^{\circ} \mathrm{C}$ in dichloromethane in the presence of triethylamine to furnish the 
corresponding $1 \mathrm{H}$-imidazole-1-carboxamides 22a-k. The nucleophilic displacement of the second imidazole ring by a default of amine 11 was then achieved at $30^{\circ} \mathrm{C}$. This one-pot procedure gave ureas 23a-k in 40-76\% yield (Table 2). Finally, compounds 23a-k were reduced under Staudinger conditions using polymer-supported triphenylphosphine to optimize the intermediate amine purification step. Deprotection of alcohols was then performed in a cold $4 / 1$ mixture of trifluoroacetic acid/water. The targeted compounds 24a-k were isolated as their free amine in 41 to $76 \%$ yield after flash chromatographic purification on silica gel (Table 2).

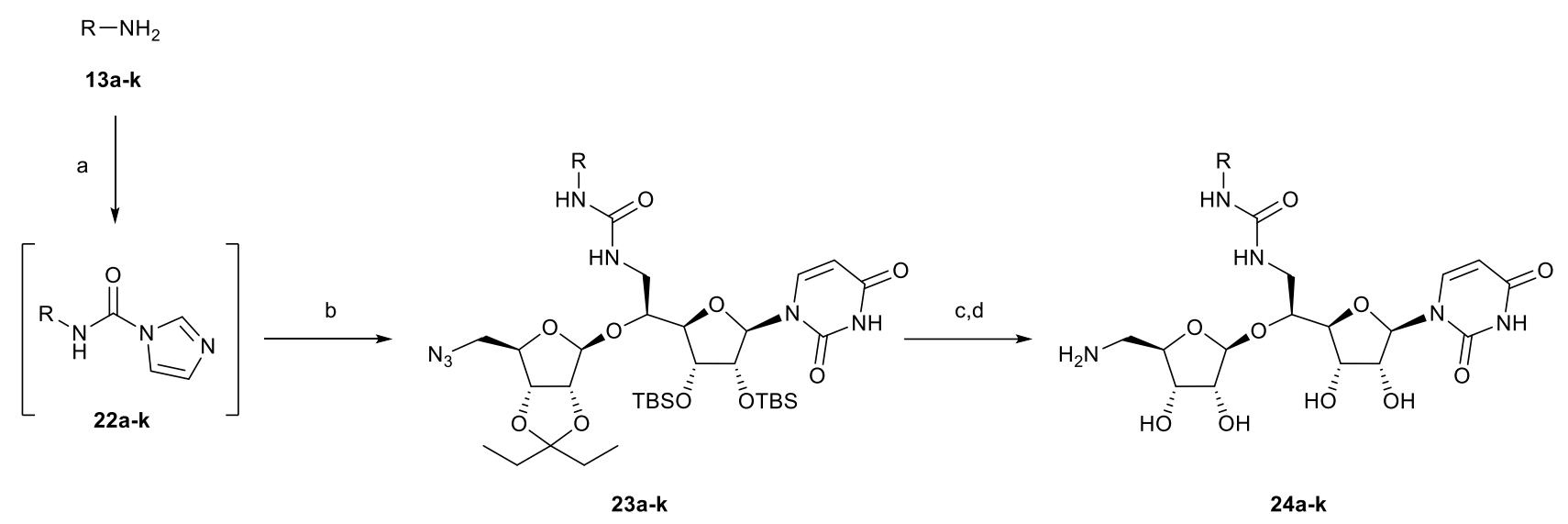

Scheme 6 Synthesis of urea targeted compounds 24a-k. Reagents and conditions: (a) Amine 13a-k, TEA, CDI, $\mathrm{CH}_{2} \mathrm{Cl}_{2}, 0{ }^{\circ} \mathrm{C}$, r.t., $3 \mathrm{~h}$; (b) amine 11, $30{ }^{\circ} \mathrm{C}, 16$ h; (c) $\mathrm{PS}-\mathrm{PPh}_{3}, \mathrm{THF} / \mathrm{H}_{2} \mathrm{O}$ 85/15, r.t., 48 h; (d) $\mathrm{TFA} / \mathrm{H}_{2} \mathrm{O} 4: 1,0^{\circ} \mathrm{C}$, r.t., $16 \mathrm{~h}$.

Table $\mathbf{2}$ Isolated yields for the synthesis of compounds $\mathbf{2 3 a - k}$ and $\mathbf{2 4 a - k}$.

\begin{tabular}{|c|c|c|c|}
\hline Amine & $\mathrm{R}$ & $\begin{array}{c}23 \\
\text { Yield (\%) }\end{array}$ & $\begin{array}{c}24 \\
\text { Yield (\%) }\end{array}$ \\
\hline $13 a$ & $-\left(\mathrm{CH}_{2}\right)_{9} \mathrm{CH}_{3}$ & 73 & 42 \\
\hline $13 b$ & $-\left(\mathrm{CH}_{2}\right)_{11} \mathrm{CH}_{3}$ & 76 & 63 \\
\hline $13 c$ & $-\left(\mathrm{CH}_{2}\right)_{10} \mathrm{Ph}$ & 66 & 63 \\
\hline $13 d$ & $-\left(\mathrm{CH}_{2}\right)_{8} \mathrm{OBP}$ & 76 & 76 \\
\hline $13 e$ & $-\left(\left(\mathrm{CH}_{2}\right)_{2} \mathrm{CHCH}_{3}\right)_{4} \mathrm{CH}_{3}$ & 40 & 61 \\
\hline $13 f$ & $-\left(\mathrm{CH}_{2}\right)_{2}-2-\mathrm{Naphthyl}$ & 73 & 60 \\
\hline $13 g$ & $-\left(\mathrm{CH}_{2}\right)_{3}-p \mathrm{C}_{6} \mathrm{H}_{4} \mathrm{Cl}$ & 66 & 47 \\
\hline $13 \mathrm{~h}$ & $-\left(\mathrm{CH}_{2}\right)_{2}-\mathrm{N}\left(\left(\mathrm{CH}_{2}\right)_{8}\right)_{2}$ & 47 & 76 \\
\hline $13 \mathbf{i}$ & $-\left(\mathrm{CH}_{2}\right)_{2}-\mathrm{PZ}-2-\mathrm{Pyr}-\mathrm{CF}_{3}{ }^{a}$ & 45 & 60 \\
\hline 13j & $-\left(\mathrm{CH}_{2}\right)_{8}-\mathrm{PZ}-\mathrm{CH}(\mathrm{Ph})_{2}^{a}$ & 47 & 67 \\
\hline $13 k$ & $-\left(\mathrm{CH}_{2}\right)_{8}-\mathrm{N}\left(\left(\mathrm{CH}_{2}\right)_{8}\right)_{2}$ & 57 & 41 \\
\hline
\end{tabular}

${ }^{a} \mathrm{PZ}$ stands for piperazine

\section{Biological evaluation}

The inhibitory activity of the synthesized $N, N^{\prime}$-disubstituted ureas 24a-k, and their unprotected amino precursor 12, was evaluated on MraY transferase purified from Aquifex aeolicus ( $\mathrm{MraY}_{\mathrm{AA}}$ ) prepared as previously described by Chung et al. ${ }^{23}$ Their activity was compared to the inhibitory activity of compounds $\mathbf{2 5}$ and $\mathbf{2 6}$ containing a $\mathbf{N}$ - or a $\mathrm{C}$-triazole linker (Fig. 4) which we previously synthesized ${ }^{29}$ (Table 3). Commercially available tunicamycin from Streptomyces $s p$. was used as a positive control in the test. 


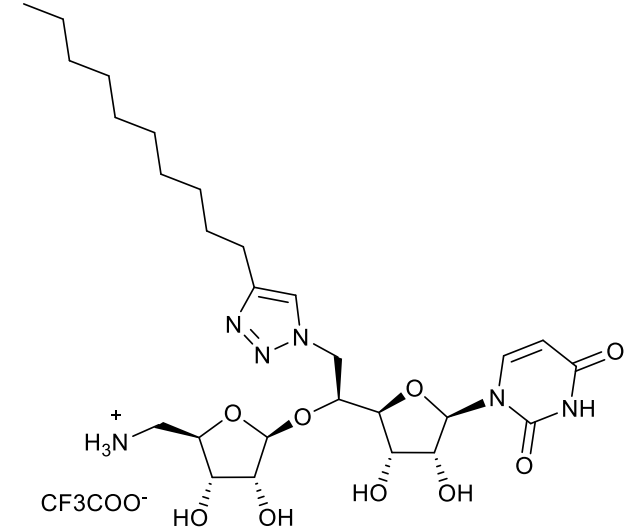

25

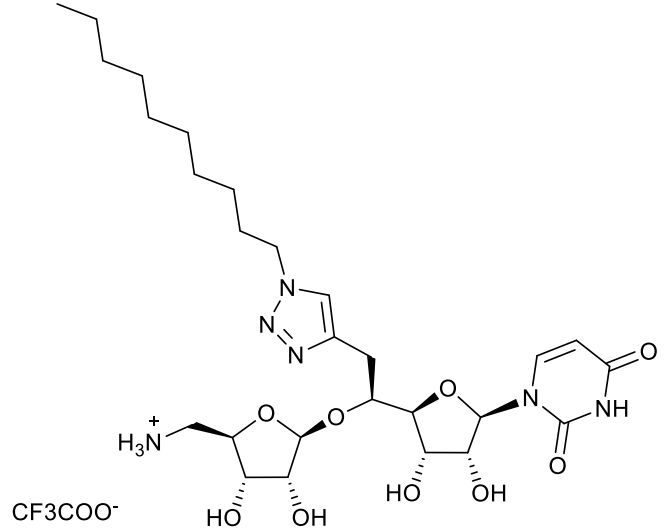

26

Fig. 4 Structure of triazole-containing MraY inhibitors we previously synthesized.

Table 3 Inhibitory activity of compounds 24a-k against MraYAA

\begin{tabular}{|c|c|c|}
\hline Compound & $\mathrm{R}$ & $\mathrm{IC}_{50}(\mu \mathrm{M})^{\mathrm{c}}$ \\
\hline Tunicamycin & & $0.026 \pm 0.00$ \\
\hline 12 & & $50.30 \pm 3.27$ \\
\hline 25 & $\begin{array}{c}-\left(\mathrm{CH}_{2}\right)_{9} \mathrm{CH}_{3}(\mathrm{~N} \text {-linked } \\
\text { triazole })\end{array}$ & $2.14 \pm 0.09$ \\
\hline 26 & $\begin{array}{c}-\left(\mathrm{CH}_{2}\right)_{9} \mathrm{CH}_{3}(\mathrm{C} \text {-linked } \\
\text { triazole })\end{array}$ & $3.74 \pm 0.11$ \\
\hline $24 a$ & $-\left(\mathrm{CH}_{2}\right)_{9} \mathrm{CH}_{3}$ & $1.93 \pm 0.13$ \\
\hline $24 b$ & $-\left(\mathrm{CH}_{2}\right)_{11} \mathrm{CH}_{3}$ & $3.00 \pm 0.07$ \\
\hline $24 c$ & $-\left(\mathrm{CH}_{2}\right)_{10} \mathrm{Ph}$ & $2.84 \pm 0.05$ \\
\hline 24d & $-\left(\mathrm{CH}_{2}\right)_{8} \mathrm{OBP}^{a}$ & $3.54 \pm 0.17$ \\
\hline $24 e$ & $-\left(\left(\mathrm{CH}_{2}\right)_{2} \mathrm{CHCH}_{3}\right)_{4} \mathrm{CH}_{3}$ & $40.38 \pm 0.0001$ \\
\hline $24 f$ & - $\left(\mathrm{CH}_{2}\right)_{2}-2-\mathrm{Naphthyl}$ & $3.30 \pm 0.07$ \\
\hline $24 \mathrm{~g}$ & $-\left(\mathrm{CH}_{2}\right)_{3}-p \mathrm{C}_{6} \mathrm{H}_{4} \mathrm{Cl}$ & $3.49 \pm 0.09$ \\
\hline $24 h$ & $-\left(\mathrm{CH}_{2}\right)_{2}-\mathrm{N}\left(\left(\mathrm{CH}_{2}\right)_{8}\right)_{2}$ & $6.24 \pm 0.39$ \\
\hline $24 i$ & $-\left(\mathrm{CH}_{2}\right)_{2}-\mathrm{PZ}-2-\mathrm{Pyr}-\mathrm{CF}_{3}{ }^{b}$ & $6.20 \pm 0.57$ \\
\hline $24 j$ & $-\left(\mathrm{CH}_{2}\right)_{8}-\mathrm{PZ}-\mathrm{CH}(\mathrm{Ph})_{2}^{b}$ & $16.74 \pm 0.78$ \\
\hline $24 k$ & $-\left(\mathrm{CH}_{2}\right)_{8}-\mathrm{N}\left(\left(\mathrm{CH}_{2}\right)_{8}\right)_{2}$ & $14.64 \pm 0.40$ \\
\hline
\end{tabular}

${ }^{a} \mathrm{BP}=$ benzophenone ${ }^{b} \mathrm{PZ}$ stands for piperazine. ${ }^{c}$ Experiments were performed in triplicate and each experiment was repeated at least twice except for Tunicamycin as a control that was tested twice.

As shown in Table 3, all the tested compounds 24a-k are relevant inhibitors of the enzymatic activity catalyzed by the transferase $\mathrm{MraY}_{\mathrm{AA}}$ with $\mathrm{IC}_{50}$ ranging from 1.9 to $16.7 \mu \mathrm{M}$ for 10 compounds out of 11 . Moreover, these results support that the functionalisation of the amine at $\mathrm{C6}^{\prime}$ of the $5^{\prime} \mathrm{S}$-aminomethylaminoribosyl-uridine is beneficial to the inhibitory activity since all compounds present an $\mathrm{IC}_{50}$ lower than that of the reference amine $\mathbf{1 2}$ which displayed an $\mathrm{IC}_{50}$ of $c a .50 \mu \mathrm{M}$. The most active compound revealed to be compound 24a with a linear decyl chain, exhibiting an $\mathrm{IC}_{50}$ equal to $1.9 \mu \mathrm{M}$. However, it was observed that increasing the chain length does not permit to improve the inhibitory activity since compound $\mathbf{2 4 b}$ with a dodecyl chain is slightly less active than compound $\mathbf{2 4 a}$. The presence of an aromatic moiety at the terminal position of a long alkyl chain such as a phenyl group (24c) or a benzophenone moiety (24d) is not detrimental to inhibitory activity suggesting that the positioning of 
these inhibitors within the active site is compatible with the presence of these bulky groups. Compounds with shorter alkyl chain bearing aromatic substituents such as 2-naphthyl (24f) or $p$-Clphenyl (24g) also behave as good inhibitors of $\mathrm{MraY}_{\mathrm{AA}}$ activity. On the contrary, the presence of a hindered highly ramified alkyl chain (24e) led to a significant loss of inhibitory activity. It is also noteworthy to mention that the substitution by a tertiary amine is better tolerated if it is positioned at 2 bonds from the urea moiety $(\mathbf{2 4 h}, \mathbf{2 4} \mathbf{i})$ than if it is located at 8 bonds of the urea (24j, 24k). Finally, even if the most active compound 24a with a decyl chain revealed to be the best inhibitor in this series with a urea linker, the activity of the best compounds remains in the same order as that of the previously synthesized triazole compounds $\mathbf{2 5}$ and $\mathbf{2 6}$. This result shows that the interaction of the urea linker with MraY active site is not sufficient to drastically improve the activity of the urea inhibitors as compared to that of the triazole containing ones.

\section{Determination of MIC (minimal inhibitory concentration)}

The antibacterial activity of compounds $\mathbf{2 4 a - k}$ was evaluated and the data are presented in Table 4. Several Gram-negative (E. coli ATCC 8730, C. freundii ATCC8090 and P. aeruginosa ATCC 27853) and Gram-positive pathogenic bacterial strains (S. aureus ATCC 25923, E. faecium ATCC 19434) were selected, including a methicillin resistant strain (S. aureus MRSA ATCC 43300). Piperacillin and vancomycin were used as positive control in the tests. Negative controls were also used such as the reference amine $\mathbf{1 2}$ and a control urea $\mathbf{2 7}$ (Fig. 5, see experimental section for its synthesis). Furthermore, lipophilic amines lacking the aminoribosyl uridine part of the inhibitors such as $N^{1}, N^{1}$ dioctylethane-1,2-diamine $13 \mathrm{~h}$ and $N^{1}, N^{1}$-dioctyloctane-1,2-diamine $13 \mathbf{k}$ were also tested.<smiles>CCCCNC(=O)NCCN(CC)CC(C)C</smiles>

Fig. 5 Structure of compound 27.

Table 4 Antibacterial activity of compounds $\mathbf{2 4 a - k}$ and reference compounds.

\begin{tabular}{|c|c|c|c|c|c|c|c|c|}
\hline \multirow{3}{*}{ Compound } & \multirow{3}{*}{$\mathbf{R}$} & \multirow{3}{*}{$\begin{array}{c}{ }^{I C_{50}} \\
(\mu \mathrm{M})\end{array}$} & \multicolumn{6}{|c|}{$\mathrm{MIC}(\mu \mathrm{g} / \mathrm{mL})$} \\
\hline & & & \multicolumn{3}{|c|}{ Gram-negative } & \multicolumn{3}{|c|}{ Gram-positive } \\
\hline & & & 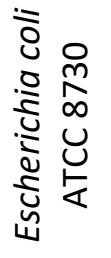 & 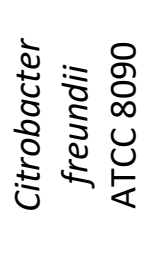 & 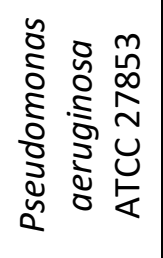 & 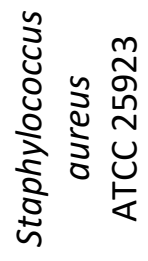 & 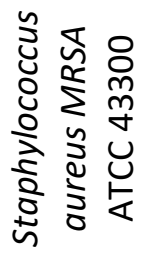 & 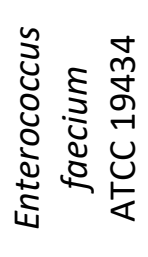 \\
\hline Piperacillin & & & 4 & 4 & 8 & 4 & $>128$ & 4 \\
\hline Vancomycin & & & - & - & - & 1 & 1 & 0.5 \\
\hline 12 & & 50.3 & $>128$ & $>128$ & $>128$ & $>128$ & $>128$ & $>128$ \\
\hline $13 h^{c}$ & & & 8 & 8 & 64 & 8 & 8 & 8 \\
\hline $13 k$ & & & 32 & 32 & 128 & 8 & 32 & 8 \\
\hline $20^{c}$ & & & $>128$ & $>128$ & $>128$ & $>128$ & $>128$ & $>128$ \\
\hline
\end{tabular}




\begin{tabular}{|c|c|c|c|c|c|c|c|c|}
\hline $\mathbf{2 5}$ & $-\left(\mathrm{CH}_{2}\right)_{9} \mathrm{CH}_{3}$ (N-linked) & 2.1 & $>128$ & $>128$ & $>128$ & $\mathbf{1 2 8}$ & $\mathbf{6 4}$ & $>128$ \\
\hline $\mathbf{2 6}$ & $-\left(\mathrm{CH}_{2}\right)_{9} \mathrm{CH}_{3}$ (C-linked) & 3.7 & $>128$ & $>128$ & $\mathbf{1 2 8}$ & $\mathbf{1 6}$ & $\mathbf{6 4}$ & $>128$ \\
\hline $\mathbf{2 7}$ & & & $>128$ & $>128$ & $>128$ & 8 & 8 & 8 \\
\hline $\mathbf{2 4 a}$ & $-\left(\mathrm{CH}_{2}\right)_{9} \mathrm{CH}_{3}$ & 1.9 & $>128$ & $>128$ & $>128$ & $>128$ & $>128$ & $>128$ \\
\hline $\mathbf{2 4 b}$ & $-\left(\mathrm{CH}_{2}\right)_{11} \mathrm{CH}_{3}$ & 3.0 & $>128$ & $>128$ & $>128$ & $\mathbf{6 4}$ & $\mathbf{6 4}$ & $\mathbf{6 4}$ \\
\hline $\mathbf{2 4 c}$ & $-\left(\mathrm{CH}_{2}\right)_{10} \mathrm{Ph}$ & 2.8 & $>128$ & $>128$ & $>128$ & $>128$ & $>128$ & $>128$ \\
\hline $\mathbf{2 4 d}$ & $-\left(\mathrm{CH}_{2}\right)_{8} \mathrm{OBP}{ }^{a}$ & 3.5 & $>128$ & $>128$ & $>128$ & $>128$ & $>128$ & $>128$ \\
\hline $\mathbf{2 4 e}$ & $-\left(\left(\mathrm{CH}_{2}\right)_{2} \mathrm{CHCH}_{3}\right)_{4} \mathrm{CH}_{3}$ & 40.0 & $>128$ & $>128$ & $>128$ & $\mathbf{3 2}$ & $\mathbf{3 2}$ & $\mathbf{3 2}$ \\
\hline $\mathbf{2 4 f}$ & $-\left(\mathrm{CH}_{2}\right)_{2}-2-\mathrm{Naphthyl}$ & 3.3 & $>128$ & $>128$ & $>128$ & $>128$ & $>128$ & $>128$ \\
\hline $\mathbf{2 4 g}$ & $-\left(\mathrm{CH}_{2}\right)_{3}-p \mathrm{C}_{6} \mathrm{H}_{4} \mathrm{Cl}$ & 3.5 & $>128$ & $>128$ & $>128$ & $>128$ & $>128$ & $>128$ \\
\hline $\mathbf{2 4 h}$ & $-\left(\mathrm{CH}_{2}\right)_{2}-\mathrm{N}\left(\left(\mathrm{CH}_{2}\right)_{8}\right)_{2}$ & 6.2 & 128 & 128 & 64 & 32 & 32 & 32 \\
\hline $\mathbf{2 4 i}$ & $-\left(\mathrm{CH}_{2}\right)_{2}-\mathrm{PZ}-2-\mathrm{Pyr}_{2}-\mathrm{CF}_{3}{ }^{b}$ & 6.2 & $>128$ & $>128$ & $>128$ & $>128$ & $>128$ & $>128$ \\
\hline $\mathbf{2 4 j}$ & $-\left(\mathrm{CH}_{2}\right)_{8}-\mathrm{PZ}-\mathrm{CH}^{2}(\mathrm{Ph})_{2}{ }^{b}$ & 16.7 & $>128$ & $>128$ & $>128$ & $\mathbf{3 2}$ & $\mathbf{3 2}$ & $\mathbf{3 2}$ \\
\hline $\mathbf{2 4 k}$ & $-\left(\mathrm{CH}_{2}\right)_{8}-\mathrm{N}\left(\left(\mathrm{CH}_{2}\right)_{8}\right)_{2}$ & 14.6 & $\mathbf{1 2 8}$ & $\mathbf{1 2 8}$ & $\mathbf{1 2 8}$ & $\mathbf{8}$ & $\mathbf{8}$ & $\mathbf{8}$ \\
\hline
\end{tabular}

The reference amine 12 shows no antibacterial activity (MIC $>128 \mu \mathrm{g} / \mathrm{mL}$ ) neither for Gram-positive nor for Gram-negative bacteria. The substitution of the primary amine, which gives rise to compounds 24a-k is required to the antimicrobial activity (Table 4). In the light of the results, the $\mathbf{2 4}$ series could be divided into three groups of molecules: the first one including 24a, 24c-d, 24f-g and 24i, showing not antibacterial activity at all, with MICs values higher than $128 \mu \mathrm{g} / \mathrm{mL}$ against the six bacterial species selected as representative of pathogen bacterial diversity. The second group includes $\mathbf{2 4} \mathbf{h}$ and $\mathbf{2 4 k}$, active against both Gram negative and positive bacteria, with MIC $\leq 128 \mu \mathrm{g} / \mathrm{mL}$ and finally the third group regrouping compounds $\mathbf{2 4 b} \mathbf{2} \mathbf{2 4}$ and $\mathbf{2 4}$ j, active only against Gram positive bacteria.

The compounds of the first group will likely never reach their cytoplasmic targets because they would be unable to cross the cytoplasmic membrane, even if they could penetrate into the periplasm of Gram-negative bacteria. Within this group, the $\mathrm{N}$-substitution could be classified as linear (24a with a decyl chain) and/or linear containing an aromatic ring (24c-d, 24f-g and 24i). Instead, compounds included in the second and third groups contain either only one linear C12 alkyl chain (24b), or branched side chains $(\mathbf{2 4 e}, \mathbf{2 4} \mathbf{h}, \mathbf{2 4 j}, \mathbf{2 4 k})$. It might be accordingly rule that a linear side chain of, at least, 12 carbon atoms, or a branched substituent should be anchored to compound $\mathbf{1 2}$ to show antibacterial activity. Within the second group, $\mathbf{2 4} \mathbf{h}$ and $\mathbf{2 4} \mathbf{k}$ compounds could be compared in terms of biological activity since the only difference between them is the arm linking $\left(\mathrm{N}-\left(\mathrm{CH}_{2}\right)_{7}-\mathrm{CH}_{3}\right)$ head, containing 2 and $8 \mathrm{C}$ atoms respectively. The higher MIC for Gram negative could be explained by the outer membrane characteristic of this group of bacteria.

The MICs of $13 \mathrm{~h}$ and $\mathbf{1 3 k}$, which are the precursors of the side chains that substitute the reference scaffold to give $\mathbf{2 4} \mathbf{h}$ and $\mathbf{2 4} \mathbf{k}$ derivatives respectively, were also determined. Both showed antibacterial activity but $13 \mathrm{~h}$ has a general better action (Table 4). This is not an unexpected result, considering that 13h and 13k could act as cationic detergents. It is known that the latter compounds possess bactericidal activity linked to their ability to destabilize lipid bilayers. Compound $\mathbf{2 0}$, the precursor of compound $13 \mathrm{~h}$, lacking a positive charge and that cannot act as a cationic detergent, shows no antibacterial activity (MIC $>128 \mu \mathrm{g} / \mathrm{mL}$ ) neither for Gram-positive nor for Gram-negative bacteria. When the antibacterial activities of $\mathbf{1 3 h}$ and $\mathbf{1 3 k}$ are compared to those obtained for their corresponding final molecules (24h and $\mathbf{2 4 k}$ ), their antibacterial activities were modified: $\mathbf{2 4} \mathbf{h}$ and $\mathbf{2 4 k}$ now exhibit poor activities $(64-128 \mu \mathrm{g} / \mathrm{mL})$ against Gram-negative bacteria compared to the good 
values obtained for their precursor $(8-32 \mu \mathrm{g} / \mathrm{mL}$, except for one strain). Concerning activities against Gram-positive bacteria, $\mathbf{2 4} \mathbf{h}$ and $\mathbf{2 4 k}$ remain very active. However, $\mathbf{2 4 k}$ is now more active than $\mathbf{2 4} \mathbf{h}$, which is the opposite what is observed for $\mathbf{1 3 h}$ and $\mathbf{1 3 k}$.

The triazole derivatives $\mathbf{2 5}$ and $\mathbf{2 6}$ do not show antibacterial activity towards Gram negative bacteria (MIC $\geq 128 \mu \mathrm{g} / \mathrm{mL}$ ), while showing variable activity against Gram positive bacteria. In a general way, $\mathrm{N}$-linked derivatives seem more active. Compared to compound $\mathbf{1 3 h}$, the reference urea $\mathbf{2 7}$ displaying the same branched chain, but lacking the aminoribosyl uridine scaffold, is not active against the selected Gram-negative bacteria. The molecule remains active against the Gram-positive bacteria $(\mathrm{MIC}=8 \mu \mathrm{g} / \mathrm{mL})$.

To resume, all compounds derived from molecule $\mathbf{1 2}$ and displaying branched chains show inhibitory activity against the selected Gram-positive species, but they seem not able to cross the outer membrane of Gram negative species. Interestingly, the obtained antibacterial activities for these relatively simple compounds are comparable to that reported for muraymycins, that are natural MraY inhibitors but with much more complex structures. ${ }^{45}$

\section{Docking Studies}

To rationalize the described structure activity relationship study, docking experiments were performed on the recently published structures of $\mathrm{MraY}_{\mathrm{AA}}$ complexed with muraymycin D2 (PDB code $5 \mathrm{CKR})^{24}$ and carbacaprazamycin (PDB code $\left.60 \mathrm{YH}\right)^{26}$ based on structural similarities between our compounds and co-crystal ligands. Docking results revealed two binding modes for active compounds. In 5CKR model, the more active compounds (24a-c, 24f-g, 1. $9 \mu \mathrm{M}<\mathrm{IC}_{50}<3.5 \mu \mathrm{M}$ ) exhibited a binding mode similar to muraymycin D2 (Fig. 6), except compound 24d for which no clear binding mode was observed due to steric constraints. The uracil part of these active compounds interacts with conserved residues K70, D196, N255 and F262 in the uridine pocket. The amino group of the 5-aminoribosyl moiety was stabilized by an electrostatic interaction with the highly conserved residue D265 in the uridine-adjacent pocket. The ribosyl moiety of the aminoribosyl established an H-bonding network with T75, D118 and K121. Moreover, the urea established hydrogen bond with H325 for compounds (24a-c, 24f-g). The aliphatic chain occupied the HS2 area in the active site of MraY establishing hydrophobic interactions with V302 and $\mathrm{A} 321$. Compound $\mathbf{2 4 i}\left(\mathrm{IC}_{50}=6.2 \mu \mathrm{M}\right)$ adopted the two possible binding modes previously described with the chain either in HS2 area or HS4 pocket, while the chain of the polymethylated inactive compound $24 \mathrm{e}$ did not fill properly any area. For compounds $\mathbf{2 4 h}$ and 24k ( $\left(\mathrm{C}_{50}=6.2\right.$ and $14.6 \mu \mathrm{M}$, respectively), location of the chains in HS2 area and HS4 pocket revealed to be detrimental to the optimized positioning of the aminoribosyl uridine moiety. For compound $\mathbf{2 4 \mathbf { j }}$ $\left(I C_{50}=16.7 \mu \mathrm{M}\right)$, the positioning of the chain was not favorable due to the steric hindrance of the aromatic moieties. 

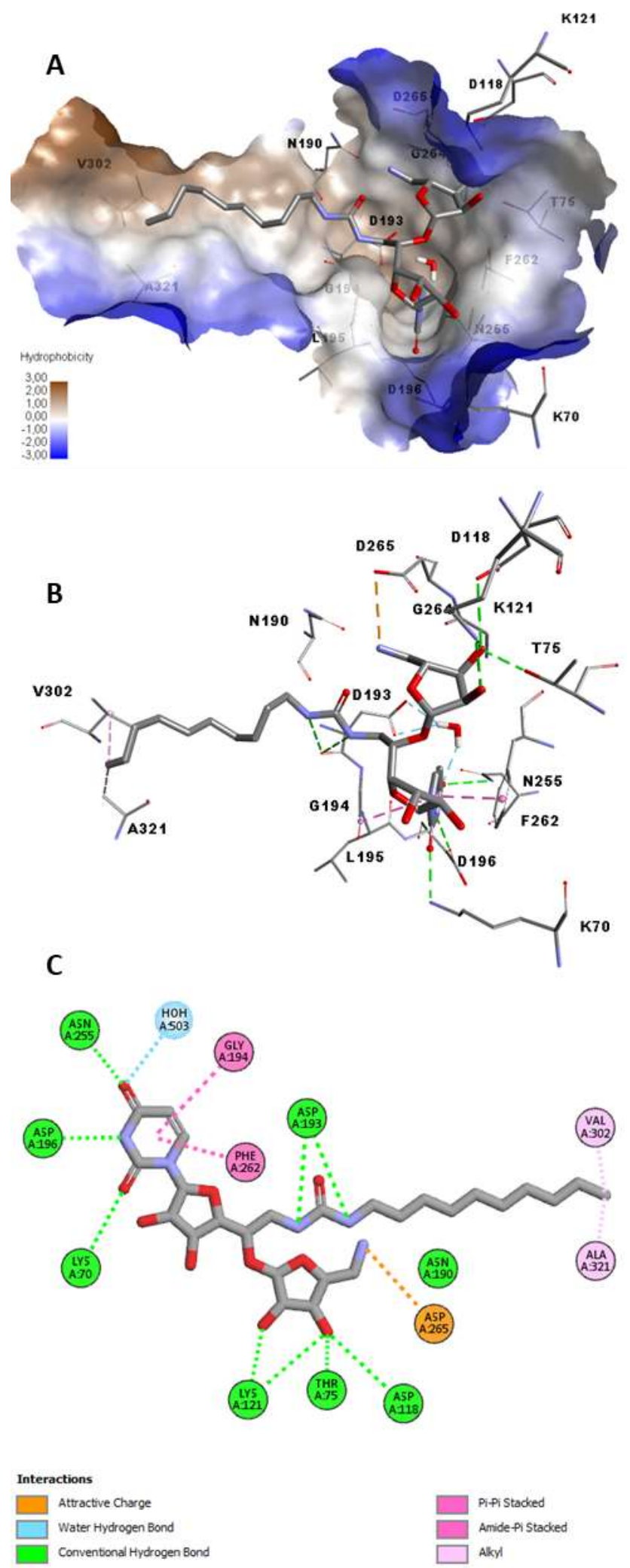

Fig. 6 Docking pose of compound 24a with the active site of MraY PDB (code 5CKR). (A) The hydrophobic surface is rendered as brown and hydrophilic surface as blue. Ligand and residues are shown in stick mode. (B) Non covalent bond interactions between the ligand $\mathbf{2 4 a}$ and residues of the active site are indicated by colored dashed lines: hydrophobic interactions (magenta), electrostatic interactions (orange), water hydrogen bond (blue) and conventional hydrogen bond (green). (C) 2D diagram of interactions between ligand 24a and MraY. The hydrogen atoms were omitted for clarity. 
In the 6OYH structure, the more active compounds 24a-d, 24f, 24i $\left(1.9 \mu \mathrm{M}<\mathrm{IC}_{50}<6.5 \mu \mathrm{M}\right)$ adopted a binding mode similar to that of carbacaprazamycin, ${ }^{26}$ except compound $24 \mathrm{~g}$ for which no clear binding mode was observed. For these compounds, the aliphatic tail fitted into the long hydrophobic groove HS4 surrounded by protein residues F180, G184, A188, L191, T299, V302, 1303. The urea interacts with backbone and side chain atoms of N190. The interactions of the uracil part with residues D196, N255 and F262 of the uridine pocket were preserved. An electrostatic interaction between amine of the aminoribosyl moiety and D193 was observed (Fig. 7). The inactive polymethylated compound $\mathbf{2 4 e}$ was not able to properly fit in HS4 pocket. For the branched compound 24h $\left(\mathrm{IC}_{50}=6.2 \mu \mathrm{M}\right)$, both alkyl chains occupied both hydrophobic areas HS4 and HS2, however, the electrostatic interactions with D193 were lost. For the other branched compounds $\mathbf{2 4} \mathbf{j}$ and $\mathbf{2 4 k}$ no favorable binding mode was observed.

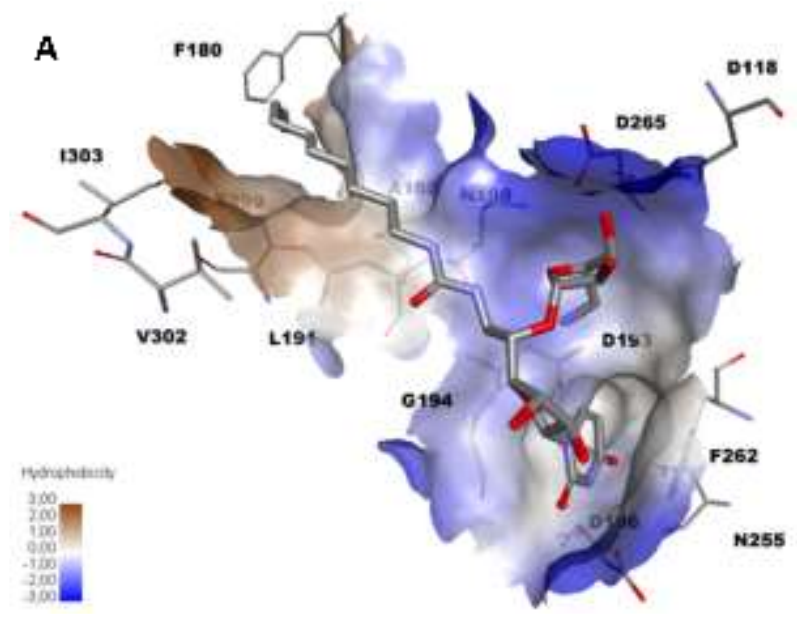

B

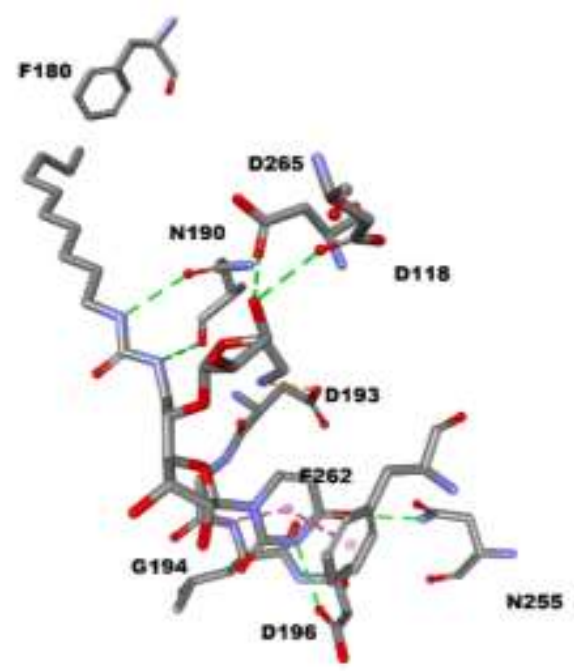

Fig. 7 Docking pose of compound 24a within the active site of Mray PDB (code 6OYH. (A) The hydrophobic surface is rendered as brown and hydrophilic surface as blue. Ligand and residues are shown in stick mode. (B) Noncovalent bond interactions between the ligand $\mathbf{2 4 a}$ and residues of the active site are indicated by colored dashed lines: hydrophobic interactions (magenta), electrostatic interactions (orange) and conventional hydrogen bond (green). The hydrogen atoms were omitted for clarity. 
To conclude, our docking experiments showed that the positioning of the aminoribosyl uridine moiety was similar for the more active compounds in an opened or closed MraY active site. However, to discriminate between the two predicted locations (HS4 or HS2) of the urea chain, we undertook a molecular dynamics study.

\section{Molecular Dynamics}

Starting from the docking results in MraY (PDB code 6OYH), we ran 50ns molecular dynamic (MD) simulations to evaluate the stability of compound 24a within the MraY active site in a membrane environment. MD simulations of the MraY-carbacaprazamycin complex were also performed as a trajectory control. Analysis of the trajectory of $60 \mathrm{YH}$-carbacaprazamycin complex revealed that the global position of the ligand was preserved along the simulation with little variation in the RMSD curve (Fig. 8) keeping key interactions identified in the crystal structure (PDB: 6OYH). However, compound 24a exhibited a significant positional modification (Fig. 8). The simulation suggests weak character of the $\mathrm{H}$-bond interactions between the urea moiety and N290. More stable H-bonds were retrieved between the urea moiety oxygen and histidine residues $\mathrm{H} 324$ and $\mathrm{H} 325$ leading to the flip of the alkyl chain toward the HS2 area of MraY (d1, d2, Table 5). The position of the uracil moiety was conserved forming persistent $\mathrm{H}$-bonds with D196, N255 and K70 (d3-d7, Table 5). Another important $\pi-\pi$ stacked interaction was observed between the uracil ring and F262. The amino group of the amino ribosyl moiety losts interaction with D193 carboxylate in favor of D265 carboxylate during the last part of the simulation (32-50ns). The ligand adopted a binding mode similar to that previously observed in 5CKR (Fig. 9).

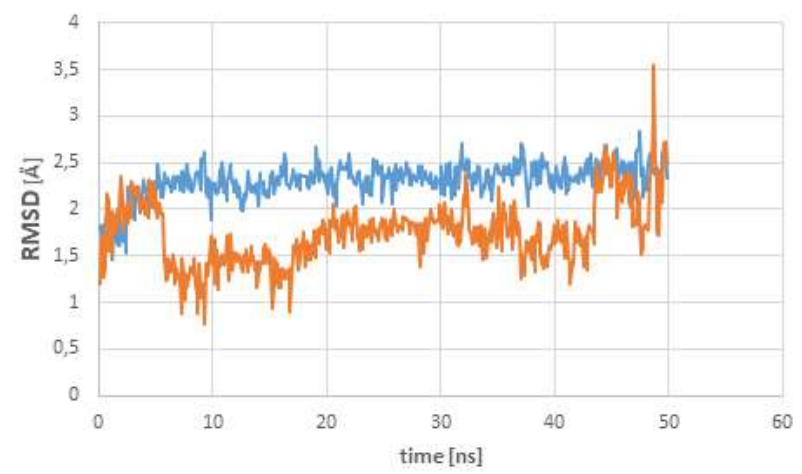

Fig. 8 RMSD plot of the ligands atoms. MraY-24a complex (orange), MraY-carbacaprazamycin complex (blue).

Table 5 Length distribution hydrogen-bond retrieved between 24a and relevant amino acids in the active site of MraY.

\begin{tabular}{|c|c|c|}
\hline $\begin{array}{c}\text { H-bond } \\
\text { (dx) }^{a}\end{array}$ & $\begin{array}{c}\text { H-bond length } \\
\text { (Å) }\end{array}$ & $\begin{array}{c}\text { Conformations } \\
\text { (\%) }\end{array}$ \\
\hline $\mathrm{d} 1$ & $<2$ & 10 \\
& $2-3$ & 18 \\
\hline $\mathrm{d} 2$ & $<2$ & 16 \\
& $2-2.5$ & 21 \\
& $2.5-3$ & 12 \\
\hline $\mathrm{d} 3$ & $<3$ & 51 \\
\hline $\mathrm{d} 4$ & $<2$ & 92 \\
& $2-2.5$ & \\
\hline
\end{tabular}




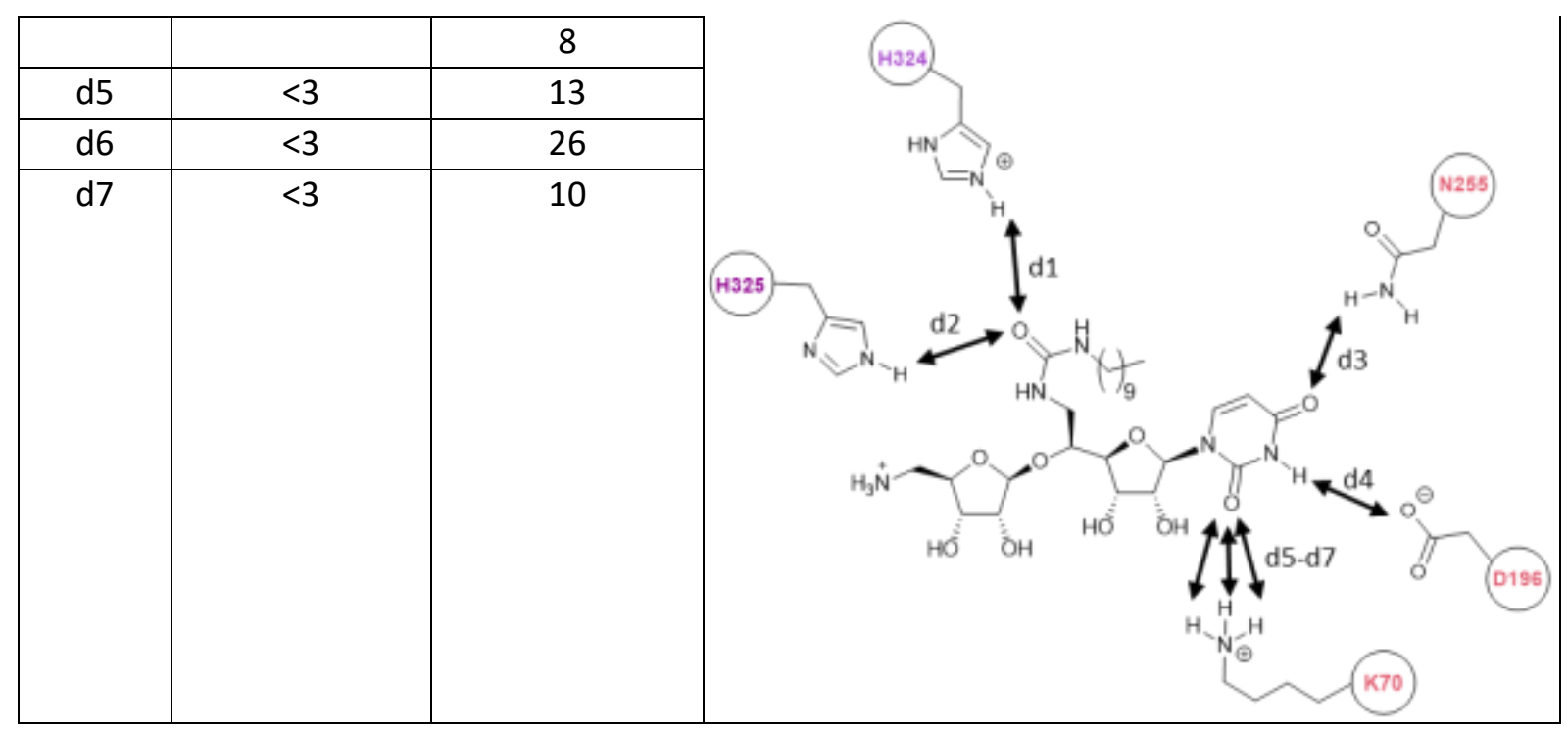

${ }^{a}$ : Name of the distance.

A

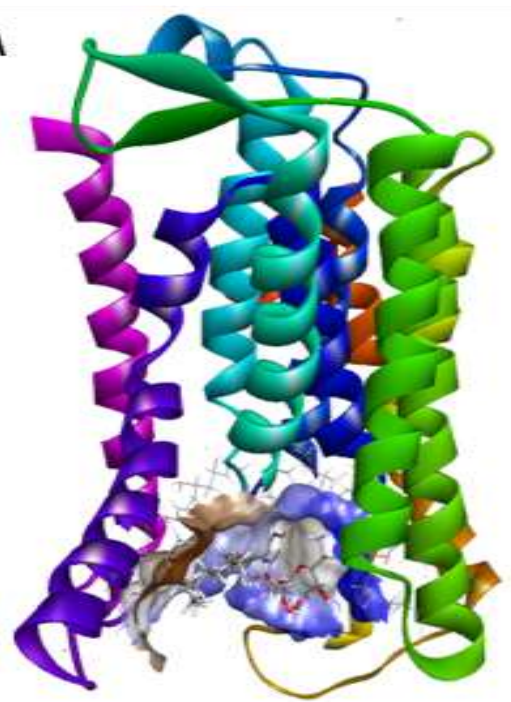

B

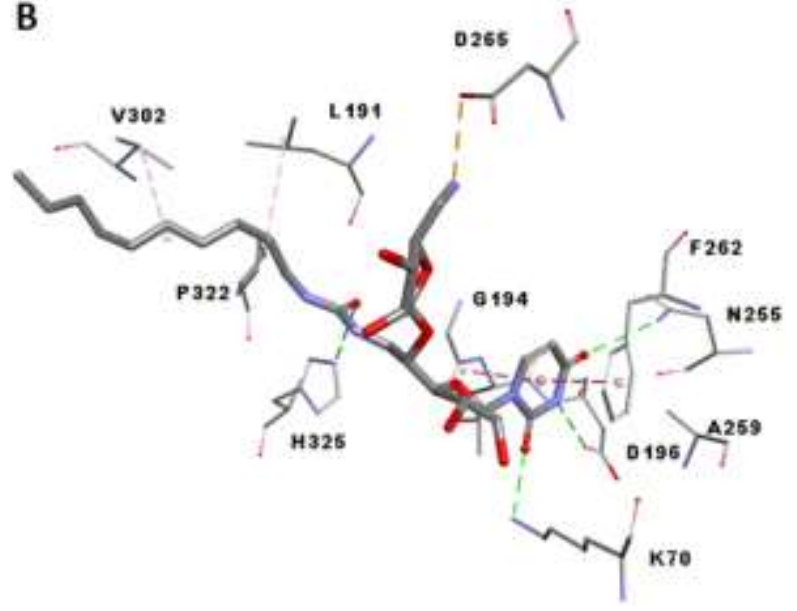

Fig. 9 Representative snapshot of the ligand binding mode in MraY (PDB 6OYH) during MD simulation. (A) Protein is represented as a ribbon diagram. The hydrophobic surface is rendered as brown and hydrophilic surface as blue. Ligand and residues are shown in stick mode. (B) Non-covalent bond interactions between the ligand 24a and residues of the active site are indicated by colored dashed lines: hydrophobic interactions (magenta), electrostatic interaction (orange) and conventional hydrogen bond (green). The hydrogen atoms were omitted for clarity.

The results of molecular dynamics show that the anchoring of the aminoribosyl uridine moiety is preserved during the simulation. However, the urea linker failed to maintain the alkyl chain in the long hydrophobic HS4 groove embedded in the membrane, as it is observed for the alkyl chain of carbacaprazamycin. The resulting less favorable hydrophobic interactions of the alkyl chain with an area exposed to the solvent (HS2), probably justify the more modest activity of the urea inhibitors as compared to that of carbacaprazamycin.

\section{Conclusion}


We report the synthesis of inhibitors of the bacterial transferase MraY displaying a 5'-methylene urea-substituted aminoribosyl uridine structure. Their convergent synthesis was achieved from activated amides and a conveniently protected azidoribosyl uridine bearing an aminomethyl group at C $-5^{\prime}$. To ensure the preparation of this key intermediate in high yield, we showed that the choice of masked amines on the uridine and ribose derived building blocks, respectively, was crucial. The biological activity of the 11 resulting compounds was evaluated in vitro on purified $\mathrm{MraY}_{\mathrm{AA}}$ and in cellulo on different Gram-positive and Gram-negative bacterial strains and was compared to that of triazole-containing compounds we previously synthetized and to other reference compounds. Ten out of eleven compounds revealed $\mathrm{MraY}$ inhibition with $\mathrm{IC}_{50}$ ranging from $1.9 \mu \mathrm{M}$ to $16.7 \mu \mathrm{M}$. Compound 24a with a decyl chain revealed to be the best inhibitor in this series. However, its activity remains similar to that of the most active triazole compound 25. Four compounds exhibited antibacterial activity against three Gram-positive species including methicillin resistant Staphylococcus aureus (MRSA) and Enterococcus faecium human pathogens with MIC ranging from 8 to $32 \mu \mathrm{g} / \mathrm{mL}$. Both ureas $\mathbf{2 4 h}$ and $\mathbf{2 4 k}$ with a tertiary amine revealed antibacterial activity on tested Gram-positive bacteria (32 and $8 \mu \mathrm{g} / \mathrm{mL}$, respectively) and a slight activity on Gram-negative strains (64-128 $\mu \mathrm{g} / \mathrm{mL}$ ).

Docking results showed two binding modes for active compounds. In the first one, ligands exhibited a binding mode similar to muraymycin D2 in 5CKR while in the second binding mode, the alkyl chain fits into a long hydrophobic groove, as observed for carbacaprazamycin in 6OYH. The stability of the ligand 24a within the MraY active site in 60YH structural model was evaluated in a membrane environment by 50 ns molecular dynamics and showed that compound 24a exhibited a significant positional modification to adopt a binding mode similar to that observed in 5CKR structural model resulting in less favorable interactions that probably justify the lower activity of urea containing inhibitors as compared to carbacaprazamycin. The results also show that the interaction of the urea moiety with the active site was not sufficient to drastically improve the activity of the urea inhibitors as compared to the triazole ones.

\section{Experimental}

\section{General Experimental Methods}

\section{Chemical synthesis}

When needed, reactions were carried out under an argon atmosphere. They were monitored by thinlayer chromatography with precoated silica on aluminium foil. Flash chromatography was performed with silica gel $60(40-63 \mu \mathrm{m})$; the solvent systems are given in v/v. Spectroscopic ${ }^{1} \mathrm{H}$ and ${ }^{13} \mathrm{C} \mathrm{NMR}, \mathrm{MS}$ and/or analytical data were obtained using chromatographically homogeneous samples. ${ }^{1} \mathrm{H}$ NMR (500 $\mathrm{MHz}$ ) and ${ }^{13} \mathrm{C}$ NMR (125 MHz) spectra were recorded in $\mathrm{CDCl}_{3}$ unless otherwise indicated. Chemical shifts $(\delta)$ are reported in ppm and coupling constants are given in $\mathrm{Hz}$. For each compound, detailed peak assignments have been made according to COSY, HSQC and HMBC experiments. The numbering of molecules is indicated in the ESI. + Optical rotations were measured with a sodium $(589 \mathrm{~nm})$ lamp at $20{ }^{\circ} \mathrm{C}$. IR spectra were recorded on an FT-IR spectrophotometer and the wavelengths are reported in $\mathrm{cm}^{-1}$. High resolution mass spectra (HRMS) were recorded with a TOF mass analyzer under electrospray ionization (ESI) in positive ionization mode detection, atmospheric pressure chemical ionization or atmospheric pressure photoionization (APPI). 
1",5"-Dideoxy-2", 3"'-O-isopentylidene-5"'-amino-1"'-[2',3'-O-isopropylidene-5'(S)-azidomethyluridinyl]-B-D-ribofuranose 2 . The protected azide 1 (100 mg, $120 \mu \mathrm{mol}, 1$ equiv.) was dissolved in 4 $\mathrm{mL}$ of THF under argon atmosphere. Triphenylphosphine $\left(91.8 \mathrm{mg}, 360 \mu \mathrm{mol}, 3\right.$ equiv.) and pure $\mathrm{H}_{2} \mathrm{O}$ $(1.5 \mathrm{~mL})$ were added to the reaction mixture and stirred overnight at r.t.. The mixture was concentrated in vacuo and then washed with hexane and filtered in order to eliminate the excess of $\mathrm{PPh}_{3}$. The resulting white foam was purified by flash chromatography (DCM/MeOH 95/5 to 9/1) to give the amino product $\mathbf{2}$ (20 mg, 20\% yield) and two side products $\mathbf{3}$ and $\mathbf{4}$ that were isolated in $38 \%$ and $28 \%$ yield, respectively and characterized.

Compound 2: $[\alpha]_{D}-14$ (c 1, $\mathrm{CH}_{2} \mathrm{Cl}_{2}$ ); IR (film): 3726, 3525, 2300, 1700, 1541, 1421, 1362, 1222, 1166, 1092, 903, 864, 840, 781; ${ }^{1} \mathrm{H}$ NMR $87.89-7.86\left(\mathrm{~m}, 2 \mathrm{H}, \mathrm{H}_{11^{\prime \prime}}\right), 7,76\left(\mathrm{~d}, \mathrm{~J}_{\mathrm{H} 6-\mathrm{H} 5}=8.2 \mathrm{~Hz}, 1 \mathrm{H}, \mathrm{H}_{6}\right), 7.77-7.74$ $\left(\mathrm{m}, 2 \mathrm{H}, \mathrm{H}_{12^{\prime \prime}}\right), 6.10\left(\mathrm{~d}, J_{\mathrm{H} 5-\mathrm{H} 6}=8.0 \mathrm{~Hz}, 1 \mathrm{H}, \mathrm{H}_{5}\right), 5.83\left(\mathrm{~d}, J_{\mathrm{H} 1^{\prime}-\mathrm{H} 2^{\prime}}=4.3 \mathrm{~Hz}, 1 \mathrm{H}, \mathrm{H}_{1^{\prime}}\right), 5.22\left(\mathrm{~s}, 1 \mathrm{H}, \mathrm{H}_{1^{\prime \prime}}\right), 4.76$ $\left(\mathrm{d}, J_{\mathrm{H} 2^{\prime \prime}-\mathrm{H} 3^{\prime \prime}}=6.1 \mathrm{~Hz}, 1 \mathrm{H}, \mathrm{H}_{2^{\prime \prime}}\right), 4.64\left(\mathrm{~d}, J_{\mathrm{H} 3^{\prime \prime}-\mathrm{H} 2^{\prime \prime}}=6.1 \mathrm{~Hz}, 1 \mathrm{H}, \mathrm{H}_{3^{\prime \prime}}\right), 4.50\left(\mathrm{dd}, J_{\mathrm{H}^{\prime \prime}-\mathrm{H} 5^{\prime \prime}}=7.7 \mathrm{~Hz}, 1 \mathrm{H}, \mathrm{H}_{4^{\prime \prime}}\right), 4.24$ (dd, $\left.J_{\mathrm{H}^{\prime}-\mathrm{H} 3^{\prime}}=4.7 \mathrm{~Hz}, J_{\mathrm{H} 4^{\prime}-\mathrm{H} 5^{\prime}}=1.4 \mathrm{~Hz}, 1 \mathrm{H}, \mathrm{H}_{4^{\prime}}\right), 4.19\left(\mathrm{t}, J_{\mathrm{H}^{\prime}-\mathrm{H} 3^{\prime}}=J_{\mathrm{H} 2^{\prime}-\mathrm{H} 1^{\prime}}=4.5 \mathrm{~Hz}, 1 \mathrm{H}, \mathrm{H}_{2^{\prime}}\right), 4.02\left(\mathrm{t}, J_{\mathrm{H}^{\prime}-\mathrm{H} 2^{\prime}}=\right.$ $\left.J_{H 3^{\prime}-H 4^{\prime}}=4.5 \mathrm{~Hz}, 1 \mathrm{H}, \mathrm{H}_{3^{\prime}}\right), 3.84\left(\mathrm{~m}, 2 \mathrm{H}, \mathrm{H}_{5^{\prime \prime}}\right), 3.72\left(\mathrm{~m}, 1 \mathrm{H}, \mathrm{H}_{5^{\prime}}\right), 3.20\left(\mathrm{dd}, J_{\mathrm{H} 6^{\prime} \mathrm{a}-\mathrm{H} 6^{\prime} \mathrm{b}^{\prime}}=13.2 \mathrm{~Hz}, J_{\mathrm{HG}^{\prime} \mathrm{a}-\mathrm{H} 5^{\prime}}=6.5\right.$ $\left.\mathrm{Hz}, 1 \mathrm{H}, \mathrm{H}_{6^{\prime} \mathrm{a}}\right), 3.00\left(\mathrm{dd}, J_{\mathrm{H}^{\prime} \mathrm{b}-\mathrm{H} 6^{\prime} \mathrm{a}}=13.2 \mathrm{~Hz}, J_{\mathrm{H}^{\prime} \mathrm{b}-\mathrm{H} 5^{\prime}}=6.5 \mathrm{~Hz}, 1 \mathrm{H}, \mathrm{H}_{6^{\prime} \mathrm{b}}\right), 1.76-1.64\left(\mathrm{~m}, 2 \mathrm{H}, \mathrm{H}_{7^{\prime \prime} \mathrm{a}}\right), 1.54-1.48$ $\left(\mathrm{m}, 2 \mathrm{H}, \mathrm{H}_{7^{\prime \prime}} \mathrm{b}\right), 0.92-0.86\left(\mathrm{~m}, 24 \mathrm{H},-\mathrm{C}\left(\mathrm{CH}_{3}\right)_{3}, \mathrm{H}_{8^{\prime \prime}}\right), 0.13,0.11,0.93,0.87\left(4 \mathrm{~s}, 12 \mathrm{H}, \mathrm{SiCH}_{3}\right) ;{ }^{13} \mathrm{C} \mathrm{NMR} \delta$ $168.3\left(C_{9^{\prime \prime}}\right), 163.2\left(C_{4}\right), 150.0\left(C_{2}\right), 140,8\left(C_{6}\right), 134.1-128.0\left(6 C_{\text {Phth }}\right), 117.8\left(C_{6^{\prime \prime}}\right), 112,6\left(C_{1^{\prime \prime}}\right), 101.5\left(C_{5}\right)$, $91.2\left(C_{1^{\prime}}\right), 86.7\left(C_{2^{\prime \prime}}\right), 85.8\left(C_{2^{\prime}}\right), 83.1\left(C_{3^{\prime \prime}}\right), 82.9\left(C_{5^{\prime}}\right), 75.6\left(C_{3^{\prime}}\right), 74.9\left(C_{4^{\prime \prime}}\right), 70.6\left(C_{4^{\prime}}\right), 44.4\left(C_{5^{\prime \prime}}\right), 43.8\left(C_{6^{\prime}}\right)$, $29.3\left(\mathrm{C}_{7^{\prime \prime} \mathrm{b}}\right), 28.9\left(\mathrm{C}_{7^{\prime \prime} \mathrm{a}}\right), 28.7\left(\mathrm{C}_{8^{\prime \prime} \mathrm{b}}\right), 27.8\left(\mathrm{C}_{8^{\prime \prime} \mathrm{a}}\right), 25.6\left(-\mathrm{C}\left(\underline{\mathrm{C}}_{3}\right)_{3}\right), 18.5,18.4\left(-\mathrm{C}\left(\mathrm{C}_{3}\right)_{3}\right),-3.9,-4.4,-4.6,-4.5$ ( $\mathrm{SiCH}_{3}$ ).; HRMS (TOF MS ESI ${ }^{+}$) Calcd for $\mathrm{C}_{40} \mathrm{H}_{62} \mathrm{~N}_{4} \mathrm{O}_{11} \mathrm{Si}_{2}{ }^{+}(\mathrm{M}+\mathrm{H})^{+} 831.3934$, found 831.40.

Side product 3: IR (film): 2930, 2300, 1700, 1463, 1437, 1395, 1260, 1168, 1120, 835, 779, 722; ${ }^{1} \mathrm{H}$ NMR $\delta 8.47\left(\mathrm{~s}, 1 \mathrm{H}, \mathrm{NH}_{\text {uracil }}\right), 7.85\left(\mathrm{~m}, 2 \mathrm{H}, \mathrm{H}_{11^{\prime \prime}}\right), 7,78\left(\mathrm{~d}, \mathrm{~J}_{\mathrm{H} 6-\mathrm{H} 5}=8.2 \mathrm{~Hz}, 1 \mathrm{H}, \mathrm{H}_{6}\right), 7.45-7.43\left(\mathrm{~m}, 2 \mathrm{H}, \mathrm{H}_{12^{\prime \prime}}\right), 6.05$ $\left(\mathrm{d}, J_{\mathrm{H} 5-\mathrm{H} 6}=8.2 \mathrm{~Hz}, 1 \mathrm{H}, \mathrm{H}_{5}\right), 5.87\left(\mathrm{~d}, J_{\mathrm{H} 1^{\prime}-\mathrm{H} 2^{\prime}}=5.5 \mathrm{~Hz}, 1 \mathrm{H}, \mathrm{H}_{1^{\prime}}\right), 5.30\left(\mathrm{~s}, 1 \mathrm{H}, \mathrm{H}_{1^{\prime \prime}}\right), 4.74\left(\mathrm{~d}, J_{\mathrm{H} 3^{\prime \prime}-\mathrm{H} 2^{\prime \prime}}=5.8 \mathrm{~Hz}, 1\right.$ $\left.\mathrm{H}, \mathrm{H}_{3^{\prime \prime}}\right), 4.63\left(\mathrm{~d}, J_{\mathrm{H} 2^{\prime \prime}-\mathrm{H} 3^{\prime \prime}}=5.8 \mathrm{~Hz}, 1 \mathrm{H}, \mathrm{H}_{2^{\prime \prime}}\right), 4.50\left(\mathrm{dd}, J_{\mathrm{H} 5^{\prime}-\mathrm{H} 6^{\prime}}=8.8 \mathrm{~Hz}, J_{\mathrm{H}^{\prime}-\mathrm{H} 4^{\prime}}=6.5 \mathrm{~Hz}, 1 \mathrm{H}, \mathrm{H}_{5^{\prime}}\right), 4.24\left(\mathrm{t}, \mathrm{J}_{\mathrm{H}^{\prime}-}\right.$

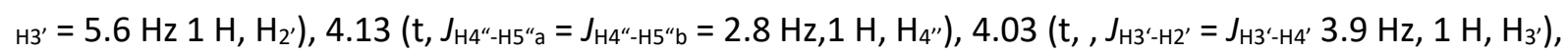
$3.9\left(\mathrm{~m}, 3 \mathrm{H}, \mathrm{H}_{4^{\prime}}, \mathrm{H}_{6^{\prime} \mathrm{a}}, \mathrm{H}_{6^{\prime} \mathrm{b}}\right), 3.5\left(\mathrm{~m}, 2 \mathrm{H}, \mathrm{H}_{5^{\prime \prime}}\right), 3.70\left(\mathrm{~m}, 1 \mathrm{H}, \mathrm{H}_{6^{\prime} \mathrm{b}}\right), 3.29\left(\mathrm{~d}, J_{\mathrm{H} 6^{\prime} \mathrm{a}-\mathrm{H} 5^{\prime}}=12.8 \mathrm{~Hz}, 1 \mathrm{H}, \mathrm{H}_{6^{\prime} \mathrm{a}}\right), 3.21$ (d, $\left.J_{\mathrm{HG}^{\prime} \mathrm{b}-\mathrm{H} 5^{\prime}}=14.8 \mathrm{~Hz}, 1 \mathrm{H}, \mathrm{H}_{5^{\prime \prime} \mathrm{a}}\right)$ 1.76-1.64 (m, $\left.2 \mathrm{H}, \mathrm{H}_{7^{\prime \prime} \mathrm{a}}\right), 1.36-1.18\left(\mathrm{~m}, 2 \mathrm{H}, \mathrm{H}_{7^{\prime \prime} \mathrm{b}}\right), 0.92-0.85(\mathrm{~m}, 24 \mathrm{H},-$ $\left.\mathrm{C}\left(\mathrm{CH}_{3}\right)_{3}, \mathrm{H}_{8^{\prime \prime}}\right), 0.13,0.11,0.93,0.87\left(4 \mathrm{~s}, 12 \mathrm{H}, \mathrm{SiCH}_{3}\right) ;{ }^{13} \mathrm{C} \mathrm{NMR} \delta 169.5\left(\mathrm{C}_{9^{\prime \prime}}\right), 168,9\left(\mathrm{C}_{7^{\prime}}\right), 163.3\left(\mathrm{C}_{4}\right), 150.5$ $\left(C_{2}\right), 140.9\left(C_{6}\right), 134.8\left(C_{11^{\prime \prime}}\right), 128.2\left(C_{10^{\prime \prime}}\right), 123.9\left(C_{12^{\prime \prime}}\right), 103.1\left(C_{5}\right), 88.9\left(C_{1^{\prime}}\right), 112.3\left(C_{1^{\prime \prime}}\right), 82.3\left(C_{3^{\prime \prime}}\right), 86.3$ $\left(C_{2^{\prime \prime}}\right), 84.7\left(C_{5^{\prime}}\right), 75.3\left(C_{2^{\prime}}\right), 85.7\left(C_{4^{\prime}}\right), 72.7\left(C_{3^{\prime}}\right), 81.3\left(C_{4^{\prime}}\right), 40.7\left(C_{6^{\prime}}\right), 42.4\left(C_{5^{\prime \prime}}\right), 118.1\left(C_{6^{\prime \prime}}\right), 8.7\left(C_{8^{\prime \prime}}\right), 7.8$ $\left(\mathrm{C}_{8^{\prime \prime} \mathrm{b}}\right), 26.1\left(\mathrm{C}_{7^{\prime \prime} \mathrm{a}}\right), 28.2\left(\mathrm{C}_{7^{\prime \prime} \mathrm{b}}\right), 26.0\left(-\mathrm{C}\left(\underline{\mathrm{C}} \mathrm{H}_{3}\right)_{3}\right), 18.3,18.2\left(-\underline{\mathrm{C}}\left(\mathrm{CH}_{3}\right)_{3}\right), 8.4,7.6\left(\mathrm{C}_{8^{\prime \prime}}\right),-3.9,-4.2,-4.6,-4.6$ $\left(\mathrm{SiCH}_{3}\right)$; HRMS (TOF MS ESI ${ }^{+}$) Calcd for $\mathrm{C}_{50} \mathrm{H}_{62} \mathrm{~N}_{4} \mathrm{O}_{11} \mathrm{Si}_{2}{ }^{+}(\mathrm{M}+\mathrm{H})^{+} 831.3954$, found 831.49.

Side product 4: IR (film): 2930, 2857, 1773, 1700, 1463, 1394, 1258, 1166, 1091, 996, 926, 866, 837, 778,$722 ;{ }^{1} \mathrm{H}$ NMR $\delta 8.71\left(\mathrm{~s}, 1 \mathrm{H}, \mathrm{NH}_{\text {uracil }}\right), 7,89$ (d, $\left.J_{\mathrm{HG}-\mathrm{H} 5}=8.2 \mathrm{~Hz}, 1 \mathrm{H}, \mathrm{H}_{6}\right), 7.60$ (d, $J_{\mathrm{H} 11^{\prime \prime}-\mathrm{H} 12^{\prime \prime}}=6.6 \mathrm{~Hz}, 1$ $\left.\mathrm{H}, \mathrm{H}_{11^{\prime \prime}}\right), 7.51\left(\mathrm{~d}, J_{\mathrm{Hg}^{\prime}-\mathrm{H} 10^{\prime}}=7.1 \mathrm{~Hz}, 1 \mathrm{H}, \mathrm{H}_{9^{\prime}}\right), 7.45-7.43\left(\mathrm{~m}, 2 \mathrm{H}, \mathrm{H}_{12^{\prime \prime}}, \mathrm{H}_{10^{\prime}}\right), 6.89\left(\mathrm{~d}, \mathrm{~J}_{\mathrm{NH}-\mathrm{NH}}=6.5 \mathrm{~Hz}, 1 \mathrm{H}\right.$, $\mathrm{NH}), 6.76\left(\mathrm{~d}, J_{\mathrm{NH}-\mathrm{NH}}=6.5 \mathrm{~Hz} \mathrm{NH}\right), 5.77\left(\mathrm{~d}, J_{\mathrm{H6}-\mathrm{H} 5}=8.2 \mathrm{~Hz}, 1 \mathrm{H}, \mathrm{H}_{5}\right), 5.51\left(\mathrm{~d}, J_{\mathrm{H} 1^{\prime}-\mathrm{H} 2^{\prime}}=1.7 \mathrm{~Hz}, 1 \mathrm{H}, \mathrm{H}_{1^{\prime}}\right), 5.24$

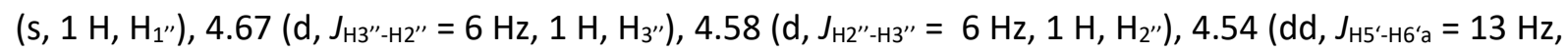
$\left.J_{\mathrm{H}^{\prime}-\mathrm{H} 4^{\prime}}=3.5 \mathrm{~Hz}, 1 \mathrm{H}, \mathrm{H}_{5^{\prime}}\right), 4.49,\left(\mathrm{~m}, 1 \mathrm{H}, \mathrm{H}_{5^{\prime \prime} \mathrm{b}}\right), 4.14\left(\mathrm{~m}, 1 \mathrm{H}, \mathrm{H}_{4^{\prime \prime}}\right), 4.10\left(\mathrm{~m}, 1 \mathrm{H}, \mathrm{H}_{2^{\prime}}\right), 4.02\left(\mathrm{~m}, 1 \mathrm{H}, \mathrm{H}_{4^{\prime}}\right), 3.97$ $\left(\mathrm{m}, 1 \mathrm{H}, \mathrm{H}_{3^{\prime}}\right), 3.70\left(\mathrm{~m}, 1 \mathrm{H}, \mathrm{H}_{6^{\prime} \mathrm{b}}\right), 3.29\left(\mathrm{~d}, J_{\mathrm{H}^{\prime} \mathrm{a}-\mathrm{H} 5^{\prime}}=12.8 \mathrm{~Hz}, 1 \mathrm{H}, \mathrm{H}_{6^{\prime} \mathrm{a}}\right), 3.21\left(\mathrm{~d}, J_{\mathrm{H} 6^{\prime} \mathrm{b}-\mathrm{H} 5^{\prime}}=14.8 \mathrm{~Hz}, 1 \mathrm{H}, \mathrm{H}_{5^{\prime \prime} \mathrm{a}}\right)$ 1.76-1.64 (m, $\left.2 \mathrm{H}, \mathrm{H}_{7^{\prime \prime}} \mathrm{a}\right), 1.36-1.18\left(\mathrm{~m}, 2 \mathrm{H}, \mathrm{H}_{7^{\prime \prime} \mathrm{b}}\right), 0.92-0.85\left(\mathrm{~m}, 24 \mathrm{H},-\mathrm{C}\left(\mathrm{CH}_{3}\right)_{3}, \mathrm{H}_{8^{\prime \prime}}\right), 0.13,0.11,0.93$, $0.87\left(4 \mathrm{~s}, 12 \mathrm{H}, \mathrm{SiCH}_{3}\right) ;{ }^{13} \mathrm{C}$ NMR $\delta 168.2\left(\mathrm{C}_{9^{\prime \prime}}\right), 163.3\left(\mathrm{C}_{4}\right), 158.1\left(\mathrm{C}_{7^{\prime}}\right), 150.5\left(\mathrm{C}_{2}\right), 140.2\left(\mathrm{C}_{6}\right), 134.7\left(\mathrm{C}_{12^{\prime \prime}}\right)$, $131.8\left(C_{10^{\prime}}\right), 124.2\left(C_{11^{\prime \prime}}=C_{9^{\prime}}\right), 102.9\left(C_{5}\right), 89.2\left(C_{1^{\prime}}\right), 112.4\left(C_{1^{\prime \prime}}\right), 82.4\left(C_{2^{\prime \prime}}\right), 86.4\left(C_{3^{\prime \prime}}\right), 84.8\left(C_{4^{\prime}}\right), 84.6\left(C_{4^{\prime \prime}}\right)$, $83.1\left(C_{5^{\prime}}\right), 75.7\left(C_{2^{\prime}}\right), 72.2\left(C_{3^{\prime}}\right), 40.7\left(C_{5^{\prime \prime}}\right), 44.2\left(C_{6^{\prime}}\right), 8.7\left(C_{8^{\prime \prime} \mathrm{a}}\right), 7.8\left(C_{8^{\prime \prime}}\right), 26.1\left(C_{7^{\prime \prime}}\right), 28.2\left(C_{7^{\prime \prime} b}\right)$; HRMS (TOF MS ESI') Calcd for $\mathrm{C}_{40} \mathrm{H}_{6} \mathrm{~N}_{4} \mathrm{O}_{10} \mathrm{Si}_{2}{ }^{+}(\mathrm{M}+\mathrm{H})^{+}$813.3921, found 813.401.

2' $^{\prime} \mathbf{3}^{\prime}$-Di-O-(tert-butyldimethylsilyl)-5'-deoxy-5'(S),6'-epoxy-uridine (5'S)-7. To a solution of alkene $\mathbf{6}^{28}$ (6.73 g, $14.36 \mathrm{mmol}, 1$ equiv.) in $\mathrm{DCM}(260 \mathrm{~mL})$, was added phosphate buffer solution 
$\left(\mathrm{NaH}_{2} \mathrm{PO}_{4} / \mathrm{Na}_{2} \mathrm{HPO}_{4}, 0.2 \mathrm{M}, \mathrm{pH}=7.2,130 \mathrm{~mL}\right)$ and $m$-CPBA (77\% stabilized, $16.09 \mathrm{~g}, 71.8 \mathrm{mmol}, 5$ equiv.). The mixture was stirred at r.t. for $16 \mathrm{~h}$. The aqueous phase was removed and the reaction was quenched by addition of $10 \%$ aqueous solution of $\mathrm{Na}_{2} \mathrm{~S}_{2} \mathrm{O}_{3}(150 \mathrm{~mL})$. The aqueous phase was extracted with DCM $(3 \times 200 \mathrm{~mL})$ and the combined organic layers were washed with $10 \%$ aqueous solution of $\mathrm{NaHCO}_{3}(100 \mathrm{~mL})$, and water $(100 \mathrm{~mL})$, dried over $\mathrm{MgSO}_{4}$, filtered and concentrated in vacuo. The crude white foam revealed to be a $75 / 25$ mixture of epoxides $\left(5^{\prime} S\right)-7 /\left(5^{\prime} R\right)-7$ as determined by ${ }^{1} \mathrm{H}$ NMR of the crude and was purified by flash chromatography (Cyclohexane/EtOAc $=8 / 2$ to $7 / 3$ ) to afford the major diastereoisomer (5'S)-7 as a white foam (4.90 g, 70\% yield). (5'S)-7: $R_{f} 0.31$ (Cyclohexane/EtOAc

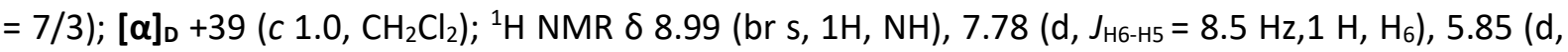
$\left.J_{\mathrm{H}^{\prime}-\mathrm{H} 2^{\prime}}=3.0 \mathrm{~Hz}, 1 \mathrm{H}, \mathrm{H}_{1^{\prime}}\right), 5.76\left(\mathrm{dd}, J_{\mathrm{H} 5-\mathrm{H} 6}=8.5 \mathrm{~Hz}, J_{\mathrm{H} 5-\mathrm{NH}}=1.5 \mathrm{~Hz}, 1 \mathrm{H}, \mathrm{H}_{5}\right), 4.28\left(\mathrm{dd}, J_{\mathrm{Hz}^{\prime}-\mathrm{H} 1^{\prime}}=3.0 \mathrm{~Hz}, J_{\mathrm{Hz} 2^{\prime}-\mathrm{H}^{\prime}}\right.$ $\left.=1.0 \mathrm{~Hz}, 1 \mathrm{H}, \mathrm{H}_{2^{\prime}}\right), 4.11-4.08\left(\mathrm{~m}, 2 \mathrm{H}, \mathrm{H}_{3^{\prime}}, \mathrm{H}_{4^{\prime}}\right), 3.20-3.19\left(\mathrm{~m}, 1 \mathrm{H}, \mathrm{H}_{5^{\prime}}\right), 2.93\left(\mathrm{dd}, J_{\mathrm{HG}^{\prime} \mathrm{a}-\mathrm{H} 6^{\prime} \mathrm{b}}=5.0 \mathrm{~Hz}, J_{\mathrm{HG}^{\prime} \mathrm{a}-\mathrm{H} 5^{\prime}}\right.$ $\left.=2.5 \mathrm{~Hz}, 1 \mathrm{H}, \mathrm{H}_{6^{\prime} \mathrm{a}}\right), 2.88\left(\mathrm{t}, J_{\mathrm{H}^{\prime} \mathrm{b}-\mathrm{H} 6^{\prime} \mathrm{a}}=5.0 \mathrm{~Hz}, J_{H 6^{\prime} \mathrm{b}-\mathrm{H} 5^{\prime}}=5.0 \mathrm{~Hz}, 1 \mathrm{H}, \mathrm{H}_{6^{\prime} \mathrm{b}}\right), 0.94,0.90\left(2 \mathrm{~s}, 18 \mathrm{H},-\mathrm{C}\left(\mathrm{C}_{3}\right)_{3}\right)$, 0.14, 0.13, 0.10, 0.09, (4s, $\left.12 \mathrm{H}, \mathrm{SiCH}_{3}\right) ;{ }^{13} \mathrm{C}$ NMR $\delta 163.4\left(\mathrm{C}_{4}\right), 150.5\left(\mathrm{C}_{2}\right), 139.9\left(\mathrm{C}_{6}\right), 102.7\left(\mathrm{C}_{5}\right), 88.9$ $\left(\mathrm{C}_{1^{\prime}}\right), 79.6\left(\mathrm{C}_{4^{\prime}}\right), 75.6\left(\mathrm{C}_{2^{\prime}}\right), 73.5\left(\mathrm{C}_{3^{\prime}}\right), 51.5\left(\mathrm{C}_{5^{\prime}}\right), 44.3\left(\mathrm{C}_{6^{\prime}}\right), 25.9,25.9\left(-\mathrm{C}\left(\underline{\mathrm{C}} \mathrm{H}_{3}\right)_{3}\right), 18.2,18.1\left(-\underline{\mathrm{C}}\left(\mathrm{CH}_{3}\right)_{3}\right),-4.2$, $-4.5,-4.6,-4.7\left(\mathrm{SiCH}_{3}\right)$. Other spectral data were in agreement with literature ${ }^{41}$.

5'(S)-C-(Phthalimidomethyl)-2',3'-di-O-(tert-butyldimethylsilyl)uridine 8. To a solution of epoxide (5'S)-7 (200 mg, $412 \mu \mathrm{mol}, 1$ equiv.) in DMF (10 mL) was added potassium phthalimide (73 mg, 495 $\mu \mathrm{mol}, 1.2$ equiv.), the resulting suspension was stirred at r.t. for $16 \mathrm{~h}$. The mixture was then diluted in EtOAc $(10 \mathrm{~mL})$, washed with brine $(4 \times 10 \mathrm{~mL})$, dried over $\mathrm{Na}_{2} \mathrm{SO}_{4}$, filtered and concentrated in vacuo. Flash chromatography of the residue (Cyclohexane/EtOAc $=7 / 3$ ) afforded the phthalimidoalcohol 8 as a white foam (168 mg, 64\% yield): $\mathrm{R}_{f} 0.13$ (Cyclohexane/EtOAc $=7 / 3$ ); $[\alpha]_{\mathrm{D}}-5$ (c 1.0, $\mathrm{CH}_{2} \mathrm{Cl}_{2}$ ); IR (film): 3628, 2859, 2356, 1695, 1263; ${ }^{1} \mathrm{H}$ NMR : 8.57 (bs, $1 \mathrm{H}, \mathrm{NH}$ ), 7.86 (dd, $\left.\mathrm{J}_{\mathrm{Hg}^{\prime}-\mathrm{H} 10^{\prime}}=3.3 \mathrm{~Hz}, 2 \mathrm{H}, \mathrm{H}_{9^{\prime}}\right), 7.73$ (dd, $\left.J_{\mathrm{H} 10^{\prime}-\mathrm{H} 9^{\prime}}=3.2 \mathrm{~Hz}, 2 \mathrm{H}, \mathrm{H}_{10^{\prime}}\right), 7.67\left(\mathrm{~d}, J_{\mathrm{H} 6-\mathrm{H} 5}=8.2 \mathrm{~Hz}, 1 \mathrm{H}, \mathrm{H}_{6}\right), 5.74\left(\mathrm{dd}, J_{\mathrm{H} 5-\mathrm{H} 6}=8.2 \mathrm{~Hz}, J_{\mathrm{H} 5-\mathrm{NH}}=1.7 \mathrm{~Hz}, 1 \mathrm{H}\right.$, $\left.\mathrm{H}_{5}\right), 5.52\left(\mathrm{~d}, J_{\mathrm{H}^{\prime}-\mathrm{H} 2^{\prime}}=5.5 \mathrm{~Hz}, 1 \mathrm{H}, \mathrm{H}_{1^{\prime}}\right), 4.52\left(\mathrm{t}, J_{\mathrm{H}^{\prime}-\mathrm{H} 2^{\prime}}=6.0 \mathrm{~Hz}, 1 \mathrm{H}, \mathrm{H}_{2^{\prime}}\right), 4.15\left(\mathrm{dd}, J_{\mathrm{H}^{\prime}-\mathrm{H}^{\prime}}=J_{\mathrm{H}^{\prime}-\mathrm{H} 4^{\prime}}=3.8 \mathrm{~Hz}\right.$, $\left.1 \mathrm{H}, \mathrm{H}_{3^{\prime}}\right), 4.06\left(\mathrm{~d}, J_{\mathrm{H}^{\prime}-\mathrm{H} 3^{\prime}}=3.3 \mathrm{~Hz}, 1 \mathrm{H}, \mathrm{H}_{4^{\prime}}\right), 4.02\left(\mathrm{~m}, 1 \mathrm{H}, \mathrm{H}_{5^{\prime}}\right), 3.93\left(\mathrm{~m}, 2 \mathrm{H}, \mathrm{H}_{6^{\prime}}\right), 0.92-0.86(\mathrm{~m}, 18 \mathrm{H},-$ $\left.\mathrm{C}\left(\mathrm{CH}_{3}\right)_{3}\right), 0.13,0.11,0.93,0.87\left(4 \mathrm{~s}, 12 \mathrm{H}, \mathrm{SiCH}_{3}\right) ;{ }^{13} \mathrm{C}$ NMR $\delta 169.0\left(\mathrm{C}_{8^{\prime}}\right), 162.9\left(\mathrm{C}_{3}\right), 150.4\left(\mathrm{C}_{1}\right), 142.9\left(\mathrm{C}_{6}\right)$, $134.5\left(C_{10^{\prime}}\right), 132.1\left(C_{8^{\prime}}\right), 123.7\left(C_{9^{\prime}}\right), 102.4\left(C_{5}\right), 93.4\left(C_{1^{\prime}}\right), 86.5\left(C_{4^{\prime}}\right), 73.4\left(C_{2^{\prime}}\right), 73.0\left(C_{3^{\prime}}\right), 69.4\left(C_{5^{\prime}}\right), 42.4$ $\left(\mathrm{C}_{6^{\prime}}\right), 25.9\left(-\mathrm{C}\left(\mathrm{CH}_{3}\right)_{3}\right), 17.9\left(-\underline{\mathrm{C}}\left(\mathrm{CH}_{3}\right)_{3}\right),-4.6\left(\mathrm{SiCH}_{3}\right)$; HRMS (TOF MS ESI ${ }^{+}$) calcd for $\mathrm{C}_{30} \mathrm{H}_{45} \mathrm{~N}_{3} \mathrm{O}_{2} \mathrm{Si}_{2}{ }^{+}(\mathrm{M}+\mathrm{H})^{+}$ 632.2848 , found 632.2849 .

\section{1",5"-Dideoxy-2",3"'-O-isopentylidene-5"'-azido-1"'-[2',3'-di-O-(tert-butyldimethylsilyl)-5'(S)-} phthalimidomethyl-uridinyl]- $\beta$-D-ribofuranose 10 . 5-Azidoribosyl fluoride $9^{42}(116 \mathrm{mg}, 474 \mu \mathrm{mol}, 3$ equiv) and phthalimidoalcohol 8 (100 mg, $158 \mu \mathrm{mol}, 1$ equiv) were dried together by co-evaporation with toluene $(3 \times 10 \mathrm{~mL})$ and dissolved in dry DCM $(8 \mathrm{~mL})$. The flask was flushed with argon and molecular sieves $4 \AA$ a was added $(1 \mathrm{~g})$ in one portion. The suspension was stirred at r.t. for $1 \mathrm{~h}$ and then cooled to $-78{ }^{\circ} \mathrm{C}$. Boron trifluoride diethyletherate $\left(89 \mu \mathrm{L}, 719 \mu \mathrm{mol}, 3.3\right.$ equiv) was added at $-78{ }^{\circ} \mathrm{C}$ and the reaction medium was stirred at this temperature for $10 \mathrm{~min}$ and was then allowed to warm to r.t. for $3 \mathrm{~h}$. The reaction mixture was filtered on a celite pad and the cake was washed with EtOAc (25 $\mathrm{mL}$ ). The reaction was quenched by the addition of a saturated aqueous $\mathrm{NaHCO}_{3}$ solution $(25 \mathrm{~mL})$ and the aqueous phase was extracted with EtOAc $(5 \times 30 \mathrm{~mL})$. The combined organic layers were dried $\left(\mathrm{Na}_{2} \mathrm{SO}_{4}\right)$, filtered and concentrated in vacuo. The resulting white foam was purified by flash chromatography (Cyclohexane/EtOAc 8/2) to give the azidoribosyl phthalimidouridine $\mathbf{1 0}$ as a $\beta / \alpha$ mixture $(\beta / \alpha=9 / 1)$ and as a white foam. The $\beta$-anomer was isolated in $64 \%$ yield: $R_{f} 0.32$ (Cyclo/EtOAc 6/4); $[\alpha]_{\mathrm{D}}-9$ (c 1, $\mathrm{CH}_{2} \mathrm{Cl}_{2}$ ); IR (film): 2928, 2856, 1715, 1698, 1394; ${ }^{1} \mathrm{H}$ NMR $\delta 8.56$ (bs, $1 \mathrm{H}, \mathrm{NH}$ ), 7.91 $\left(\mathrm{d}, J_{\mathrm{H} 6-\mathrm{H} 5}=8.0 \mathrm{~Hz}, 1 \mathrm{H}, \mathrm{H}_{6}\right), 7.86\left(\mathrm{~m}, 2 \mathrm{H}, \mathrm{H}_{11^{\prime}}\right), 7.74\left(\mathrm{~m}, 2 \mathrm{H}, \mathrm{H}_{12^{\prime}}\right), 5.88\left(\mathrm{~d}, J_{\mathrm{H} 1^{\prime}-\mathrm{H} 2^{\prime}}=4.5 \mathrm{~Hz}, 1 \mathrm{H}, \mathrm{H}_{1^{\prime}}\right), 5.79$ $\left(\mathrm{d}, J_{\mathrm{H} 5-\mathrm{H} 6}=8.0 \mathrm{~Hz}, 1 \mathrm{H}, \mathrm{H}_{5}\right), 5.08\left(\mathrm{~s}, 1 \mathrm{H}, \mathrm{H}_{1^{\prime \prime}}\right), 4.54\left(\mathrm{~d}, J_{\mathrm{H}^{\prime \prime}-\mathrm{H} 2^{\prime \prime}}=4.4 \mathrm{~Hz}, 1 \mathrm{H}, \mathrm{H}_{3^{\prime \prime}}\right), 4.46\left(\mathrm{~d}, J_{\mathrm{H}^{\prime \prime}-\mathrm{H} 3^{\prime \prime}}=4.4 \mathrm{~Hz}\right.$, $\left.1 \mathrm{H}, \mathrm{H}_{2^{\prime \prime}}\right), 4.25\left(\mathrm{~m}, 1 \mathrm{H}, \mathrm{H}_{5^{\prime}}\right), 4.21\left(\mathrm{~m}, 1 \mathrm{H}, \mathrm{H}_{5^{\prime \prime} \mathrm{a}}\right), 4.158\left(\mathrm{t}, J_{\mathrm{H} 2^{\prime}-\mathrm{H} 1^{\prime}}=J_{\mathrm{H}^{\prime}-\mathrm{H} 3^{\prime}}=4.5 \mathrm{~Hz}, 1 \mathrm{H}, \mathrm{H}_{2^{\prime}}\right), 4.06\left(\mathrm{dd}, J_{\mathrm{H} 4^{\prime}-}\right.$ $\mathrm{H}^{\prime}=10 \mathrm{~Hz}, J_{\mathrm{H} 4^{\prime}-\mathrm{H} 3^{\prime}}=4.5 \mathrm{~Hz}, 1 \mathrm{H}, \mathrm{H}_{4^{\prime}}$ and $\left.\mathrm{H}_{4^{\prime \prime}}\right), 4.01\left(\mathrm{t}, J_{\mathrm{H} 3^{\prime}-\mathrm{H} 2^{\prime}}=J_{\mathrm{H} 3^{\prime}-\mathrm{H} 4^{\prime}}=4.35 \mathrm{~Hz}, 1 \mathrm{H}, \mathrm{H}_{3^{\prime}}\right), 3.82\left(\mathrm{dd}, J_{\mathrm{H} 5^{\prime \prime} \mathrm{b}-}\right.$ 
$\left.H 5^{\prime \prime a}=13 \mathrm{~Hz}, J_{H 5^{\prime \prime b}-H 4^{\prime \prime}}=4.4 \mathrm{~Hz}, 1 \mathrm{H}, \mathrm{H}_{5^{\prime \prime} \mathrm{b}}\right), 3.24$ (dd, $\left.J_{H 6^{\prime} \mathrm{b}-H 6^{\prime} \mathrm{a}}=12.8 \mathrm{~Hz}, J_{H 6^{\prime} b-H 5^{\prime}}=4.9 \mathrm{~Hz}, 1 \mathrm{H}, \mathrm{H}_{6^{\prime} \mathrm{b}}\right), 3.14$ (dd, $\left.J_{H 6^{\prime} b-H 6^{\prime} \mathrm{a}}=12.8 \mathrm{~Hz}, J_{H 6^{\prime} b-H 5^{\prime}}=5.8 \mathrm{~Hz}, 1 \mathrm{H}, \mathrm{H}_{6^{\prime} \mathrm{b}}\right), 1.66$ (q, $\left.J_{H 7^{\prime \prime} \mathrm{a}-H 8^{\prime \prime}}=7.7 \mathrm{~Hz}, 2 \mathrm{H}, \mathrm{H}_{7^{\prime \prime} \mathrm{a}}\right), 1.53$ (q, $J_{\mathrm{H} 7^{\prime \prime} \mathrm{b}-H 8^{\prime \prime}}=7.7$ $\left.\mathrm{Hz}, 2 \mathrm{H}, \mathrm{H}_{7^{\prime \prime}} \mathrm{b}\right), 0.76-0.35\left(\mathrm{~m}, 24 \mathrm{H},-\mathrm{C}\left(\mathrm{CH}_{3}\right), \mathrm{H}_{8^{\prime \prime}}\right), 0.05,0.05,0.07,0.08\left(4 \mathrm{~s}, \mathrm{SiCH}_{3}\right) ;{ }^{13} \mathrm{C} \mathrm{NMR} \delta 168.2\left(\mathrm{C}_{9^{\prime}}\right)$, $162.9\left(C_{4}\right), 150.2\left(C_{2}\right), 140.2\left(C_{6}\right), 134.0\left(C_{12^{\prime}}\right), 132.3\left(C_{10^{\prime}}\right), 123.2\left(C_{11^{\prime}}\right), 118.4\left(C_{6^{\prime \prime}}\right), 112.2\left(C_{1^{\prime \prime}}\right), 102.1\left(C_{5}\right)$, 88.6 $\left(C_{1^{\prime}}\right), 85.4\left(C_{2^{\prime \prime}}\right), 84.4\left(C_{4^{\prime}}=C_{4^{\prime \prime}}\right), 81.4\left(C_{3^{\prime \prime}}\right), 77.4\left(C_{5^{\prime}}\right), 75.4\left(C_{2^{\prime}}\right), 72.1\left(C_{3^{\prime}}\right), 52.8\left(C_{5^{\prime \prime}}\right), 39.8\left(C_{6^{\prime}}\right), 29.3$ $\left(\mathrm{C}_{7^{\prime \prime} \mathrm{b}}\right), 28.9\left(\mathrm{C}_{7^{\prime \prime} \mathrm{a}}\right), 28.4\left(\mathrm{C}_{8^{\prime \prime} \mathrm{b}}\right), 27.6\left(\mathrm{C}_{8^{\prime \prime} \mathrm{a}}\right), 25.7\left(-\mathrm{C}\left(\underline{C}_{3}\right)_{3}\right), 18.2,18.2\left(-\mathrm{C}\left(\mathrm{C}_{3}\right)_{3}\right),-3.9,-4.2,-4.7,-4.7$ $\left(\mathrm{SiCH}_{3}\right)$; HRMS (TOF MS ESI ${ }^{+}$) calcd for $\mathrm{C}_{40} \mathrm{H}_{61} \mathrm{~N}_{6} \mathrm{O}_{11} \mathrm{Si}_{2}{ }^{+}(\mathrm{M}+\mathrm{H})^{+} 857.3931$, found 857.3936.

\section{1",5"'-Dideoxy-2", 3"'-0-isopentylidene-5"'-azido-1"'-[2',3'-0-isopropylidene-5'(S)-aminomethyl-}

uridinyl]- $\beta$-D-ribofuranose 11. To the glycosylated compound 10 (270 mg, $315 \mu \mathrm{mol}, 1$ equiv.) dissolved in $10 \mathrm{~mL}$ of $\mathrm{MeOH}$ was added dropwise hydrazine monohydrate $(154 \mu \mathrm{L}, 3,15 \mathrm{mmol}, 10$ equiv.). The reaction mixture was stirred for $12 \mathrm{~h}$ at r.t. and concentrated in vacuo. The product was then dissolved in DCM, filtered through a celite pad, and rinsed with DCM. The amine $\mathbf{1 1}$ was obtained in quantitative yield: $[\alpha]_{D}-39$ (c 1, $\left.\mathrm{CH}_{2} \mathrm{Cl}_{2}\right)$; IR (film): 2925, 2854, 2098, 1688, 1578, 1671, 1384, 1275, $1260,1211,1177,1134,855,800,764,750,722 ;{ }^{1} \mathrm{H}$ NMR $\delta 7.87$ (d, $\left.J_{H G-H 5}=8.2 \mathrm{~Hz}, 1 \mathrm{H}, \mathrm{H}_{6}\right), 5.76$ (d, $J_{H 1^{\prime}-}$ $\left.\mathrm{H}^{\prime}=3.2 \mathrm{~Hz}, 1 \mathrm{H}, \mathrm{H}_{1^{\prime}}\right), 5.69\left(\mathrm{~d}, J_{\mathrm{H} 5-\mathrm{H} 6}=8.2 \mathrm{~Hz}, 1 \mathrm{H}, \mathrm{H}_{5}\right), 5.20\left(\mathrm{~s}, 1 \mathrm{H}, \mathrm{H}_{1^{\prime \prime}}\right), 4.62\left(\mathrm{dd}, J_{\mathrm{H}^{\prime \prime}-\mathrm{H} 2^{\prime \prime}}=6.3, J_{\mathrm{H}^{\prime \prime}-\mathrm{H} 4^{\prime \prime}}=\right.$ $\left.1.6 \mathrm{~Hz}, 1 \mathrm{H}, \mathrm{H}_{3^{\prime \prime}}\right), 4.52\left(\mathrm{~d}, J_{\mathrm{H} 2^{\prime \prime}-\mathrm{H} 3^{\prime \prime}}=6.3 \mathrm{~Hz}, 1 \mathrm{H}, \mathrm{H}_{2^{\prime \prime}}\right), 4.34\left(\mathrm{td}, J_{\mathrm{H}^{\prime \prime}-\mathrm{H} 5^{\prime \prime}}=5.6, J_{\mathrm{H}^{\prime \prime}-\mathrm{H} 3^{\prime \prime}}=1.5 \mathrm{~Hz}, 1 \mathrm{H}, \mathrm{H}_{4^{\prime \prime}}\right), 4.18$ $\left(\mathrm{dd}, J_{\mathrm{H} 2^{\prime}-\mathrm{H} 3^{\prime}}=5.4, J_{\mathrm{H}^{\prime}-\mathrm{H} 1^{\prime}}=3.2 \mathrm{~Hz}, 1 \mathrm{H}, \mathrm{H}_{2^{\prime}}\right), 4.16\left(\mathrm{t}, J_{\mathrm{H} 4^{\prime}-\mathrm{H} 3^{\prime}}=4.2 \mathrm{~Hz}, 1 \mathrm{H}, \mathrm{H}_{4^{\prime}}\right), 3.99$ (dd, $J_{\mathrm{H}^{\prime}-\mathrm{H} 2^{\prime}}=5.4, J_{\mathrm{H} 3^{\prime}-\mathrm{H} 4^{\prime}}$ $\left.=4.2 \mathrm{~Hz}, 1 \mathrm{H}, \mathrm{H}_{3^{\prime}}\right), 3.67\left(\mathrm{t}, J_{\mathrm{H} 5^{\prime}-\mathrm{H} 6^{\prime} \mathrm{a}}=J_{\mathrm{H}^{\prime}-\mathrm{H} 6^{\prime} \mathrm{b}}=5.6 \mathrm{~Hz}, 1 \mathrm{H}, \mathrm{H}_{5^{\prime}}\right), 3.51\left(\mathrm{dd}, J_{\mathrm{H} 5^{\prime \prime} \mathrm{a}-\mathrm{H} 5^{\prime \prime} \mathrm{b}}=12.8, J_{\mathrm{H}^{\prime \prime}-\mathrm{H} 4^{\prime \prime}}=5.6 \mathrm{~Hz}\right.$,

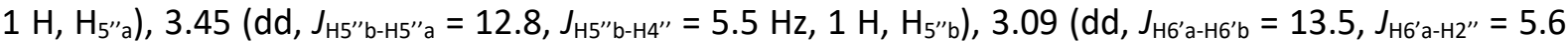

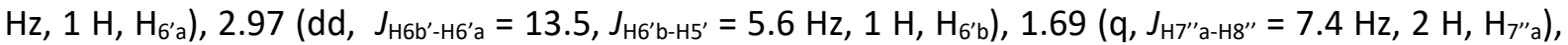
$1.55\left(\mathrm{q}, \mathrm{J}_{\mathrm{H} 7^{\prime \prime} \mathrm{b}-\mathrm{H} 8^{\prime \prime}}=7.4 \mathrm{~Hz}, 1 \mathrm{H}, \mathrm{H}_{7^{\prime \prime} \mathrm{b}}\right), 0.93-0.83\left(24 \mathrm{H},-\mathrm{C}\left(\mathrm{CH}_{3}\right)_{3}, \mathrm{H}_{8^{\prime \prime}}\right), 0.08\left(\mathrm{~s}, 12 \mathrm{H}, \mathrm{SiCH}_{3}\right) . ;{ }^{13} \mathrm{C} \mathrm{NMR} \delta$ 169.3 $\left(C_{3}\right), 150.3\left(C_{4}\right), 141.3\left(C_{6}\right), 117.7\left(C_{6^{\prime \prime}}\right), 111.9\left(C_{1^{\prime \prime}}\right), 102.2\left(C_{5}\right), 91.1\left(C_{1^{\prime}}\right), 87.5\left(C_{4^{\prime \prime}}\right), 86.5\left(C_{3^{\prime \prime}}\right), 84.0$ $\left(C_{4^{\prime}}\right), 82.3\left(C_{2^{\prime \prime}}\right), 77.9\left(C_{5^{\prime}}\right), 74.8\left(C_{2^{\prime}}\right), 71.8\left(C_{3^{\prime}}\right), 51.8\left(C_{6^{\prime \prime}}\right), 44.3\left(C_{5^{\prime \prime}}\right), 29.4 ; 29.0\left(C_{7^{\prime \prime}}\right) ; 27.0 ; 26.0,21.2$; 21.2; 18.6; 14.3; 8.5; 7.6 (-Si-t $\left.\underline{-\mathrm{Bu}}-\left(\mathrm{CH}_{3}\right) 2, \mathrm{CH}_{3}\left(\mathrm{H}_{8^{\prime}}\right)\right)$, -4.0; -4.3; -4.5; -4.6 $\left(\mathrm{CH}_{3}-\mathrm{Si}\right) ; \mathrm{HRMS} \mathrm{APCl}^{+}$calcd for $\mathrm{C}_{32} \mathrm{H}_{59} \mathrm{~N}_{6} \mathrm{O}_{9} \mathrm{Si}_{2}^{+}(\mathrm{M}+\mathrm{H})^{+}$727.3877, found 727.38770 .

\section{General procedure for the synthesis of ureas 23a-23k}

To a solution of the indicated amines (1.2 equiv.) in dry DCM $(1 \mathrm{~mL})$ were added triethylamine (3.0 or 4.0 equiv.) and carbonyldiimidazole (1.2 equiv.). The resulting mixture was stirred at $0{ }^{\circ} \mathrm{C}$ for $10 \mathrm{~min}$ and then at r.t. for $3 \mathrm{~h}$. The amine 11 (1 equiv.) dissolved in dry DCM $(1 \mathrm{~mL})$ was added dropwise to the reaction mixture and stirred at $30{ }^{\circ} \mathrm{C}$. After $12 \mathrm{~h}$, the mixture was concentrated in vacuo. Flash chromatography afforded the pure ureas.

Urea 23a. The reaction was carried out according to the general procedure for the synthesis of urea from decylamine (16.5 mL, $83 \mathrm{mmol}, 1.2$ equiv.), triethylamine $(28.8 \mathrm{ml}, 206 \mathrm{mmol}, 3.0$ equiv.) and carbonyldiimidazole ( $13.38 \mathrm{mg}, 83 \mathrm{mmol}, 1.2$ equiv.) with the amine 11 (50 mg, $69 \mathrm{mmol}, 1$ equiv.). Flash chromatography of the residue (Cyclohexane/EtOAc $=6 / 4)$ afforded the urea 23a as a yellow oil (46 mg, 73\% yield): $\mathrm{R}_{f} 0.50$ (Cyclohexane/EtOAc = 6/4); [ $\left.\alpha\right]_{D}-6$ (c 1.0, $\mathrm{CH}_{2} \mathrm{Cl}_{2}$ ); IR (film): 2929, 2901, $2105,1697,1463,1275,1260,1100,874,838,764,750 ;{ }^{1} \mathrm{H}$ NMR $\delta 8.38(\mathrm{~s}, 1 \mathrm{H}, \mathrm{NH}), 7.80\left(\mathrm{~d}, \mathrm{~J}_{\mathrm{H} 6-\mathrm{H} 5}=8.0\right.$ $\left.\mathrm{Hz}, 1 \mathrm{H}, \mathrm{H}_{6}\right), 5.76\left(\mathrm{~d}, J_{\mathrm{H}^{\prime}-\mathrm{H} 2^{\prime}}=3.4 \mathrm{~Hz}, 1 \mathrm{H}, \mathrm{H}_{1^{\prime}}\right), 5.70\left(\mathrm{~d}, \mathrm{~J}_{\mathrm{H} 5-\mathrm{H} 6}=8.0 \mathrm{~Hz}, 1 \mathrm{H}, \mathrm{H}_{5}\right), 5.20\left(\mathrm{~s}, 1 \mathrm{H}, \mathrm{H}_{1^{\prime \prime}}\right), 4.60(\mathrm{~d}$, $\left.J_{H 3^{\prime \prime}-\mathrm{H}^{\prime \prime}}=6.1 \mathrm{~Hz}, 1 \mathrm{H}, \mathrm{H}_{3^{\prime \prime}}\right), 4.53\left(\mathrm{~d}, J_{\mathrm{H}^{\prime \prime}-\mathrm{H} 3^{\prime \prime}}=6.1 \mathrm{~Hz}, 1 \mathrm{H}, \mathrm{H}_{2^{\prime \prime}}\right), 4.38\left(\mathrm{t}, J_{\mathrm{H}^{\prime \prime}-\mathrm{H} 5^{\prime \prime}}=5.5 \mathrm{~Hz}, 1 \mathrm{H}, \mathrm{H}_{4^{\prime \prime}}\right), 4.21(\mathrm{t}$, $\left.J_{\mathrm{H}^{\prime}-\mathrm{H} 1^{\prime}}=3.4 \mathrm{~Hz}, 1 \mathrm{H}, \mathrm{H}_{2^{\prime}}\right), 4.14-4.09\left(\mathrm{~m}, 1 \mathrm{H}, \mathrm{H}_{3^{\prime}}\right), 4.00\left(\mathrm{~d}, J_{\mathrm{H}^{\prime}-\mathrm{H} 3^{\prime}}=3.7 \mathrm{~Hz}, 1 \mathrm{H}, \mathrm{H}_{4^{\prime}}\right), 3.84\left(\mathrm{~s}, 1 \mathrm{H}, \mathrm{H}_{5^{\prime}}\right), 3.64$

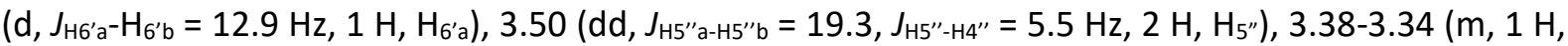

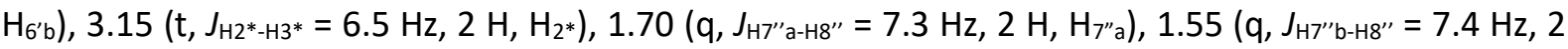
$\left.\mathrm{H}, \mathrm{H}_{7^{\prime \prime}}\right), 1.48\left(\mathrm{~m}, 2 \mathrm{H}, \mathrm{H}_{3^{*}}\right), 1.36-1.20(\mathrm{~m}, 20 \mathrm{H}), 0.96-0.78(\mathrm{~m}, 34 \mathrm{H}), 0.09\left(\mathrm{~m}, 12 \mathrm{H}, \mathrm{SiCH}_{3}\right) ;{ }^{13} \mathrm{C} \mathrm{NMR}$ $\delta 161.3\left(C_{4}\right), 158.2\left(C_{8^{\prime}}\right), 150.1\left(C_{2}\right), 140.5\left(C_{6}\right), 118.2\left(C_{6^{\prime \prime}}\right), 112.1\left(C_{1^{\prime \prime}}\right), 101.8\left(C_{5}\right), 89.7\left(C_{7}\right), 86.0\left(C_{2^{\prime \prime}}\right)$, $85.1\left(C_{3^{\prime}}\right), 85.0\left(C_{4^{\prime \prime}}\right), 81.7\left(C_{3^{\prime \prime}}\right), 80.6\left(C_{5^{\prime}}\right), 75.1\left(C_{2^{\prime}}\right), 71.8\left(C_{4^{\prime}}\right), 53.8\left(C_{5^{\prime \prime}}\right), 42.7\left(C_{6^{\prime}}\right), 40.9\left(C_{2^{*}}\right)$, 38.4, 31.9, 31.3, 30.3, $30.2\left(C_{2^{*}}\right), 29.8\left(C_{7^{\prime \prime} \mathrm{a}}\right), 29.6,29.5,29.4,29.4,29.2\left(C_{7^{\prime \prime} \mathrm{b}}\right), 29.0,28.9,27.0,26.5,25.8,22.7$, 
18.1, 14.2, 8.4, 7.6, 7.5, -4.0, -4.3, -4.6; $\mathrm{HRMS} \mathrm{APCl}^{+}$calcd for $\mathrm{C}_{43} \mathrm{H}_{79} \mathrm{~N}_{7} \mathrm{O}_{10} \mathrm{Si}_{2}{ }^{+}(\mathrm{M}+\mathrm{H})^{+} 910.5500$, found 910.5500 .

Urea 23b. The reaction was carried out according to the general procedure for the synthesis of urea from dodecylamine ( $15.3 \mathrm{mg}, 83 \mathrm{mmol}, 1.2$ equiv.), triethylamine $(28.8 \mathrm{ml}, 206 \mathrm{mmol}, 3.0$ equiv.) and carbonyldiimidazole (13.4 mg, $83 \mathrm{mmol}, 1.2$ equiv.) with the amine 11 (50 mg, $69 \mathrm{mmol}, 1$ equiv.). Flash chromatography of the residue (Cyclohexane/EtOAc $=6 / 4$ ) afforded the urea $\mathbf{2 3 b}$ as a colorless oil (42 mg, 76\% yield): $\mathrm{R}_{f} 0.5$ (Cyclohexane/EtOAc = 6/4); $[\alpha]_{\mathrm{D}}-9$ (c 1.0, $\mathrm{CH}_{2} \mathrm{Cl}_{2}$ ); IR (film) 2926, 2854, $2106,1698,1664,1275,1260,1100,840,764,750 ;{ }^{1} \mathrm{H} N M R \delta 8.46(\mathrm{~s}, 1 \mathrm{H}, \mathrm{NH}), 7.80$ (d, $J_{\mathrm{H} 6-\mathrm{H} 5}=8.2 \mathrm{~Hz}$, $\left.1 \mathrm{H}, \mathrm{H}_{6}\right), 5.76\left(\mathrm{~d}, J_{\mathrm{H}^{\prime}-\mathrm{H} 2^{\prime}}=4.2 \mathrm{~Hz}, 1 \mathrm{H}, \mathrm{H}_{1^{\prime}}\right), 5.70\left(\mathrm{~d}, J_{\mathrm{H} 5-\mathrm{H} 6}=8.1 \mathrm{~Hz}, 1 \mathrm{H}, \mathrm{H}_{5}\right), 5.20\left(\mathrm{~s}, 1 \mathrm{H}, \mathrm{H}_{1^{\prime \prime}}\right), 4.61\left(\mathrm{~d}, J_{\mathrm{H} 3^{\prime \prime}-}\right.$ $\left.\mathrm{H}^{\prime \prime}=6.2 \mathrm{~Hz}, 1 \mathrm{H}, \mathrm{H}_{3^{\prime \prime}}\right), 4.53\left(\mathrm{~d}, J_{\mathrm{H} 2^{\prime \prime}-\mathrm{H} 3^{\prime \prime}}=6.2 \mathrm{~Hz}, 1 \mathrm{H}, \mathrm{H}_{2^{\prime \prime}}\right), 4.38\left(\mathrm{t}, J_{\mathrm{H} 4^{\prime \prime}-\mathrm{H} 2^{\prime \prime}}=5.9, \mathrm{~Hz}, 1 \mathrm{H}, \mathrm{H}_{4^{\prime \prime}}{ }^{\prime \prime}\right), 4.21\left(\mathrm{t}, J_{\mathrm{H}^{\prime}-}\right.$ $\left.\mathrm{H}^{\prime}=4.2 \mathrm{~Hz}, 1 \mathrm{H}, \mathrm{H}_{2^{\prime}}\right), 4.12\left(\mathrm{dd}, J_{\mathrm{H} 3^{\prime}-\mathrm{H} 2^{\prime}}=J_{\mathrm{H} 2^{\prime}-\mathrm{H} 4^{\prime}}=4.2 \mathrm{~Hz}, 1 \mathrm{H}, \mathrm{H}_{3^{\prime}}\right), 4.00\left(\mathrm{t}, J_{\mathrm{H} 4^{\prime}-\mathrm{H} 3^{\prime}}=4.2 \mathrm{~Hz}, 1 \mathrm{H}, \mathrm{H}_{4^{\prime}}\right), 3.85-$ $3.80\left(\mathrm{~m}, 1 \mathrm{H}, \mathrm{H}_{5^{\prime}}\right), 3.64$ (dd, $J_{H 6^{\prime} \mathrm{a}-\mathrm{H} 6^{\prime} \mathrm{b}}=14.3, J_{H 6^{\prime} \mathrm{a}-\mathrm{H} 5^{\prime}}=4.2 \mathrm{~Hz}, 1 \mathrm{H}, \mathrm{H}_{6^{\prime} \mathrm{a}}$ ), 3.50 (ddd, J J $\mathrm{H}^{\prime \prime} \mathrm{a}-\mathrm{H} 5^{\prime \prime b}=19.7, J_{\mathrm{H} 5^{\prime \prime} \mathrm{a}-}$ $\mathrm{H} 4^{\prime \prime}=5.9 \mathrm{~Hz}, 2 \mathrm{H}, \mathrm{H}_{5^{\prime \prime}}$ ), $3.36\left(\mathrm{dd}, J_{\mathrm{H}^{\prime} \mathrm{b}-\mathrm{H} 6^{\prime} \mathrm{a}}=14.3, J_{\mathrm{H} 6^{\prime} \mathrm{b}-\mathrm{H} 5^{\prime}}=7.2 \mathrm{~Hz}, 1 \mathrm{H}, \mathrm{H}_{6^{\prime} \mathrm{b}}\right.$ ), $3.14\left(\mathrm{dd}, J_{\mathrm{H} 2^{\prime \prime}-\mathrm{H} 3^{\prime \prime}}=7.4, J_{\mathrm{H}^{\prime \prime}-\mathrm{NH}}\right.$ $\left.=5.6 \mathrm{~Hz}, 2 \mathrm{H}, \mathrm{H}_{2^{*}}\right), 1.70\left(\mathrm{q}, J_{\mathrm{H} 7^{\prime \prime} \mathrm{a}-\mathrm{H} 8^{\prime \prime}}=7.3 \mathrm{~Hz}, 2 \mathrm{H}, \mathrm{H}_{7^{\prime \prime} \mathrm{a}}\right), 1.55$ (q, $\left.J_{\mathrm{H} 7^{\prime \prime} \mathrm{b}-\mathrm{H} 8^{\prime \prime}}=7.3 \mathrm{~Hz}, 2 \mathrm{H}, \mathrm{H}_{7^{\prime \prime} \mathrm{b}}\right), 1.51-1.46$ $\left(\mathrm{m}, 24 \mathrm{H},,-\mathrm{C}\left(\mathrm{CH}_{3}\right)_{3}, \mathrm{H}_{8^{\prime \prime}}\right), 0.9(\mathrm{~m}, 2 \mathrm{H}), 0.1\left(\mathrm{~m}, 15 \mathrm{H}, \mathrm{SiCH}_{3}, \mathrm{H}_{13^{*}}\right) ;{ }^{13} \mathrm{C} \mathrm{NMR} \delta 162.9\left(\mathrm{C}_{4}\right), 158.2\left(\mathrm{C}_{8^{\prime}}\right), 150.1$ $\left(C_{2}\right), 140.5\left(C_{6}\right), 118.1\left(C_{6^{\prime \prime}}\right), 112.0\left(C_{1^{\prime \prime}}\right), 101.8\left(C_{5}\right), 89.8\left(C_{1^{\prime}}\right), 85.8\left(C_{2^{\prime \prime}}\right), 85.1\left(C_{3^{\prime}}\right), 85.0\left(C_{4^{\prime \prime}}\right), 81.7\left(C_{3^{\prime \prime}}\right)$, $80.6\left(C_{5^{\prime}}\right), 75.1\left(C_{2^{\prime}}\right), 71.8\left(C_{4^{\prime}}\right), 53.8\left(C_{5^{\prime \prime}}\right), 42.7\left(C_{6^{\prime}}\right), 40.8\left(C_{2^{*}}\right), 32.0,31.0,30.2\left(C_{2^{*}}\right), 29.7,29.7,29.7$, 29.7, 29.4, 29.4, 29.3 ( $\left.C_{7^{\prime \prime} \mathrm{a}}\right), 28.8$ ( $\left.\mathrm{C}_{7^{\prime \prime} \mathrm{b}}\right), 27.0,25.9,25.8,22.7,18.1,18.1,14.2,8.4,7.6,-4.0,-4.3,-4.6$, -4.6; HRMS (TOF MS ES ${ }^{+}$) calcd for $\mathrm{C}_{45} \mathrm{H}_{84} \mathrm{~N}_{7} \mathrm{O}_{9} \mathrm{Si}_{2}{ }^{+}(\mathrm{M}+\mathrm{H})^{+} 938.5813$, found 938.5848 .

Urea 23c. The reaction was carried out according to the general procedure for the synthesis of urea from compound $13 \mathrm{c}$ (19.3 mg, $83 \mathrm{mmol}, 1.2$ equiv.), triethylamine ( $28.8 \mathrm{ml}, 206 \mathrm{mmol}, 3.0$ equiv.) and carbonyldiimidazole (13.4 mg, $83 \mathrm{mmol}, 1.2$ equiv.) with the amine 11 (50 mg, $69 \mathrm{mmol}, 1$ equiv.). Flash chromatography of the residue $(C y c l o h e x a n e / E t O A c=6 / 4)$ afforded the urea $23 \mathrm{c}$ as a colorless oil (45 mg, 66\% yield): $\mathrm{R}_{f} 0.55$ (Cyclohexane/EtOAc = 6/4); [ $\left.\alpha\right]_{\mathrm{D}}-7$ (c 1.0, $\mathrm{CH}_{2} \mathrm{Cl}_{2}$ ); IR (film) 3356, 2928, $2855,2105,1694,1637,1568,1452,1376,1275,1260,1166,1099,1005,925,867,838,764,750 ;{ }^{1} \mathrm{H}$ NMR $\delta 8.4(\mathrm{~s}, 1 \mathrm{H}, \mathrm{NH}), 7.80\left(\mathrm{~d}, J_{\mathrm{HG}-\mathrm{H} 5}=8.2 \mathrm{~Hz}, 1 \mathrm{H}, \mathrm{H}_{6}\right), 7.32-7.10\left(\mathrm{~m}, 5 \mathrm{H}, \mathrm{H}_{\text {aro }}\right), 5.76\left(\mathrm{~d}, J_{\mathrm{H} 1^{\prime}-\mathrm{Hz}^{\prime}}=4.2 \mathrm{~Hz}\right.$, $\left.1 \mathrm{H}, \mathrm{H}_{1^{\prime}}\right), 5.69\left(\mathrm{~d}, \mathrm{~J}_{\mathrm{H} 5-\mathrm{H} 6}=8.2 \mathrm{~Hz}, 1 \mathrm{H}, \mathrm{H}_{5}\right), 5.20\left(\mathrm{~s}, 1 \mathrm{H}, \mathrm{H}_{1^{\prime \prime}}\right), 4.60\left(\mathrm{~d}, J_{\mathrm{H} 3^{\prime \prime}-\mathrm{H} 2^{\prime \prime}}=6.2 \mathrm{~Hz}, 1 \mathrm{H}, \mathrm{H}_{3^{\prime \prime}}\right), 4.52(\mathrm{~d}$, $\left.J_{H 2^{\prime \prime}-H 3^{\prime \prime}}=6.2 \mathrm{~Hz}, 1 \mathrm{H}, \mathrm{H}_{2^{\prime \prime}}\right), 4.37\left(\mathrm{t}, J_{\mathrm{H} 4^{\prime \prime}-H 5^{\prime \prime}}=5.2 \mathrm{~Hz}, 1 \mathrm{H}, \mathrm{H}_{4^{\prime \prime}}\right), 4.21\left(\mathrm{t}, J_{\mathrm{H} 2^{\prime}-\mathrm{H} 1^{\prime}}=4.2 \mathrm{~Hz}, 1 \mathrm{H}, \mathrm{H}_{2^{\prime}}\right), 4.12$ (dd, $\left.J_{H 4^{\prime}-H 5^{\prime}}=J_{H 4^{\prime}-H 3^{\prime}}=4.5 \mathrm{~Hz}, 1 \mathrm{H}, \mathrm{H}_{4^{\prime}}\right), 4.00\left(\mathrm{~d}, J_{\mathrm{H} 3^{\prime}-\mathrm{H} 2^{\prime}}=4.2 \mathrm{~Hz}, 1 \mathrm{H}, \mathrm{H}_{3^{\prime}}\right), 3.84\left(\mathrm{~m}, 1 \mathrm{H}, \mathrm{H}_{5^{\prime}}\right), 3.63\left(\mathrm{dd}, J_{\mathrm{H} 6^{\prime} \mathrm{a}-\mathrm{H} 6^{\prime} \mathrm{b}}=\right.$ $\left.14.0, J_{H 6^{\prime} \mathrm{a}-H 5^{\prime}}=3.2 \mathrm{~Hz}, 1 \mathrm{H}, \mathrm{H}_{6^{\prime} \mathrm{a}}\right), 3.49$ (ddd, $\left.J_{\mathrm{H} 5^{\prime \prime} \mathrm{a}-\mathrm{H} 5^{\prime \prime b}}=19.6, J_{H 5^{\prime \prime} \mathrm{a}-\mathrm{H}^{\prime \prime}}=J_{H 5^{\prime \prime} \mathrm{b}-\mathrm{H} 4^{\prime \prime}}=5.2 \mathrm{~Hz}, 2 \mathrm{H}, \mathrm{H}_{5^{\prime \prime}}\right), 3.36$ (dd, $\left.J_{H 6^{\prime} b-H 6^{\prime} \mathrm{a}}=14.0, J_{\mathrm{H}^{\prime} \mathrm{b}-\mathrm{H} 5^{\prime}}=7.1 \mathrm{~Hz}, 1 \mathrm{H}, \mathrm{H}_{6^{\prime} \mathrm{b}}\right), 3.14\left(\mathrm{td}, J_{\mathrm{H} 2^{*}-\mathrm{H} 3^{*}}=6.7, J_{\mathrm{H}^{*}-\mathrm{NH}}=1.5 \mathrm{~Hz}, 2 \mathrm{H}, \mathrm{H}_{2^{*}}\right), 2.62-2.56$ $\left(\mathrm{m}, 2 \mathrm{H}, \mathrm{H}_{11^{*}}\right), 1.70\left(\mathrm{q}, J_{\mathrm{H}^{\prime \prime} \mathrm{a}-\mathrm{H} 8^{\prime \prime}}=7.3 \mathrm{~Hz}, 2 \mathrm{H}, \mathrm{H}_{7^{\prime \prime}} \mathrm{a}\right), 1.61\left(\mathrm{dd}, J_{\mathrm{H}^{*}-\mathrm{H} 10^{*}}=J_{\mathrm{H} 9^{*}-\mathrm{H} 8^{*}}=7.6 \mathrm{~Hz}, 2 \mathrm{H}, \mathrm{H}_{9^{*}}\right), 1.55$ (q, $\left.J_{H 7^{\prime \prime b}-H 8^{\prime \prime}}=7.3 \mathrm{~Hz}, 2 \mathrm{H}, \mathrm{H}_{7^{\prime \prime} \mathrm{b}}\right), 1.50-1.46\left(\mathrm{~m}, 2 \mathrm{H}, \mathrm{H}_{2^{*}}\right), 1.27(\mathrm{~m}, 14 \mathrm{H}), 0.9(\mathrm{~m}, 30 \mathrm{H}), 0.1\left(\mathrm{~m}, 12 \mathrm{H}, \mathrm{SiCH}_{3}\right)$; ${ }^{13}{ }^{1}$ NMR $\delta 162.8\left(C_{4}\right), 158.2\left(C_{8^{\prime}}\right), 150.1\left(C_{2}\right), 143.0\left(C_{12^{*}}\right), 140.5\left(C_{6}\right), 128.5-128.3-125.7\left(C_{\text {aro }}\right), 118.2\left(C_{6^{\prime \prime}}\right)$ $112.1\left(C_{1^{\prime \prime}}\right), 101.8\left(C_{5}\right), 89.8\left(C_{1^{\prime}}\right), 86.0\left(C_{2^{\prime \prime}}\right), 85.1\left(C_{4^{\prime}}\right), 85.0\left(C_{4^{\prime \prime}}\right), 81.7\left(C_{3^{\prime \prime}}\right), 80.6\left(C_{5^{\prime}}\right), 75.1\left(C_{2^{\prime}}\right), 71.8$ $\left(C_{3^{\prime}}\right), 53.8\left(C_{5^{\prime \prime}}\right), 42.8\left(C_{6^{\prime}}\right), 40.8\left(C_{2^{*}}\right), 36.1\left(C_{10^{*}}\right), 31.6\left(C_{9^{*}}\right), 30.3,29.8,29.7,29.6,29.6,29.4,29.3,28.9$ ( $C_{7^{\prime \prime}}$ ) , 27.0, 26.0, 25.9, 25.9, 25.9, 25.8, 25.8, 25.8, 25.8, 18.1, 8.4, 7.6, 0.1, -4.0, -4.3, -4.6; HRMS (TOF $\mathrm{MS} \mathrm{ES}^{+}$) calcd for $\mathrm{C}_{49} \mathrm{H}_{83} \mathrm{~N}_{7} \mathrm{O}_{10} \mathrm{Si}_{2}{ }^{+}(\mathrm{M}+\mathrm{H})^{+} 986,5813$ found 958.6809 .

Urea 23d. The reaction was carried out according to the general procedure for the synthesis of urea from compound 13d (13 mg, $41 \mathrm{mmol}, 1.2$ equiv.), triethylamine (19 ml, $137 \mathrm{mmol}, 4.0$ equiv.) and carbonyldiimidazole ( $7 \mathrm{mg}, 41 \mathrm{mmol}, 1.2$ equiv.) with the amine 11 ( $25 \mathrm{mg}, 34 \mathrm{mmol}, 1$ equiv.). Flash chromatography of the residue (Cyclohexane/EtOAc $=6 / 4$ ) afforded the urea $\mathbf{2 3 d}$ as a yellow oil (46 $\mathrm{mg}, 76 \%$ yield): $\mathrm{R}_{f} 0.30$ (Cyclohexane/EtOAc $=7 / 3$ ); $[\alpha]_{\mathrm{D}}-8$ (c 1.0, MeOH); IR (film); 3373, 2826, 2245, 2672, 1675, 1463, 1205, 1121, 874, 827; ${ }^{1} \mathrm{H}$ NMR $\delta 8.71$ (bs, $\left.1 \mathrm{H}, \mathrm{H}_{3}\right), 7.83-7.79\left(\mathrm{~m}, 3 \mathrm{H}, \mathrm{H}_{6} \mathrm{H}_{11^{*}}\right), 7.76$ - $7.72\left(\mathrm{~m}, 2 \mathrm{H}, \mathrm{H}_{15^{*}}\right), 7.59-7.51\left(\mathrm{~m}, 1 \mathrm{H}, \mathrm{H}_{17^{*}}\right), 7.49-7.43\left(\mathrm{~m}, 2 \mathrm{H}, \mathrm{H}_{16^{*}}\right), 6.98-6.91\left(\mathrm{~m}, 2 \mathrm{H}, \mathrm{H}_{10^{*}}\right), 5.76$ $\left(\mathrm{d}, J_{\mathrm{H}^{\prime}-\mathrm{H} 2^{\prime}}=4.3 \mathrm{~Hz}, 1 \mathrm{H}, \mathrm{H}_{1^{\prime}}\right), 5.7\left(\mathrm{dd}, J_{\mathrm{H} 5-\mathrm{H} 6}=8.1,1 \mathrm{H}, \mathrm{H}_{5}\right), 5.20\left(\mathrm{~s}, 1 \mathrm{H}, \mathrm{H}_{1^{\prime \prime}}\right), 4.60\left(\mathrm{~d}, \mathrm{~J}_{\mathrm{H}^{\prime \prime}-\mathrm{H} 2^{\prime \prime}}=5.8 \mathrm{~Hz}, 1 \mathrm{H}\right.$, 
$\left.\mathrm{H}_{3^{\prime \prime}}\right), 4.53\left(\mathrm{~d}, J_{\mathrm{H} 2^{\prime \prime}-\mathrm{H} 3^{\prime \prime}}=5.8 \mathrm{~Hz}, 1 \mathrm{H}, \mathrm{H}_{2^{\prime \prime}}\right), 4.37$ (ddd, $\left.J_{\mathrm{H}^{\prime \prime}-\mathrm{H} 5^{\prime \prime \mathrm{a}}}=6.6, J_{\mathrm{H} 4^{\prime \prime}-\mathrm{H} 5^{\prime \prime b} \mathrm{~b}}=5.0 \mathrm{~Hz}, 1 \mathrm{H}, \mathrm{H}_{4^{\prime \prime}}\right), 4.21$ (d, $J_{\mathrm{H}^{\prime}-}$ $\left.\mathrm{H}^{\prime}=4.3 \mathrm{~Hz}, 1 \mathrm{H}, \mathrm{H}_{2^{\prime}}\right), 4.12\left(\mathrm{~d}, \mathrm{~J}_{\mathrm{H}^{\prime}-\mathrm{H} 4^{\prime}}=4.7 \mathrm{~Hz}, 1 \mathrm{H}, \mathrm{H}_{3^{\prime}}\right), 4.02\left(\mathrm{t}, \mathrm{J}_{\mathrm{H}^{*}-\mathrm{H} 7^{*}}=9.2 \mathrm{~Hz}, 2 \mathrm{H}, \mathrm{H}_{8^{*}}\right), 4.01-3.99(\mathrm{~m}, 1$ $\left.\mathrm{H}, \mathrm{H}_{4^{\prime}}\right), 3.87-3.81\left(\mathrm{~m}, 1 \mathrm{H}, \mathrm{H}_{5^{\prime}}\right), 3.67-3.58\left(\mathrm{~m}, 1 \mathrm{H}, \mathrm{H}_{6^{\prime} \mathrm{a}}\right), 3.56-3.44\left(\mathrm{~m}, 2 \mathrm{H}, \mathrm{H}_{5^{\prime \prime}}\right), 3.41-3.35(\mathrm{~m}, 1 \mathrm{H}$, $\left.\mathrm{H}_{6^{\prime} \mathrm{b}}\right), 3.15\left(\mathrm{t}, \mathrm{J}_{\mathrm{H}^{*} \mathrm{H}^{*}}=6.1 \mathrm{~Hz}, 2 \mathrm{H}, \mathrm{H}_{1^{*}}\right), 1.88-1.76\left(\mathrm{~m}, 2 \mathrm{H}, \mathrm{H}_{7^{*}}\right), 1.73-1.65\left(\mathrm{~m}, 4 \mathrm{H}, \mathrm{H}_{7^{\prime \prime}}, \mathrm{H}_{3^{*}}\right), 1.66-$ $1.61\left(\mathrm{~m}, 2 \mathrm{H}, \mathrm{H}_{7^{\prime \prime} \mathrm{b}}\right), 1.59-1.52\left(\mathrm{~m}, 4 \mathrm{H}, \mathrm{H}_{5^{*}}, \mathrm{H}_{6^{*}}\right), 1.39-1.22\left(\mathrm{~m}, 8 \mathrm{H}, \mathrm{H}_{8^{\prime \prime}} \mathrm{H}_{4^{*}}\right), 0.94-0.79(\mathrm{~m}, 18 \mathrm{H}$, $\left.\mathrm{C}\left(\mathrm{CH}_{3}\right)_{3}\right), 0.19-0.01\left(\mathrm{~m}, 12 \mathrm{H}, \mathrm{SiCH}_{3}\right) ;{ }^{13} \mathrm{C}$ NMR $\delta 195.7\left(\mathrm{C}_{13^{*}}\right), 163.0\left(\mathrm{C}_{9^{*}}\right), 162.9\left(\mathrm{C}_{4}\right), 158.3\left(\mathrm{C}_{8^{\prime}}\right), 150.1$ $\left(C_{2}\right), 140.5\left(C_{6}\right), 138.5\left(C_{14^{*}}\right), 132.7\left(C_{11^{*}}\right), 132.0\left(C_{17^{*}}\right), 130.1\left(C_{12^{*}}\right), 129.8\left(C_{15^{*}}\right), 128.3\left(C_{16^{*}}\right), 118.2\left(C_{6^{\prime \prime}}\right)$, 114.2 $\left(C_{10^{*}}\right), 112.0\left(C_{1^{\prime \prime}}\right), 101.7\left(C_{5}\right), 89.7\left(C_{1^{\prime}}\right), 86.0\left(C_{2^{\prime \prime}}\right), 85.1\left(C_{3^{\prime}}\right), 85.0\left(C_{4^{\prime \prime}}\right), 81.7\left(C_{3^{\prime \prime}}\right), 80.5\left(C_{5^{\prime}}\right), 75.1$ $\left(C_{2^{\prime}}\right), 71.8\left(C_{4^{\prime}}\right), 68.3\left(C_{8^{*}}\right), 63.4,53.8\left(C_{5^{\prime \prime}}\right), 42.7\left(C_{6^{\prime}}\right), 40.8\left(C_{1^{*}}\right), 30.3,29.8,29.4,29.3,29.3,29.2\left(C_{7^{\prime \prime}}\right)$, 28.9, $28.5\left(C_{7^{\prime \prime}}\right), 26.9,26.0,26.0,25.9,25.9,25.8,25.8,25.8,18.1,8.5,8.5,8.3,7.6,-4.0,-4.4,-4.7$; HRMS APCl+ calcd for $\mathrm{C}_{54} \mathrm{H}_{84} \mathrm{~N}_{7} \mathrm{O}_{12} \mathrm{Si}_{2}{ }^{+}(\mathrm{M}+\mathrm{H})^{+} 1078,5711$ found 1078.5711 .

Urea 23e. The reaction was carried out according to the general procedure for the synthesis of urea from compound 13e ( $24.6 \mathrm{mg}, 83 \mathrm{mmol}, 1.2$ equiv.), triethylamine ( $38 \mathrm{~mL}, 206 \mathrm{mmol}, 4.0$ equiv.) and carbonyldiimidazole (13.4 mg, $83 \mathrm{mmol}, 1.2$ equiv.) with the amine 11 (50 mg, $69 \mathrm{mmol}, 1$ equiv.). Flash chromatography of the residue (Cyclohexane/EtOAc $=6 / 4$ ) afforded the urea 23e as a colorless oil (33 mg, 40\% yield): $\mathbf{R}_{f} 0.40$ (Cyclohexane/EtOAc $=7 / 3$ ); [ $\left.\alpha\right]_{D}-11$ (c 1.0, MeOH); IR (film): 2931, 2929, 2912, 2106, 1697, 1565, 1403, 1378, 1275, 1260, 1167, 1100, 926, 866, 840, 764, 750; ${ }^{1} \mathrm{H}$ NMR $\delta 8.32$ $(\mathrm{s}, 1 \mathrm{H}, \mathrm{NH}), 7.81\left(\mathrm{~d}, J_{\mathrm{HG}-\mathrm{H} 5}=8.2 \mathrm{~Hz}, 1 \mathrm{H}, \mathrm{H}_{6}\right), 5.76\left(\mathrm{~d}, J_{\mathrm{H}^{\prime}-\mathrm{H} 2^{\prime}}=4.1 \mathrm{~Hz}, 1 \mathrm{H}, \mathrm{H}_{1^{\prime}}\right), 5.69\left(\mathrm{~d}, J_{\mathrm{H} 5-\mathrm{H} 6}=8.2 \mathrm{~Hz}, 1\right.$ $\left.\mathrm{H}, \mathrm{H}_{5}\right), 5.20\left(\mathrm{~s}, 1 \mathrm{H}, \mathrm{H}_{1^{\prime \prime}}\right), 4.60\left(\mathrm{~d}, J_{\mathrm{H} 3^{\prime \prime}-\mathrm{H} 2^{\prime \prime}}=6.2,1 \mathrm{H}, \mathrm{H}_{3^{\prime \prime}}\right), 4.52\left(\mathrm{~d}, J_{\mathrm{H} 2^{\prime \prime}-\mathrm{H} 3^{\prime \prime}}=6.2 \mathrm{~Hz}, 1 \mathrm{H}, \mathrm{H}_{2^{\prime \prime}}\right), 4.37$ (dd, $J_{\mathrm{H}^{\prime \prime}-}$ $\left.\mathrm{H}^{\prime \prime}=8.4 \mathrm{~Hz}, 1 \mathrm{H}, \mathrm{H}_{4^{\prime \prime}}\right), 4.20\left(\mathrm{t}, \mathrm{J}_{\mathrm{H}^{\prime}-\mathrm{H} 1^{\prime}}=4.1 \mathrm{~Hz}, 1 \mathrm{H}, \mathrm{H}_{2^{\prime}}\right), 4.15-4.09\left(\mathrm{~m}, 1 \mathrm{H}, \mathrm{H}_{4^{\prime}}\right), 4.00\left(\mathrm{t}, \mathrm{J}_{\mathrm{H}^{\prime}}-\mathrm{H}^{\prime}=4.5 \mathrm{~Hz}\right.$, $\left.1 \mathrm{H}, \mathrm{H}_{3^{\prime}}\right), 3.84\left(\mathrm{t}, J_{\mathrm{H5^{ \prime }}-\mathrm{H6^{ \prime }}}=5.7 \mathrm{~Hz}, 1 \mathrm{H}, \mathrm{H}_{5^{\prime}}\right), 3.62\left(\mathrm{dd}, J_{\mathrm{HG}^{\prime} \mathrm{a}-\mathrm{H6^{ \prime } \mathrm { b }}}=13.5, J_{\mathrm{H}^{\prime} \mathrm{a}-\mathrm{H} 5^{\prime}}=5.7 \mathrm{~Hz}, 1 \mathrm{H}, \mathrm{H}_{6^{\prime} \mathrm{a}}\right), 3.49$ (ddd, $\left.J_{H\left(" \mathrm{a}-\mathrm{H} 5^{\prime \prime} \mathrm{b}\right.}=16.6, J_{\mathrm{H} 5^{\prime \prime} \mathrm{a}-\mathrm{H} 4^{\prime \prime}}=J_{\mathrm{H} 5^{\prime \prime} \mathrm{b}-\mathrm{H} 4^{\prime \prime}}=4.4 \mathrm{~Hz}, 2 \mathrm{H}, \mathrm{H}_{5^{\prime \prime}}\right), 3.45-3.40\left(\mathrm{~m}, 1 \mathrm{H}, \mathrm{H}_{4^{*}}\right), 3.41-3.34\left(\mathrm{~m}, 1 \mathrm{H}, \mathrm{H}_{6^{\prime} \mathrm{b}}\right)$, $3.17\left(\mathrm{tdd}, J_{\mathrm{H}^{*} \mathrm{a}-\mathrm{H} 2^{*} \mathrm{~b}}=20.7, J_{\mathrm{H}_{2} \mathrm{a}^{*}-\mathrm{H} 3^{*}}=J_{\mathrm{H}^{*} \mathrm{~b}-\mathrm{H} 3^{*}}=6.5 \mathrm{~Hz}, 2 \mathrm{H}, \mathrm{H}_{2^{*}}\right), 1.69\left(\mathrm{q}, J_{\mathrm{H} 7^{\prime \prime} \mathrm{a}-\mathrm{H} 8^{\prime \prime}}=7.3 \mathrm{~Hz}, 2 \mathrm{H}, \mathrm{H}_{7^{\prime \prime} \mathrm{a}}\right), 1.58$ - $1.42\left(\mathrm{~m}, 4 \mathrm{H}, \mathrm{H}_{7^{\prime \prime} \mathrm{b}}, \mathrm{H}_{3^{*}}\right), 1.39-1.17(\mathrm{~m}, 14 \mathrm{H}), 1.17-1.09(\mathrm{~m}, 20 \mathrm{H}), 1.05(\mathrm{~m}, 6 \mathrm{H}), 0.95-0.77(\mathrm{~m}, 39 \mathrm{H})$, $0.14-0.01\left(\mathrm{~m}, 12 \mathrm{H}, \mathrm{SiCH}_{3}\right) ;{ }^{13} \mathrm{C}$ NMR $\delta 163.0\left(\mathrm{C}_{4}\right), 158.2\left(\mathrm{C}_{8^{\prime}}\right), 150.1\left(\mathrm{C}_{2}\right), 140.5\left(\mathrm{C}_{6}\right), 118.2\left(\mathrm{C}_{6^{\prime \prime}}\right), 112.1$ $\left(C_{1^{\prime \prime}}\right), 101.8\left(C_{5}\right), 89.8\left(C_{1^{\prime}}\right), 86.0\left(C_{2^{\prime \prime}}\right), 85.1\left(C_{4^{\prime \prime}}\right), 85.0\left(C_{4^{\prime}}\right), 81.7\left(C_{3^{\prime \prime}}\right), 80.7\left(C_{5^{\prime}}\right), 75.1\left(C_{2^{\prime}}\right), 71.8\left(C_{3^{\prime}}\right), 53.8$ $\left(C_{5^{\prime \prime}}\right), 50.8\left(C_{4^{*}}\right), 42.8\left(C_{8^{\prime}}\right), 39.5\left(C_{2^{*}}\right), 39.0,38.9,37.6,37.6,37.5,37.5,37.5,37.4,37.4,32.9,30.8,29.3$ $\left(C_{7^{\prime \prime}}\right), 29.0\left(C_{7^{\prime \prime}}\right), 28.0,25.9,25.9,25.9,25.9,25.8,25.8,25.7,24.9,24.6,24.5,22.8,22.7,22.7,19.8$, 19.8, 19.7, 19.5, 19.5, 18.1, 8.4, 7.6, -4.0, -4.3, -4.6; HRMS (TOF MS ES ${ }^{+}$) calcd for $\mathrm{C}_{53} \mathrm{H}_{99} \mathrm{~N}_{7} \mathrm{O}_{10} \mathrm{Si}_{2}{ }^{+}(\mathrm{M}+$ $\mathrm{H})^{+}$1050.7065, found 1050.7095 .

Urea 23f. The reaction was carried out according to the general procedure for the synthesis of urea from 2-(naphthalen-2-yl)ethan-1-amine (17.14 mg, $83 \mathrm{mmol}, 1.2$ equiv.), triethylamine ( $38 \mathrm{~mL}, 206$ mmol, 4.0 equiv.) and carbonyldiimidazole ( $13.4 \mathrm{mg}, 83 \mathrm{mmol}, 1.2$ equiv.) with the amine 12 (50 mg, $69 \mathrm{mmol}, 1$ equiv.). Flash chromatography of the residue (Cyclohexane/EtOAc $=6 / 4)$ afforded the urea $23 \mathrm{f}$ as a colorless oil (42 mg, 73\% yield): $\mathrm{R}_{f} 0.40$ (Cyclohexane/EtOAc $\left.=6 / 4\right) ;[\alpha]_{\mathrm{D}}-16\left(c 1.0, \mathrm{CH}_{2} \mathrm{Cl}_{2}\right)$; IR (film): 3726, 3627, 2389s, 2342, 1698, 1054; ${ }^{1} \mathrm{H}$ NMR $\delta 8.87(\mathrm{~s}, 1 \mathrm{H}, \mathrm{NH}), 7.49-7.40(\mathrm{~m}, 4 \mathrm{H}$, $\left.\mathrm{H}_{6^{*}} \mathrm{H}_{8^{*}} \mathrm{H}_{11^{*}} \mathrm{H}_{6}\right), 7.63\left(\mathrm{~s}, 1 \mathrm{H}, \mathrm{H}_{13^{*}}\right), 7.48-7.41\left(\mathrm{~m}, 2 \mathrm{H}, \mathrm{H}_{9^{*}} \mathrm{H}_{10^{*}}\right), 7.33\left(\mathrm{~d}, \mathrm{~J}_{\mathrm{H}^{*}-\mathrm{H}^{*}}=8.3 \mathrm{~Hz}, 1 \mathrm{H}, \mathrm{H}_{5^{*}}\right), 5.68(\mathrm{~d}$, $\left.J_{H 1^{\prime}-H 2^{\prime}}=3.7 \mathrm{~Hz}, 1 \mathrm{H}, \mathrm{H}_{1^{\prime}}\right), 5.66\left(\mathrm{~d}, J_{\mathrm{H} 5-\mathrm{H} 6}=8.2 \mathrm{~Hz}, 1 \mathrm{H}, \mathrm{H}_{5}\right), 5.18\left(\mathrm{~s}, 1 \mathrm{H}, \mathrm{H}_{1^{\prime \prime}}\right), 4.56\left(\mathrm{~d}, \mathrm{JH}_{\mathrm{H}^{\prime \prime}-\mathrm{H} 2^{\prime \prime}}=6.5 \mathrm{~Hz}, 1 \mathrm{H}\right.$, $\left.\mathrm{H}_{3^{\prime \prime}}\right), 4.49\left(\mathrm{~d}, \mathrm{~J}_{\mathrm{H} 2^{\prime \prime}-\mathrm{H} 3^{\prime \prime}}=6.5 \mathrm{~Hz}, 1 \mathrm{H}, \mathrm{H}_{2^{\prime \prime}}\right), 4.29\left(\mathrm{t}, J_{\mathrm{H} 4^{\prime \prime}-\mathrm{H} 5^{\prime \prime}}=5.6 \mathrm{~Hz}, 1 \mathrm{H}, \mathrm{H}_{4^{\prime \prime}}\right), 4.18\left(\mathrm{t}, J_{\mathrm{H} 2^{\prime}-\mathrm{H} 1^{\prime}}=3.7 \mathrm{~Hz}, 1 \mathrm{H}\right.$, $\left.\mathrm{H}_{2^{\prime}}\right), 4.11\left(\mathrm{~s}, 1 \mathrm{H}, \mathrm{H}_{3^{\prime}}\right), 3.99-3.84\left(\mathrm{~m}, 1 \mathrm{H}, \mathrm{H}_{4^{\prime}}\right), 3.82\left(\mathrm{~s}, 1 \mathrm{H}, \mathrm{H}_{5^{\prime}}\right), 3.63-3.51\left(\mathrm{~m}, 5 \mathrm{H}, \mathrm{H}_{6^{\prime}} \mathrm{H}_{5^{\prime \prime}} \mathrm{H}_{3^{*}}\right), 3.36(\mathrm{~d}$, $\left.J_{\mathrm{H}^{\prime} \mathrm{b}-\mathrm{NH}}=4.8 \mathrm{~Hz}, 1 \mathrm{H}, \mathrm{H}_{6^{\prime} \mathrm{b}}\right), 2.97\left(\mathrm{t}, J_{\mathrm{H}^{*}-\mathrm{H} 3^{*}}=6.7 \mathrm{~Hz}, 2 \mathrm{H}, \mathrm{H}_{2^{*}}\right), 1.69$ (q, $J_{\mathrm{H}^{\prime \prime} \mathrm{a}-\mathrm{H} 8^{\prime \prime}}=7.3 \mathrm{~Hz}, 2 \mathrm{H}, \mathrm{H}_{7^{\prime \prime} \mathrm{a}}$ ), 1.54 (q, $\left.J_{H 7^{\prime \prime b}-H 8^{\prime \prime}}=7.3 \mathrm{~Hz}, 2 \mathrm{H}, \mathrm{H}_{7^{\prime \prime} \mathrm{b}}\right), 0.88\left(\mathrm{~m}, 24 \mathrm{H},-\mathrm{C}\left(\mathrm{CH}_{3}\right)_{3}, \mathrm{H}_{8^{\prime \prime}}\right), 0.01\left(\mathrm{~m}, 12 \mathrm{H}, \mathrm{SiCH}_{3}\right) ;{ }^{13} \mathrm{C} \mathrm{NMR} \delta 163.2\left(\mathrm{C}_{4}\right)$, $158.0\left(C_{8^{\prime}}\right), 150.1\left(C_{2}\right), 140.4\left(C_{6}\right), 136.7\left(C_{4^{*}}\right), 133.7\left(C_{7^{*}}\right), 132.3\left(C_{12^{*}}\right), 128.4\left(C_{6^{*}}\right), 127.7\left(C_{8^{*}}\right), 127.5$ $\left(C_{11^{*}}\right), 127.3\left(C_{13^{*}}\right), 127.2\left(C_{5^{*}}\right), 126.3\left(C_{9^{*}}\right), 125.6\left(C_{10^{*}}\right), 118.1\left(C_{6^{\prime \prime}}\right), 112.0\left(C_{1^{\prime \prime}}\right), 101.7\left(C_{5}\right), 89.8\left(C_{1^{\prime}}\right)$, $85.9\left(C_{2^{\prime \prime}}\right), 84.9\left(C_{3^{\prime}}\right), 84.9\left(C_{4^{\prime \prime}}\right), 81.6\left(C_{3^{\prime \prime}}\right), 80.4\left(C_{5^{\prime}}\right), 75.1\left(C_{2^{\prime}}\right), 71.6\left(C_{4^{\prime}}\right), 53.7\left(C_{5^{\prime \prime}}\right), 42.7\left(C_{6^{\prime}}\right), 41.6\left(C_{3^{*}}\right)$, 
$36.7\left(C_{2^{*}}\right), 29.2\left(C_{7^{\prime \prime}}\right)$ a, $28.9\left(C_{7^{\prime \prime}}\right), 25.9,25.90,18.0,8.4,7.6,-4.0,-4.3,-4.7,-4.7 ;$ HRMS (TOF MS ES ${ }^{+}$) calcd for $\mathrm{C}_{45} \mathrm{H}_{69} \mathrm{~N}_{7} \mathrm{O}_{10} \mathrm{Si}_{2}{ }^{+}(\mathrm{M}+\mathrm{H})^{+}$924.4717, found 924.4758 .

Urea 23g. The reaction was carried out according to the general procedure for the synthesis of urea from 3-(4-chlorophenyl)propan-1-amine $(14.0 \mathrm{mg}, 83 \mathrm{mmol}, 1.2$ equiv.), triethylamine ( $38 \mathrm{~mL}, 206$ mmol, 4.0 equiv.) and carbonyldiimidazole (13.4 mg, $83 \mathrm{mmol}, 1.2$ equiv.) with the amine 11 (50 mg, $69 \mathrm{mmol}, 1$ equiv.). Flash chromatography of the residue (Cyclohexane/EtOAc $=6 / 4$ ) afforded the urea 23g as a colorless oil ( $42 \mathrm{mg}, 66 \%$ yield): $\mathrm{R}_{f} 0.45$ (Cyclohexane/EtOAc $\left.=6 / 4\right) ;[\alpha]_{\mathrm{D}}-14\left(c 1.0, \mathrm{CH}_{2} \mathrm{Cl}_{2}\right.$ ); IR (film): 3372, 2930, 2857, 2105, 1693, 1561, 1492, 1462, 1378, 1260, 1166, 1092, 1014, 924, 866, 850, 813, 777; ${ }^{1} \mathrm{H}$ NMR $\delta 8.88(\mathrm{~s}, 1 \mathrm{H}, \mathrm{NH}), 7.83\left(\mathrm{~d}, J_{\mathrm{H} 6-\mathrm{H} 5}=8.1 \mathrm{~Hz}, 1 \mathrm{H}, \mathrm{H}_{6}\right), 7.27\left(\mathrm{~d}, J_{\mathrm{H} 6^{*}-\mathrm{H} 7^{*}}=7.8 \mathrm{~Hz}, 2 \mathrm{H}, \mathrm{H}_{6^{*}}\right)$, $7.13\left(\mathrm{~d}, J_{\mathrm{H}^{*}-\mathrm{H} 6^{*}}=7.8 \mathrm{~Hz}, 2 \mathrm{H}, \mathrm{H}_{7^{*}}\right), 5.78\left(\mathrm{~d}, J_{\mathrm{H} 1^{\prime}-\mathrm{H} 2^{\prime}}=3.4 \mathrm{~Hz}, 1 \mathrm{H}, \mathrm{H}_{1^{\prime}}\right), 5.73\left(\mathrm{~d}, J_{\mathrm{H} 5-\mathrm{H} 6}=8.1 \mathrm{~Hz}, 1 \mathrm{H}, \mathrm{H}_{5}\right), 5.23$ $\left(\mathrm{s}, 1 \mathrm{H}, \mathrm{H}_{1^{\prime \prime}}\right), 4.63\left(\mathrm{~d}, J_{\mathrm{H} 3^{\prime \prime}-\mathrm{H} 2^{\prime \prime}}=6.1 \mathrm{~Hz}, 1 \mathrm{H}, \mathrm{H}_{3^{\prime \prime}}\right), 4.56$ (d, $\left.J_{\mathrm{H} 2^{\prime \prime}-\mathrm{H} 3^{\prime \prime}}=6.1 \mathrm{~Hz}, 1 \mathrm{H}, \mathrm{H}_{2^{\prime \prime}}\right), 4.40$ (d, $J_{\mathrm{H} 4^{\prime \prime}-\mathrm{H} 5^{\prime \prime}}=5.5$ $\left.\mathrm{Hz}, 1 \mathrm{H}, \mathrm{H}_{4^{\prime \prime}}\right), 4.25\left(\mathrm{~s}, J_{\mathrm{H}^{\prime}-\mathrm{H} 1^{\prime}}=3.4 \mathrm{~Hz}, 1 \mathrm{H}, \mathrm{H}_{2^{\prime}}\right), 4.19-4.15\left(\mathrm{~m}, 1 \mathrm{H}, \mathrm{H}_{3^{\prime}}\right), 4.03\left(\mathrm{t}, J_{\mathrm{H}^{\prime}}-\mathrm{H} 5^{\prime}=3.9 \mathrm{~Hz}, 1 \mathrm{H}, \mathrm{H}_{4^{\prime}}\right)$, $3.91-3.82\left(\mathrm{~m}, 1 \mathrm{H}, \mathrm{H}_{5^{\prime}}\right), 3.66\left(\mathrm{~d}, J_{\mathrm{H} 6^{\prime} \mathrm{a}-\mathrm{H} 5^{\prime}}=5.8 \mathrm{~Hz}, 1 \mathrm{H}, \mathrm{H}_{6^{\prime} \mathrm{a}}\right), 3.52\left(\mathrm{ddd}, J_{\mathrm{H} 5^{\prime \prime} \mathrm{a}-\mathrm{H} 5^{\prime \prime b}}=19.6, J_{H 5^{\prime \prime} \mathrm{a}-\mathrm{H} 4^{\prime \prime}}=J_{\mathrm{H} 5^{\prime \prime} \mathrm{b}-\mathrm{H} 4^{\prime \prime}}\right.$ $\left.=5.5 \mathrm{~Hz}, 2 \mathrm{H}, \mathrm{H}_{5^{\prime \prime}}\right), 3.43-3.35\left(\mathrm{~m}, 1 \mathrm{H}, \mathrm{H}_{6^{\prime} \mathrm{b}}\right), 3.22\left(\mathrm{t}, J_{\mathrm{H}^{*}-\mathrm{H} 3^{*}}=6.4 \mathrm{~Hz}, 2 \mathrm{H}, \mathrm{H}_{2^{*}}\right), 2.65\left(\mathrm{t}, J_{\mathrm{H}^{*}-\mathrm{H} 3^{*}}=7.6 \mathrm{~Hz}\right.$,

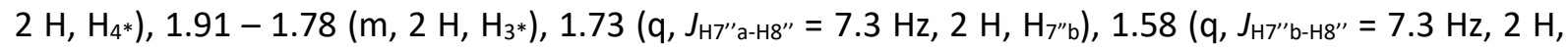
$\left.\mathrm{H}_{7^{\prime \prime}} \mathrm{b}\right), 1.03-0.80\left(\mathrm{~m}, 24 \mathrm{H},-\mathrm{C}\left(\mathrm{CH}_{3}\right)_{3}, \mathrm{H}_{8^{\prime \prime}}\right), 0.12\left(\mathrm{~m}, 12 \mathrm{H}, \mathrm{SiCH}_{3}\right) ;{ }^{13} \mathrm{C}$ NMR $\delta 163.1\left(\mathrm{C}_{4}\right), 158.1\left(\mathrm{C}_{8^{\prime}}\right), 150.2$ $\left(C_{2}\right), 140.5\left(C_{6}\right), 140.1\left(C_{8^{*}}\right), 131.8\left(C_{5^{*}}\right), 129.8\left(C_{6^{*}}\right), 128.6\left(C_{7^{*}}\right), 118.2\left(C_{6^{\prime \prime}}\right), 112.1\left(C_{1^{\prime \prime}}\right), 101.8\left(C_{5}\right), 89.9$ $\left(C_{1^{\prime}}\right), 85.9\left(C_{2^{\prime \prime}}\right), 85.1\left(C_{3^{\prime}}\right), 85.0\left(C_{4^{\prime \prime}}\right), 81.7\left(C_{3^{\prime \prime}}\right), 80.6\left(C_{5^{\prime}}\right), 75.1\left(C_{2^{\prime}}\right), 71.7\left(C_{4^{\prime}}\right), 53.9\left(C_{5^{\prime \prime}}\right), 42.8\left(C_{6^{\prime}}\right), 40.1$ $\left(C_{1^{*}}\right), 32.6\left(C_{4^{*}}\right), 32.0\left(C_{3^{*}}\right), 29.8\left(C_{7^{\prime \prime}}\right), 29.3\left(C_{7^{\prime \prime}}\right), 28.9,25.9,25.9,18.0,8.4,7.6,-4.0,-4.3,-4.7,-4.7$; HRMS (TOF MS ES ${ }^{+}$) calcd for $\mathrm{C}_{42} \mathrm{H}_{68} \mathrm{Cl}_{1} \mathrm{~N}_{7} \mathrm{O}_{10} \mathrm{Si}_{2}{ }^{+}(\mathrm{M}+\mathrm{H})^{+}$922.4327, found 922.4337.

Urea $\mathbf{2 3 h}$. The reaction was carried out according to the general procedure for the synthesis of urea

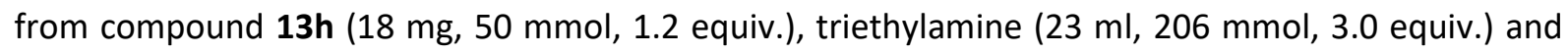
carbonyldiimidazole ( $8 \mathrm{mg}, 50 \mathrm{mmol}, 1.2$ equiv.) with the amine 11 ( $30 \mathrm{mg}, 41 \mathrm{mmol}, 1$ equiv.). Flash chromatography of the residue (Cyclohexane/EtOAc $=4 / 6$ ) afforded the urea $\mathbf{2 3 h}$ as a yellow oil (46 $\mathrm{mg}, 47 \%$ yield): $\mathrm{R}_{f} 0.45$ (Cyclohexane/EtOAc $=7 / 3$ ); [ $\left.\alpha\right]_{D}-7$ (c 1.0, MeOH); IR (film): 2929, 2857, 2105, $1697,1568,1463,1378,1275,1167,1098,926,869,839,764,750 ;{ }^{1} \mathrm{H}$ NMR $\delta 7.79$ (d, J J6-H5 $=8.2 \mathrm{~Hz}, 1$ $\left.\mathrm{H}, \mathrm{H}_{6}\right), 5.81\left(\mathrm{~d}, J_{\mathrm{H}^{\prime}-\mathrm{H} 2^{\prime}}=4.7 \mathrm{~Hz}, 1 \mathrm{H}, \mathrm{H}_{1^{\prime}}\right), 5.71\left(\mathrm{~d}, J_{\mathrm{H} 5-\mathrm{H} 6}=8.2 \mathrm{~Hz}, 1 \mathrm{H}, \mathrm{H}_{5}\right), 5.21\left(\mathrm{~s}, 1 \mathrm{H}, \mathrm{H}_{1^{\prime \prime}}\right), 4.62\left(\mathrm{~d}, J_{\mathrm{H}^{\prime \prime}-}\right.$ $\left.\mathrm{H}^{\prime \prime}=6.2 \mathrm{~Hz}, 1 \mathrm{H}, \mathrm{H}_{3^{\prime \prime}}\right), 4.53\left(\mathrm{~d}, J_{\mathrm{H} 2^{\prime \prime}-\mathrm{H} 3^{\prime \prime}}=6.2 \mathrm{~Hz}, 1 \mathrm{H}, \mathrm{H}_{2^{\prime \prime}}\right), 4.41-4.34\left(\mathrm{~m}, 1 \mathrm{H}, \mathrm{H}_{4^{\prime \prime}}\right), 4.22-4.17(\mathrm{~m}, 1 \mathrm{H}$,

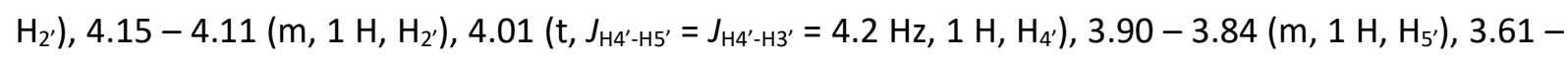
$3.58\left(\mathrm{~m}, 1 \mathrm{H}, \mathrm{H}_{6^{\prime} \mathrm{a}}\right), 3.56-3.47\left(\mathrm{~m}, 2 \mathrm{H}, \mathrm{H}_{5^{\prime \prime}}\right), 3.42-3.35\left(\mathrm{~m}, 1 \mathrm{H}, \mathrm{H}_{6^{\prime} \mathrm{b}}\right), 3.15\left(\mathrm{dt}, \mathrm{J}_{\mathrm{H}^{*} \mathrm{a}-\mathrm{H} 2^{*} \mathrm{~b}}=12.7, J_{\mathrm{H}^{*}-\mathrm{H}^{*}}\right.$ $\left.=6.5 \mathrm{~Hz}, 2 \mathrm{H}, \mathrm{H}_{2^{*}}\right), 1.70$ (q, $\left.J_{\mathrm{H} 7^{\prime \prime} \mathrm{a}-\mathrm{H} 8^{\prime \prime}}=7.4 \mathrm{~Hz}, 2 \mathrm{H}, \mathrm{H}_{7^{\prime \prime} \mathrm{a}}\right), 1.55$ (q, $\left.J_{\mathrm{H} 7^{\prime \prime} \mathrm{b}-\mathrm{H} 8^{\prime \prime}}=7.3 \mathrm{~Hz}, 2 \mathrm{H}, \mathrm{H}_{7^{\prime \prime} \mathrm{b}}\right), 1.50-1.46$ $\left(\mathrm{m}, 2 \mathrm{H}, \mathrm{H}_{3^{*}}\right), 1.27(\mathrm{~m}, 21 \mathrm{H}), 0.95-0.81(\mathrm{~m}, 22 \mathrm{H}), 0.08\left(\mathrm{~m}, 12 \mathrm{H}, \mathrm{SiCH}_{3}\right) ;{ }^{13} \mathrm{C} \mathrm{NMR} \delta 162.8\left(\mathrm{C}_{4}\right), 158.4$ $\left(C_{8^{\prime}}\right), 150.1\left(C_{2}\right), 140.5\left(C_{6}\right), 118.2\left(C_{6^{\prime \prime}}\right), 111.9\left(C_{1^{\prime \prime}}\right), 102.0\left(C_{5}\right), 86.0\left(C_{2^{\prime \prime}}\right), 85.4\left(C_{4^{\prime}}\right), 84.9\left(C_{4^{\prime \prime}}\right), 81.8\left(C_{3^{\prime \prime}}\right)$, $75.2\left(C_{2^{\prime}}\right), 72.2\left(C_{3^{\prime}}\right), 53.7\left(C_{5^{\prime \prime}}\right), 42.6\left(C_{6^{\prime}}\right), 40.4\left(C_{2^{*}}\right)$ 31.9, $29.8\left(C_{3^{*}}\right), 29.3\left(C_{7^{\prime \prime}}\right), 29.3\left(C_{7^{\prime \prime} b}\right), 29.0,25.9$, 25.8, 25.7, 25.7, 25.6, 25.6, 25.6, 25.6, 25.6, 25.5, 25.5, 25.5, 25.5, 25.4, 25.4, 25.4, 25.4, 25.4, 25.3, 25.3, 22.7, 18.1, 18.0, 14.1, 8.4, 7.6, -4.0, -4.4, -4.6; $\mathrm{HRMS} \mathrm{APCl}{ }^{+}$calcd for $\mathrm{C}_{57} \mathrm{H}_{109} \mathrm{~N}_{8} \mathrm{O}_{10} \mathrm{Si}_{2}{ }^{+}(\mathrm{M}+\mathrm{H})^{+}$ 1121,7800 found 1121.78157 .

Urea 23i. The reaction was carried out according to the general procedure for the synthesis of urea with compound $13 \mathrm{i}$ ( $22.6 \mathrm{mg}, 83 \mathrm{mmol}, 1.2$ equiv.), triethylamine ( $38 \mathrm{~mL}, 206 \mathrm{mmol}, 4.0$ equiv.) and carbonyldiimidazole (13.4 mg, 83mmol, 1.2 equiv.) with the amine $11(50 \mathrm{mg}, 69 \mathrm{mmol}, 1$ equiv.). Flash chromatography of the residue ( $\mathrm{DCM} / \mathrm{MeOH}=6 / 4)$ afforded the urea $\mathbf{2 3 i}$ as a colorless oil $(19 \mathrm{mg}, 45 \%$ yield): $\mathbf{R}_{f} 0.25$ (DCM/MeOH = 98/2); $[\alpha]_{D}-16$ (c 1.0, MeOH); IR (film) 2931, 2857, 2106, 1695, 1613, $1556,1462,1382,1328,1275,1260,1168,1116,1052,839,764,750 ;{ }^{1} \mathrm{H}$ NMR $\delta 8.61$ (s, $\left.1 \mathrm{H}, \mathrm{N} \mathrm{H}\right), 8.40$ $\left(\mathrm{s}, 1 \mathrm{H}, \mathrm{H}_{10^{*}}\right), 7.78\left(\mathrm{~d}, \mathrm{~J}_{\mathrm{H} 6-\mathrm{H} 5^{\prime}}=8.2 \mathrm{~Hz}, 1 \mathrm{H}, \mathrm{H}_{6}\right), 7.64\left(\mathrm{~d}, \mathrm{~J}_{\mathrm{H} 12^{*}-\mathrm{H} 13^{*}}=8.9 \mathrm{~Hz}, 1 \mathrm{H}, \mathrm{H}_{12^{*}}\right), 6.64\left(\mathrm{~d}, \mathrm{~J}_{\mathrm{H} 13^{*}-\mathrm{H} 12^{*}}=8.9\right.$ $\left.\mathrm{Hz}, 1 \mathrm{H}, \mathrm{H}_{13^{*}}\right), 5.77\left(\mathrm{~d}, J_{\mathrm{H} 1^{\prime}-\mathrm{H} 2^{\prime}}=4.6 \mathrm{~Hz}, 1 \mathrm{H}, \mathrm{H}_{1^{\prime}}\right), 5.71\left(\mathrm{~d}, J_{\mathrm{H} 5-\mathrm{H} 6}=8.2 \mathrm{~Hz}, 1 \mathrm{H}, \mathrm{H}_{5}\right), 5.22\left(\mathrm{~s}, 1 \mathrm{H}, \mathrm{H}_{1^{\prime \prime}}\right), 4.61$ $\left(\mathrm{dd}, J_{\mathrm{H}^{\prime \prime}-\mathrm{H} 2^{\prime \prime}}=6.2 \mathrm{~Hz}, 1 \mathrm{H}, \mathrm{H}_{3^{\prime \prime}}\right), 4.53\left(\mathrm{~d}, J_{\mathrm{H} 2^{\prime \prime}-\mathrm{H} 3^{\prime \prime}}=6.2 \mathrm{~Hz}, 1 \mathrm{H}, \mathrm{H}_{2^{\prime \prime}}\right), 4.39\left(\mathrm{t}, J_{\mathrm{H} 4^{\prime \prime}-\mathrm{H} 5^{\prime \prime}}=8.1 \mathrm{~Hz}, 1 \mathrm{H}, \mathrm{H}_{4^{\prime \prime}}\right), 4.23$ 
(d, $\left.J_{\mathrm{H}^{\prime}-\mathrm{H} 3^{\prime}}=4.6 \mathrm{~Hz}, 1 \mathrm{H}, \mathrm{H}_{2^{\prime}}\right), 4.14-4.10\left(\mathrm{~m}, 1 \mathrm{H}, \mathrm{H}_{3^{\prime}}\right), 4.05-4.0\left(\mathrm{~m}, 1 \mathrm{H}, \mathrm{H}_{4^{\prime}}\right), 3.87\left(\mathrm{t}, J_{\mathrm{H} 5^{\prime}-\mathrm{H} 6^{\prime}}=6.9 \mathrm{~Hz}, 1 \mathrm{H}\right.$, $\left.\mathrm{H}_{5^{\prime}}\right), 3.70\left(\mathrm{~s}, 4 \mathrm{H}, \mathrm{H}_{6^{*}}\right), 3.64-3.61\left(\mathrm{~m}, 1 \mathrm{H}, \mathrm{H}_{6^{\prime} \mathrm{a}}\right), 3.60-3.46\left(\mathrm{~m}, 2 \mathrm{H}, \mathrm{H}_{5^{\prime \prime}}\right), 3.43-3.30\left(\mathrm{~m}, 3 \mathrm{H}, \mathrm{H}_{6^{\prime} \mathrm{b}} \mathrm{H}_{2^{*}}\right)$, $2.63\left(\mathrm{~s}, 6 \mathrm{H}, \mathrm{H}_{3^{*}} \mathrm{H}_{5^{*}}\right), 1.69$ (q, J J $\left.\mathrm{H}^{\prime \prime \mathrm{a}-\mathrm{H} 8^{\prime \prime}}=7.2 \mathrm{~Hz}, 2 \mathrm{H}, \mathrm{H}_{7^{\prime \prime} \mathrm{a}}\right), 1.55$ (q, $\left.J_{\mathrm{H} 7^{\prime \prime} \mathrm{b}-\mathrm{H} 8^{\prime \prime}}=7.4 \mathrm{~Hz}, 2 \mathrm{H}, \mathrm{H}_{7^{\prime \prime} \mathrm{b}}\right), 1.38-1.12$ $(\mathrm{m}, 6 \mathrm{H}), 1.00-0.73\left(\mathrm{~m}, 24 \mathrm{H},-\mathrm{C}\left(\mathrm{CH}_{3}\right)_{3}, \mathrm{H}_{8^{\prime \prime}}\right), 0.21-0.01\left(\mathrm{~m}, 12 \mathrm{H}, \mathrm{SiCH}_{3}\right) ;{ }^{13} \mathrm{CNMR} \mathrm{N} 162.9\left(\mathrm{C}_{4}\right), 160.3$ $\left(C_{8^{*}}\right), 158.2\left(C_{8^{\prime}}\right), 150.2\left(C_{2}\right), 145.9\left(C_{10^{*}}\right), 140.6\left(C_{6}\right), 134.7\left(C_{12^{*}}\right), 124.6\left(C_{11^{*}}\right), 118.2\left(C_{6^{\prime \prime}}\right), 112.1\left(C_{1^{\prime \prime}}\right)$, $105.8\left(C_{13^{*}}\right), 101.9\left(C_{5}\right), 89.7\left(C_{1^{\prime}}\right), 86.0\left(C_{2^{\prime \prime}}\right), 85.3\left(C_{3^{\prime}}\right), 85.0\left(C_{4^{\prime \prime}}\right), 81.7\left(C_{3^{\prime \prime}}\right), 80.4\left(C_{5^{\prime}}\right), 75.0\left(C_{2^{\prime}}\right), 72.0$ $\left(C_{4^{\prime}}\right), 57.9\left(C_{5^{*}}\right), 53.8\left(C_{5^{\prime \prime}}\right), 52.7\left(C_{3^{*}}\right), 44.4\left(C_{6^{*}}\right), 42.5\left(C_{6^{\prime}}\right), 37.0\left(C_{2^{*}}\right)$ 34.3, $29.3\left(C_{7^{\prime \prime}}\right), 29.0\left(C_{7^{\prime \prime}}\right), 25.9$, $25.8,22.4,18.1,18.1,14.1,8.4,7.6,-4.0,-4.4,-4.6,-4.6$; HRMS (TOF MS ES ${ }^{+}$) calcd for $\mathrm{C}_{45} \mathrm{H}_{73} \mathrm{~F}_{3} \mathrm{~N}_{10} \mathrm{O}_{10} \mathrm{Si}_{2}{ }^{+}$ $(\mathrm{M}+\mathrm{H})^{+} 1027.5075$, found 1027.5083 .

Urea 23j. The reaction was carried out according to the general procedure for the synthesis of urea with compound 13j (18 mg, $50 \mathrm{mmol}, 1.2$ equiv.), triethylamine ( $23 \mathrm{ml}, 206 \mathrm{mmol}, 3.0$ equiv.) and carbonyldiimidazole ( $8 \mathrm{mg}, 50 \mathrm{mmol}, 1.2$ equiv.) with the amine 11 (30 mg, $41 \mathrm{mmol}, 1$ equiv.). Flash chromatography of the residue (Cyclohexane/EtOAc $=4 / 6$ ) afforded the urea $\mathbf{2 3} \mathbf{j}$ as a yellow oil (46 mg, 47\% yield): $R_{f} 0.30$ (Cyclohexane/EtOAc = 6/4); $[\alpha]_{D}-15$ (c 1.0, MeOH); IR (film) 3302, 2936, 2857, $2105,1700,1526,1462,1378,1260,1166,1098,1006,925,866,838,777,748,706 ;{ }^{1} \mathrm{H}$ NMR $\delta 7.78$ $\left(\mathrm{d}, J_{\mathrm{H} 6-\mathrm{H} 5}=8.2 \mathrm{~Hz}, 1 \mathrm{H}, \mathrm{H}_{6}\right), 7.39\left(\mathrm{~d}, J_{\mathrm{H} 13^{*}-\mathrm{H} 14^{*}}=8.1 \mathrm{~Hz}, 4 \mathrm{H}, \mathrm{H}_{13^{*}}\right), 7.24\left(\mathrm{~d}, J_{\mathrm{H}_{1} 4^{*}-\mathrm{H} 13^{*}}=8.1 \mathrm{~Hz}, 4 \mathrm{H}, \mathrm{H}_{14^{*}}\right), 7.18$ $-7.13\left(\mathrm{~m}, 2 \mathrm{H}, \mathrm{H}_{15^{*}}\right), 5.82\left(\mathrm{~d}, J_{\mathrm{H} 1^{\prime}-\mathrm{H} 2^{\prime}}=4.7 \mathrm{~Hz}, 1 \mathrm{H}, \mathrm{H}_{1^{\prime}}\right), 5.70\left(\mathrm{~d}, J_{\mathrm{H} 5-\mathrm{H} 6}=8.1 \mathrm{~Hz}, 1 \mathrm{H}, \mathrm{H}_{5}\right), 5.32-5.27(\mathrm{~m}, 1$ $\left.\mathrm{H}, \mathrm{H}_{12^{*}}\right) 5.20\left(\mathrm{~s}, 1 \mathrm{H}, \mathrm{H}_{1^{\prime \prime}}\right), 4.61\left(\mathrm{dd}, J_{\mathrm{H}^{\prime \prime}-\mathrm{H} 2^{\prime \prime}}=6.3,1.5 \mathrm{~Hz}, 1 \mathrm{H}, \mathrm{H}_{3^{\prime \prime}}\right), 4.53\left(\mathrm{~d}, J_{\mathrm{H} 2^{\prime \prime}-\mathrm{H} 3^{\prime \prime}}=6.3 \mathrm{~Hz}, 1 \mathrm{H}, \mathrm{H}_{2^{\prime \prime}}\right), 4.38$ - $4.35\left(\mathrm{~m}, 1 \mathrm{H}, \mathrm{H}_{4^{\prime \prime}}\right), 4.23-4.17\left(\mathrm{~m}, 2 \mathrm{H}, \mathrm{H}_{2^{\prime}} \mathrm{H}_{4^{\prime}}\right), 4.00\left(\mathrm{t}, J_{\mathrm{H}^{\prime}-\mathrm{H} 2^{\prime}}=4.2 \mathrm{~Hz}, 1 \mathrm{H}, \mathrm{H}_{3^{\prime}}\right), 3.87-3.81(\mathrm{~m}, 1 \mathrm{H}$, $\left.\mathrm{H}_{5^{\prime}}\right), 3.65-3.57\left(\mathrm{~m}, 1 \mathrm{H}, \mathrm{H}_{6^{\prime} \mathrm{a}}\right), 3.54-3.46\left(\mathrm{~m}, 2 \mathrm{H}, \mathrm{H}_{5^{\prime \prime}}\right), 3.38\left(\mathrm{~m}, 1 \mathrm{H}, \mathrm{H}_{6^{\prime} \mathrm{b}}\right), 3.09\left(\mathrm{dt}, J_{\mathrm{H}^{*}-\mathrm{H} 3^{*}}=5.8, J_{\mathrm{H}^{*}-}\right.$

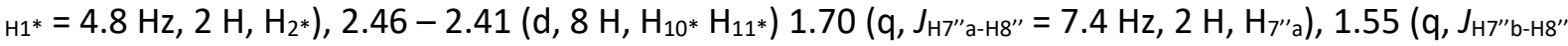
$\left.=7,4 \mathrm{~Hz}, 2 \mathrm{H}, \mathrm{H}_{7^{\prime \prime}}\right), 1.46\left(\mathrm{~m}, 2 \mathrm{H}, \mathrm{H}_{3^{*}}\right), 1.39-1.22\left(\mathrm{~m}, 18 \mathrm{H}, \mathrm{H}_{8^{\prime \prime}} \mathrm{H}_{4^{*}} \mathrm{H}_{9^{*}}\right), 0.94-0.79\left(\mathrm{~m}, 18 \mathrm{H},-\mathrm{C}\left(\mathrm{CH}_{3}\right)_{3}\right)$, $0.19-0.01\left(\mathrm{~m}, 12 \mathrm{H}, \mathrm{SiCH}_{3}\right) ;{ }^{13} \mathrm{C}$ NMR $\delta 163.24\left(\mathrm{C}_{4}\right), 158.3\left(\mathrm{C}_{8^{\prime}}\right), 150.4\left(\mathrm{C}_{2}\right), 142.80\left(\mathrm{C}_{13^{*}}\right), 140.2\left(\mathrm{C}_{6}\right)$, $128.6\left(C_{15^{*}}\right), 128.0\left(C_{14^{*}}\right), 127.0\left(C_{16^{*}}\right), 118.1\left(C_{6^{\prime \prime}}\right), 112.0\left(C_{1^{\prime \prime}}\right), 102.1\left(C_{5}\right), 89.2\left(C_{1^{\prime}}\right), 86.0\left(C_{2^{\prime \prime}}\right), 85.4\left(C_{3^{\prime}}\right)$, $85.0\left(C_{4^{\prime \prime}}\right), 81.7\left(C_{3^{\prime \prime}}\right), 80.24\left(C_{12^{*}}\right), 75.1\left(C_{2^{\prime}}\right), 72.1\left(C_{4^{\prime}}\right), 60.5\left(C_{9^{*}}\right), 53.7\left(C_{5^{\prime \prime}}\right), 53.3\left(C_{10^{*}}\right), 51.5\left(C_{11^{*}}\right), 44.23$, $42.8\left(C_{6^{\prime}}\right), 40.7\left(C_{2^{*}}\right), 34.22,30.2\left(C_{3^{*}}\right), 29.32,29.27,29.2\left(C_{7^{\prime \prime}}\right), 29.0\left(C_{7^{\prime \prime}}\right), 26.8,25.9,25.9,22.4,21.1$, $18.1,14.3,14.1,14.1,8.4,7.6,-4.0,-4.4,-4.6$; $\mathrm{HRMS} \mathrm{APCl}^{+}$calcd for $\mathrm{C}_{58} \mathrm{H}_{94} \mathrm{~N}_{9} \mathrm{O}_{10} \mathrm{Si}_{2}{ }^{+}(\mathrm{M}+\mathrm{H})^{+} 1132.6657$, found 1132.66748 .

Urea 23k. The reaction was carried out according to the general procedure for the synthesis of urea with compound 13k ( $14 \mathrm{mg}, 50 \mu \mathrm{mol}, 1.2$ equiv.), triethylamine ( $23 \mu \mathrm{L}, 165 \mu \mathrm{mol}, 4.0$ equiv.) and carbonyldiimidazole ( $8 \mathrm{mg}, 50 \mu \mathrm{mol}, 1.2$ equiv.) with the amine 11 ( $30 \mathrm{mg}, 41 \mathrm{mmol}, 1$ equiv.). Flash chromatography of the residue (Cyclohexane/EtOAc $=6 / 4$ ) afforded the urea $\mathbf{2 3 k}$ as a colorless oil (24 $\mathrm{mg}, 57 \%$ yield): $\mathrm{R}_{f} 0.45$ (Cyclohexane/EtOAc = 5/5); [ $\left.\alpha\right]_{\mathrm{D}}-7$ (c 1.0, $\mathrm{CH}_{2} \mathrm{Cl}_{2}$ ); IR (film) 3218, 2929, 2857, 2106, 1692, 1463, 1378, 1328, 1275, 1260, 1167, 1139, 1101, 926, 865, 764, 750; ${ }^{1} \mathrm{H}$ NMR $\delta 7.82$ (d, $\left.J_{\mathrm{H} 6-\mathrm{H} 5}=8.2 \mathrm{~Hz}, 1 \mathrm{H}, \mathrm{H}_{6}\right), 5.80\left(\mathrm{~d}, J_{\mathrm{H}^{\prime}-\mathrm{H} 2^{\prime}}=4.6 \mathrm{~Hz}, 1 \mathrm{H}, \mathrm{H}_{1^{\prime}}\right), 5.71\left(\mathrm{~d}, J_{\mathrm{H} 6-\mathrm{H} 5}=8.2 \mathrm{~Hz}, 1 \mathrm{H}, \mathrm{H}_{5}\right), 5.21(\mathrm{~s}, 1 \mathrm{H}$, $\left.\mathrm{H}_{1^{\prime \prime}}\right), 4.62\left(\mathrm{~d}, J_{\mathrm{H} 3^{\prime \prime}-\mathrm{H} 2^{\prime \prime}}=6.3 \mathrm{~Hz}, 1 \mathrm{H}, \mathrm{H}_{3^{\prime \prime}}\right), 4.53\left(\mathrm{~d}, J_{\mathrm{H}^{\prime \prime}-\mathrm{H} 3^{\prime \prime}}=6.3 \mathrm{~Hz}, 1 \mathrm{H}, \mathrm{H}_{2^{\prime \prime}}\right), 4.38\left(\mathrm{t}, J_{\mathrm{H} 4^{\prime \prime}-\mathrm{H} 5^{\prime \prime}}=5.1 \mathrm{~Hz}, 1 \mathrm{H}\right.$,

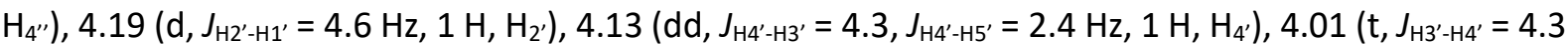
$\left.\mathrm{Hz}, 1 \mathrm{H}, \mathrm{H}_{3^{\prime}}\right), 3.88-3.83\left(\mathrm{~m}, 1 \mathrm{H}, \mathrm{H}_{5^{\prime}}\right), 3.60-3.46\left(\mathrm{~m}, 3 \mathrm{H}, \mathrm{H}_{5^{\prime \prime}} \mathrm{H}_{6^{\prime} \mathrm{a}}\right), 3.41$ (ddd, $J_{H 6^{\prime} \mathrm{b}-\mathrm{H} 6^{\prime} \mathrm{a}}=14.1, J_{H 6^{\prime} \mathrm{b}-\mathrm{H} 5^{\prime}}=$ $\left.6.8, J_{\mathrm{H}^{\prime} \mathrm{b}-\mathrm{H} 7^{\prime}}=4.2 \mathrm{~Hz}, 1 \mathrm{H}, \mathrm{H}_{6^{\prime} \mathrm{b}}\right), 3.25\left(\mathrm{~s}, 2 \mathrm{H}, \mathrm{H}_{2^{*}}\right), 1.70$ (q, $\left.J_{\mathrm{H}^{\prime \prime} \mathrm{a}-\mathrm{H} 8^{\prime \prime}}=7.2 \mathrm{~Hz}, 2 \mathrm{H}, \mathrm{H}_{7^{\prime \prime} \mathrm{a}}\right), 1.56$ (q, $J_{\mathrm{H} 7^{\prime \prime} \mathrm{b}-\mathrm{H} 8^{\prime \prime}}=$ $\left.7.4 \mathrm{~Hz}, 2 \mathrm{H}, \mathrm{H}_{7^{\prime \prime} \mathrm{b}}\right), 1.43(\mathrm{~d}, J=11.1 \mathrm{~Hz}, 4 \mathrm{H}), 1.34-1.19(\mathrm{~m}, 25 \mathrm{H}), 0.96-0.78(\mathrm{~m}, 42 \mathrm{H}), 0.20-0.00(\mathrm{~m}$, $17 \mathrm{H}) ;{ }^{13} \mathrm{C}$ NMR $\delta 162.6\left(\mathrm{C}_{4}\right), 158.3\left(\mathrm{C}_{8^{\prime}}\right), 150.0\left(\mathrm{C}_{2}\right), 140.5\left(\mathrm{C}_{6}\right), 118.0\left(\mathrm{C}_{6^{\prime \prime}}\right), 111.8\left(\mathrm{C}_{1^{\prime \prime}}\right), 101.9\left(\mathrm{C}_{5}\right), 89.0$ $\left(C_{1^{\prime}}\right), 85.9\left(C_{2^{\prime \prime}}\right), 85.6\left(C_{3^{\prime}}\right), 84.9\left(C_{4^{\prime \prime}}\right), 81.7\left(C_{3^{\prime \prime}}\right), 80.2\left(C_{5^{\prime}}\right), 75.2\left(C_{2^{\prime}}\right), 72.1\left(C_{4^{\prime}}\right), 60.5\left(C_{2^{*}}\right), 53.6\left(C_{5^{\prime \prime}}\right)$, 53.5, 53.4, 50.8, $42.3\left(C_{6^{\prime}}\right), 31.6,30.9,29.1\left(C_{7^{\prime \prime} \mathrm{a}}\right), 29.0\left(C_{7^{\prime \prime} \mathrm{b}}\right), 28.8,26.9,25.8,25.8,25.7,22.5,18.0,17.9$, 14.0, 8.3, 7.6, -4.1, -4.5, -4.7; HRMS (TOF MS ES $)$ calcd for $\mathrm{C}_{51} \mathrm{H}_{97} \mathrm{~N}_{8} \mathrm{O}_{10} \mathrm{Si}_{2}{ }^{+}(\mathrm{M}+\mathrm{H})^{+}$1037.6861, found 1037.68747 . 
General procedure for urea deprotection: To a solution of protected urea 23a-23k (1 equiv.) in dry THF was added Polymer-supported triphenylphosphine $(3 \mathrm{mmol} / \mathrm{g} ; 3$ equiv.) and pure water. The reaction mixture was carefully stirred at r.t. for $48 \mathrm{~h}$. The reaction was then filtered through a celite pad, carefully rinsed with THF and concentrated in vacuo to afford the crude amine. To the crude residue was added pure $\mathrm{H}_{2} \mathrm{O}$ and the resulting suspension was stirred at $0{ }^{\circ} \mathrm{C}$. At $0{ }^{\circ} \mathrm{C}$, TFA (300 equiv.) was added dropwise. The orange resulting solution was stirred at $0{ }^{\circ} \mathrm{C}$ for $10 \mathrm{~min}$ and then at r.t. for $18 \mathrm{~h}$. After concentration in vacuo, flash chromatography of the residue (DCM/MeOH/NH$/ \mathrm{NH}_{4} \mathrm{OH} \%$ $80 / 18 / 2$ ) afforded the fully deprotected compounds (24a-24k) in 42 to $76 \%$ yield over two steps.

Reference compound 12. Deprotected compound 12, was prepared according to the general procedure for urea deprotection from compound $\mathbf{1 1}$ (65 mg, $89.4 \mu \mathrm{mol}, 1$ equiv.), purified with C18 silica column ( $\left.\mathrm{ACN} / \mathrm{H}_{2} \mathrm{O} 6 / 4\right)$ and lyophilized to afford pure compound $\mathbf{1 2}$ as a white powder $(5.6 \mathrm{mg}$, $15 \%$ yield): $[\alpha]_{D}+6$ (c 1.0, $\left.\mathrm{H}_{2} \mathrm{O}\right)$; IR (film): 3750, 3609, 3363, 2316, 1689, 1394, 1099; ${ }^{1} \mathrm{H}$ NMR $(500 \mathrm{MHz}$, $\left.\mathrm{D}_{2} \mathrm{O}\right) \delta 7.75\left(\mathrm{~d}, 1 \mathrm{H}, J_{\mathrm{HG}-\mathrm{H} 5}=8.0 \mathrm{~Hz}, \mathrm{H}_{6}\right), 5.82\left(\mathrm{~d}, 1 \mathrm{H}, J_{H 5-H 6}=8.0 \mathrm{~Hz}, \mathrm{H}_{5}\right), 5.80\left(\mathrm{~d}, 1 \mathrm{H}, J_{\mathrm{H}^{\prime}-\mathrm{H} 2^{\prime}}=2.8 \mathrm{~Hz}, \mathrm{H}_{1^{\prime}}\right), 5.12$ $\left(\mathrm{s}, 1 \mathrm{H}, \mathrm{H}_{1^{\prime \prime}}\right), 4.29\left(\mathrm{dd}, 1 \mathrm{H}, J_{H 3^{\prime \prime}-H 4^{\prime \prime}}=5.2, J_{H 3^{\prime \prime}-H 2^{\prime \prime}}=3.0 \mathrm{~Hz}, \mathrm{H}_{3^{\prime \prime}}\right), 4.27-4.22\left(\mathrm{~m}, 1 \mathrm{H}, \mathrm{H}_{2^{\prime \prime}}\right), 4.16\left(\mathrm{dd}, 1 \mathrm{H}, \mathrm{J}_{H 4^{\prime \prime}-H 5^{\prime \prime}}=\right.$ $\left.6.8, J_{H 4^{\prime \prime}-H 3^{\prime \prime}}=5.2 \mathrm{~Hz}, \mathrm{H}_{4^{\prime \prime}}\right), 4.14-4.09\left(\mathrm{~m}, 2 \mathrm{H}, \mathrm{H}_{2^{\prime}}, \mathrm{H}_{4^{\prime}}\right), 4.08-4.01\left(\mathrm{~m}, 2 \mathrm{H}, \mathrm{H}_{3^{\prime}}, \mathrm{H}_{5^{\prime}}\right), 3.17-3.08\left(\mathrm{~m}, 2 \mathrm{H}, \mathrm{H}_{5^{\prime \prime}}\right), 3.06$ $\left(\mathrm{dd}, 1 \mathrm{H}, J_{H 6^{\prime} a-H 6^{\prime} b}=13.6, J_{H 6^{\prime} a-H 5^{\prime}}=3.9 \mathrm{~Hz}, \mathrm{H}_{6^{\prime} \mathrm{a}}\right), 2.91\left(\mathrm{dd}, 1 \mathrm{H}, J_{H 6^{\prime} b-H 6^{\prime} a}=13.6, J_{H 6^{\prime} b-H 5^{\prime}}=3.9 \mathrm{~Hz}, 1 \mathrm{H}, \mathrm{H}_{6^{\prime} b}\right) ;{ }^{13} \mathrm{C} \mathrm{NMR}$ $\left(125 \mathrm{MHz}, \mathrm{D}_{2} \mathrm{O}\right) \delta 160.4\left(\mathrm{C}_{4}\right), 152,2\left(\mathrm{C}_{2}\right), 141.1\left(\mathrm{C}_{6}\right), 108.6\left(\mathrm{C}_{1^{\prime \prime}}\right), 101.8\left(\mathrm{C}_{5}\right), 90.4\left(\mathrm{C}_{1^{\prime}}\right), 83.4\left(\mathrm{C}_{3^{\prime}}\right), 81.5\left(\mathrm{C}_{4^{\prime \prime}}\right), 77.4$ $\left(C_{5^{\prime}}\right), 75.0\left(C_{3^{\prime \prime}}\right), 74.7\left(C_{2^{\prime}}\right), 73.7\left(C_{2^{\prime}}\right), 72.1\left(C_{2^{\prime \prime}}\right), 70.8\left(C_{4^{\prime}}\right), 41.9\left(C_{5^{\prime \prime}}\right), 41.6\left(C_{6^{\prime}}\right)$; HRMS (TOF MS ES $\left.{ }^{+}\right)$calcd for $\mathrm{C}_{15} \mathrm{H}_{25} \mathrm{~N}_{4} \mathrm{O}_{9}(\mathrm{M}+\mathrm{H})^{+}$404.1616, found 405.16093.

Urea 24a was prepared according to the general procedure for urea deprotection from urea 23a (23 $\mathrm{mg}, 24.88 \mu \mathrm{mol}, 1$ equiv.) and was obtained as a white powder ( $6 \mathrm{mg}, 42 \%$ yield over two steps): $\mathrm{R}_{f}$ 0.15 (DCM/MeOH/NH$H_{4} \mathrm{OH}$ 14\% 80/18/2); $[\alpha]_{\mathrm{D}}+12$ (c 1.0, $\mathrm{CH}_{2} \mathrm{Cl}_{2}$ ); IR (film): 2924, 2852, 1782, 1646, 1275, 1260, 1004, 764, 75.; ${ }^{1} \mathrm{H}$ NMR $(500 \mathrm{MHz}, \mathrm{MeOD}) \delta 7.86$ (d, $\left.J_{\mathrm{H} 6-\mathrm{H} 5}=8.1 \mathrm{~Hz}, 1 \mathrm{H}, \mathrm{H}_{6}\right), 5.82\left(\mathrm{~d}, J_{\mathrm{H}^{\prime}{ }^{\prime} \mathrm{Hz}^{\prime}}\right.$ $\left.=2.7 \mathrm{~Hz}, 1 \mathrm{H}, \mathrm{H}_{1^{\prime}}\right), 5.71\left(\mathrm{~d}, J_{\mathrm{H} 5-\mathrm{H} 6}=8.1 \mathrm{~Hz}, 1 \mathrm{H}, \mathrm{H}_{5}\right), 5.11\left(\mathrm{~s}, 1 \mathrm{H}, \mathrm{H}_{1^{\prime \prime}}\right), 4.15-4.13\left(\mathrm{~m}, 1 \mathrm{H}, \mathrm{H}_{2^{\prime}}\right), 4.12-4.05$ $\left(\mathrm{m}, 3 \mathrm{H}, \mathrm{H}_{3^{\prime}}, \mathrm{H}_{4^{\prime}}, \mathrm{H}_{4^{\prime \prime}}\right), 4.05-4.01\left(\mathrm{~m}, 1 \mathrm{H}, \mathrm{H}_{2^{\prime \prime}}\right), 3.97\left(\mathrm{~d}, J_{\mathrm{H} 3^{\prime \prime}-\mathrm{H} 2^{\prime \prime}}=4.2 \mathrm{~Hz}, 1 \mathrm{H}, \mathrm{H}_{3^{\prime \prime}}\right), 3.93-3.88(\mathrm{t}, J=5.7$

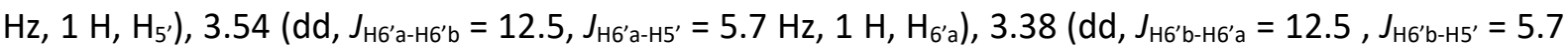
$\left.\mathrm{Hz} 1 \mathrm{H}, \mathrm{H}_{6^{\prime}}\right), 3.26\left(\mathrm{~d}, J_{\mathrm{H} 5^{\prime \prime}-\mathrm{H} 4^{\prime \prime}}=13.5 \mathrm{~Hz}, 1 \mathrm{H}, \mathrm{H}_{5^{\prime \prime}} \mathrm{a}\right), 3.11\left(\mathrm{t}, J_{\mathrm{H} 2^{*}-\mathrm{H} 3^{*}}=7.0 \mathrm{~Hz}, 2 \mathrm{H}, \mathrm{H}_{2^{*}}\right), 3.06-2.99(\mathrm{~m}, 1 \mathrm{H}$,

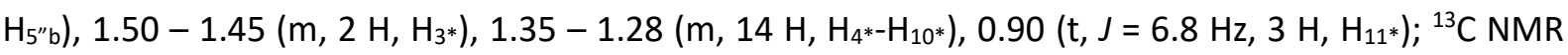
(125 MHz, MeOD) $\delta 166.1\left(C_{4}\right), 161.2\left(C_{8^{\prime}}\right), 152.2\left(C_{2}\right), 142.1\left(C_{6}\right), 110.7\left(C_{1^{\prime \prime}}\right), 102.4\left(C_{5}\right), 91.5\left(C_{1^{\prime}}\right), 84.7$ $\left(C_{3^{\prime}}\right), 80.8\left(C_{4^{\prime \prime}}\right), 78.2\left(C_{5^{\prime}}\right), 76.3\left(C_{3^{\prime \prime}}\right), 75.7\left(C_{2^{\prime}}\right), 74.0\left(C_{2^{\prime \prime}}\right), 71.0\left(C_{4^{\prime}}\right), 44.9\left(C_{5^{\prime \prime}}\right), 42.9\left(C_{6^{\prime}}\right), 41.2\left(C_{2^{*}}\right), 33.1$ $\left(C_{3^{*}}\right), 31.3,30.7,30.7,30.5,30.4,28.0,23.71\left(C_{4^{*}-} C_{10^{*}}\right), 14.4\left(C_{11^{*}}\right)$; HRMS (TOF MS ES $)$ calcd for $\mathrm{C}_{26} \mathrm{H}_{45} \mathrm{~N}_{5} \mathrm{O}_{10}(\mathrm{M}+\mathrm{H})^{+} 588.3239$, found 588.3233 .

Urea 24b was prepared according to the general procedure for urea deprotection from urea $\mathbf{2 3 b}$ (15 $\mathrm{mg}, 16.44 \mu \mathrm{mol}, 1$ equiv.) and was obtained as a white powder (6.5 mg, $63 \%$ yield over two steps): $\mathrm{R}_{f}$

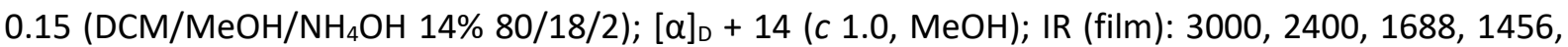
$1275,1260,1203,764,750 ;{ }^{1} \mathrm{H}$ NMR $(500 \mathrm{MHz}, \mathrm{MeOD}) \delta 7.75\left(\mathrm{~d}, J_{\mathrm{HG}-\mathrm{H} 5}=8.1 \mathrm{~Hz}, 1 \mathrm{H}, \mathrm{H}_{6}\right), 5.71\left(\mathrm{~d}, J_{\mathrm{H}^{\prime}-}\right.$ $\left.\mathrm{H}^{\prime}=2.8 \mathrm{~Hz}, 1 \mathrm{H}, \mathrm{H}_{1^{\prime}}\right), 5.61\left(\mathrm{~d}, \mathrm{~J}_{\mathrm{H} 6-\mathrm{H} 5}=8.1 \mathrm{~Hz}, 1 \mathrm{H}, \mathrm{H}_{5}\right), 5.02\left(\mathrm{~s}, 1 \mathrm{H}, \mathrm{H}_{1^{\prime \prime}}\right), 4.06-4.03\left(\mathrm{~m}, 1 \mathrm{H}, \mathrm{H}_{2^{\prime}}\right), 4.02-$ $3.97\left(\mathrm{~m}, 3 \mathrm{H}, \mathrm{H}_{3^{\prime}}, \mathrm{H}_{4^{\prime}}, \mathrm{H}_{4^{\prime \prime}}\right), 3.95\left(\mathrm{~d}, J_{\mathrm{H} 2^{\prime \prime}-\mathrm{H} 3^{\prime \prime}}=4.4 \mathrm{~Hz}, 1 \mathrm{H}, \mathrm{H}_{2^{\prime \prime}}\right), 3.88\left(\mathrm{~d}, J_{\mathrm{H}^{\prime \prime}-\mathrm{H} 2^{\prime \prime}}=4.4 \mathrm{~Hz}, 1 \mathrm{H}, \mathrm{H}_{3^{\prime \prime}}\right), 3.83-$ $3.79\left(\mathrm{~m}, 1 \mathrm{H}, \mathrm{H}_{5^{\prime}}\right), 3.56\left(\mathrm{dd}, J_{\mathrm{H}^{\prime} \mathrm{a}-\mathrm{H} 6^{\prime} \mathrm{b}}=9.6, J_{\mathrm{H} 6^{\prime} \mathrm{a}-\mathrm{H} 5}=3.4 \mathrm{~Hz}, 1 \mathrm{H}, \mathrm{H}_{6^{\prime} \mathrm{a}}\right), 3.45$ (dd, $J_{\mathrm{H} 6^{\prime} \mathrm{b}-\mathrm{H} 5^{\prime}}=9.6,4.9 \mathrm{~Hz}, 1 \mathrm{H}$, $\left.\mathrm{H}_{6^{\prime} \mathrm{b}}\right), 3.26\left(\mathrm{dd}, J_{\mathrm{H} 5^{\prime \prime} \mathrm{a}-\mathrm{H} 5^{\prime \prime} \mathrm{b}}=15.0, J_{\mathrm{H} 5^{\prime \prime} \mathrm{a}-\mathrm{H} 4^{\prime}}=6.6 \mathrm{~Hz}, 1 \mathrm{H}, \mathrm{H}_{5^{\prime \prime}} \mathrm{a}\right), 3.05-2.94\left(\mathrm{~m}, 3 \mathrm{H}, \mathrm{H}_{5^{\prime \prime}}, \mathrm{H}_{2^{*}}\right), 1.37\left(\mathrm{dt}, J_{\mathrm{H}^{*}-}\right.$ $\left.\mathrm{H}^{*}=10.9, \mathrm{~J}_{3^{*}-\mathrm{H} 4^{*}}=4.3 \mathrm{~Hz}, 2 \mathrm{H}, \mathrm{H}_{3^{*}}\right), 1.3-1.1\left(\mathrm{~m}, 18 \mathrm{H}, \mathrm{H}_{4^{*}}-\mathrm{H}_{12^{*}}\right), 0.80\left(\mathrm{t}, J_{\mathrm{H}_{13} 3^{*} \mathrm{H} 12^{*}}=6.8 \mathrm{~Hz}, 3 \mathrm{H}, \mathrm{H}_{13^{*}}\right) ;{ }^{13} \mathrm{C}$ NMR (125 MHz, MeOD) $\delta 166.1\left(C_{4}\right), 161.2\left(C_{8^{\prime}}\right), 152.2\left(C_{2}\right), 142.1\left(C_{6}\right), 110.8\left(C_{1^{\prime \prime}}\right), 102.4\left(C_{5}\right), 91.6\left(C_{1^{\prime}}\right)$, $84.7\left(C_{3^{\prime}}\right), 80.0\left(C_{4^{\prime \prime}}\right), 78.0\left(C_{5^{\prime}}\right), 76.2\left(C_{3^{\prime \prime}}\right), 75.7\left(C_{2^{\prime}}\right), 74.1\left(C_{2^{\prime \prime}}\right), 70.9\left(C_{4^{\prime}}\right), 44.7\left(C_{5^{\prime \prime}}\right), 42.8\left(C_{6^{\prime}}\right), 41.2\left(C_{2^{*}}\right)$, $33.1\left(C_{3^{*}}\right), 31.32,30.8,30.7,30.5,30.5,30.4,28.0,26.3,23.7\left(C_{4^{*}}-C_{12^{*}}\right), 14.4\left(C_{13^{*}}\right)$; HRMS (TOF MS ES $\left.{ }^{+}\right)$ calcd for $\mathrm{C}_{28} \mathrm{H}_{50} \mathrm{~N}_{5} \mathrm{O}_{10}(\mathrm{M}+\mathrm{H})^{+} 616.3352$, found 616.3562 . 
Urea $\mathbf{2 4 c}$ was prepared according to the general procedure for urea deprotection from urea $\mathbf{2 3 c}$ (20 $\mathrm{mg}, 20.82 \mu \mathrm{mol}, 1$ equiv.) and was obtained as a white powder ( $9 \mathrm{mg}, 63 \%$ yield over two steps): $\mathrm{R}_{f}$ 0.12 (DCM/MeOH/ $\mathrm{NH}_{4} \mathrm{OH}$ 14\% 80/18/2); $[\alpha]_{\mathrm{D}}+9$ (c 1.0, $\mathrm{CH}_{2} \mathrm{Cl}_{2}$ ); IR (film): 3443, 2922, 1734, 1437, $1278,1260,1028,954,764,750 ;{ }^{1} \mathrm{H}$ NMR $(500 \mathrm{MHz}, \mathrm{MeOD}) \delta 7.84\left(\mathrm{~d}, J_{\mathrm{H} 6-\mathrm{H} 5}=8.2 \mathrm{~Hz}, 1 \mathrm{H}, \mathrm{H}_{6}\right), 7.27-$ $7.21\left(\mathrm{~m}, 2 \mathrm{H}, \mathrm{H}_{14^{*}}\right), 7.15\left(\mathrm{~d}, J_{\mathrm{H} 13^{*}-\mathrm{H} 14^{*}}=7.3 \mathrm{~Hz}, 2 \mathrm{H}, \mathrm{H}_{13^{*}}\right), 7.12\left(\mathrm{~d}, J_{\mathrm{H} 15^{*}-\mathrm{H} 14^{*}}=7.1 \mathrm{~Hz}, 1 \mathrm{H}, \mathrm{H}_{15^{*}}\right), 5.81$ (d, $\left.J_{\mathrm{H}^{\prime}-\mathrm{H} 2^{\prime}}=2.8 \mathrm{~Hz}, 1 \mathrm{H}, \mathrm{H}_{1^{\prime}}\right), 5.70\left(\mathrm{~d}, J_{\mathrm{H} 5-\mathrm{H} 6}=8.2 \mathrm{~Hz}, 1 \mathrm{H}, \mathrm{H}_{5}\right), 5.12\left(\mathrm{~s}, 1 \mathrm{H}, \mathrm{H}_{1^{\prime \prime}}\right), 4.17-4.12\left(\mathrm{~m}, 1 \mathrm{H}, \mathrm{H}_{2^{\prime}}\right), 4.12$ $-4.06\left(\mathrm{~m}, 3 \mathrm{H}, \mathrm{H}_{3^{\prime}}, \mathrm{H}_{4^{\prime}}, \mathrm{H}_{4^{\prime \prime}}\right), 4.04\left(\mathrm{~d}, \mathrm{~J}_{\mathrm{H}^{\prime \prime}-\mathrm{H} 3^{\prime \prime}}=4.4 \mathrm{~Hz}, 1 \mathrm{H}, \mathrm{H}_{2^{\prime \prime}}\right), 3.97\left(\mathrm{~d}, \mathrm{~J}_{\mathrm{H}^{\prime \prime}-\mathrm{H} 2^{\prime \prime}}=4.4 \mathrm{~Hz}, 1 \mathrm{H}, \mathrm{H}_{3^{\prime \prime}}\right), 3.90(\mathrm{~m}$, $\left.1 \mathrm{H}, \mathrm{H}_{5^{\prime}}\right), 3.56\left(\mathrm{~d}, J_{\mathrm{H} 6^{\prime} \mathrm{a}-\mathrm{H} 5^{\prime}}=4.8 \mathrm{~Hz}, 1 \mathrm{H}, \mathrm{H}_{6^{\prime} \mathrm{a}}\right), 3.53\left(\mathrm{~d}, J_{\mathrm{H} 6^{\prime} \mathrm{b}-\mathrm{H} 5^{\prime}}=4.8 \mathrm{~Hz}, 1 \mathrm{H}, \mathrm{H}_{6^{\prime} \mathrm{b}}\right), 3.37\left(\mathrm{~d}, J_{\mathrm{H} 5^{\prime \prime} \mathrm{a}-\mathrm{H} 4^{\prime \prime}}=7.7 \mathrm{~Hz}\right.$, $\left.1 \mathrm{H}, \mathrm{H}_{5^{\prime \prime}} \mathrm{a}\right), 3.13\left(\mathrm{t}, J_{\mathrm{H}^{*}-\mathrm{H} 3^{*}}=7.0 \mathrm{~Hz}, 2 \mathrm{H}, \mathrm{H}_{2^{*}}\right), 3.08-3.03\left(\mathrm{~m}, 1 \mathrm{H}, \mathrm{H}_{5^{\prime \prime}} \mathrm{b}\right), 2.59\left(\mathrm{t}, J_{\mathrm{H} 11^{*}-\mathrm{H} 10^{*}}=7.6 \mathrm{~Hz}, 2 \mathrm{H}\right.$, $\left.\mathrm{H}_{11^{*}}\right), 1.61\left(\mathrm{t}, J_{\mathrm{H} 10^{*}-\mathrm{H} 11^{*}}=J_{\mathrm{H} 10^{*}-\mathrm{H} 9^{*}}=7.6 \mathrm{~Hz}, 2 \mathrm{H}, \mathrm{H}_{10^{*}}\right), 1.50-1.43\left(\mathrm{~m}, 1 \mathrm{H}, \mathrm{H}_{3^{*}}\right), 1.38-1.22\left(\mathrm{~m}, 12 \mathrm{H}, \mathrm{H}_{4^{*}}\right.$ $\left.9^{*}\right) ;{ }^{13} \mathrm{C}$ NMR (125 MHz, MeOD) $\delta 166.1\left(C_{4}\right), 161.2\left(C_{8^{\prime}}\right), 152.2\left(C_{2}\right), 144.0\left(C_{12^{*}}\right), 142.1\left(C_{6}\right), 129.4\left(C_{13^{*}}\right)$, $129.3\left(C_{14^{*}}\right), 126.6\left(C_{15^{*}}\right), 110.8\left(C_{1^{\prime \prime}}\right), 102.4\left(C_{5}\right), 91.7\left(C_{1^{\prime}}\right), 84.6\left(C_{3^{\prime}}\right), 80.0\left(C_{4^{\prime \prime}}\right), 78.0\left(C_{5^{\prime}}\right), 76.3\left(C_{3^{\prime \prime}}\right), 75.7$ $\left(C_{2^{\prime}}\right), 74.1\left(C_{2^{\prime \prime}}\right), 70.9\left(C_{4^{\prime}}\right), 44.7\left(C_{5^{\prime \prime}}\right), 42.9\left(C_{6^{\prime}}\right), 41.2\left(C_{2^{*}}\right), 36.9\left(C_{11^{*}}\right), 32.8\left(C_{10^{*}}\right), 31.3\left(C_{3^{*}}\right), 30.8,30.7$, 30.6, 30.5, 30.3, $28.0\left(\mathrm{C}_{4^{*}-} \mathrm{C}_{9^{*}}\right)$; $\mathrm{HRMS} \mathrm{APCl}{ }^{+}$calcd for $\mathrm{C}_{32} \mathrm{H}_{50} \mathrm{~N}_{5} \mathrm{O}_{10}(\mathrm{M}+\mathrm{H})^{+} 664.3552$, found 664.3552 .

Urea $\mathbf{2 4 d}$ was prepared according to the general procedure for urea deprotection from urea $\mathbf{2 3 d} \mathbf{d} \mathbf{2 8}$ $\mathrm{mg}, 26.6 \mu \mathrm{mol}, 1$ equiv.) and was obtained as a white powder ( $15.2 \mathrm{mg}, 76 \%$ yield over two steps): $\mathrm{R}_{f}$

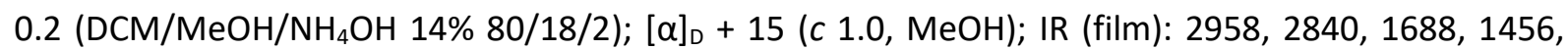
$1275,1260,1203,764,750 ;{ }^{1} \mathrm{H}$ NMR $(500 \mathrm{MHz}, \mathrm{MeOD}) \delta 7.84\left(\mathrm{~d}, J_{\mathrm{H} 6-\mathrm{H} 5}=8.1 \mathrm{~Hz}, 1 \mathrm{H}, \mathrm{H}_{6}\right), 7.79\left(\mathrm{~d}, J_{\mathrm{H}_{11} *}\right.$. \left.${\mathrm{H} 10^{*}}^{*}=8.9 \mathrm{~Hz}, 2 \mathrm{H}, \mathrm{H}_{11^{*}}\right), 7.72\left(\mathrm{~d}, J_{\mathrm{H} 15^{*}-\mathrm{H} 16^{*}}=8.3 \mathrm{~Hz}, 2 \mathrm{H}, \mathrm{H}_{15^{*}}\right), 7.62\left(\mathrm{~d}, J_{\mathrm{H} 17^{*}-\mathrm{H} 16^{*}}=10.5 \mathrm{~Hz}, 2 \mathrm{H}, \mathrm{H}_{17^{*}}\right), 7.55$ $-7.50\left(\mathrm{~m}, 2 \mathrm{H}, \mathrm{H}_{16^{*}}\right), 7.03\left(\mathrm{~d}, J_{\mathrm{H} 10^{*}-\mathrm{H} 11^{*}}=8.9 \mathrm{~Hz}, 2 \mathrm{H}, \mathrm{H}_{10^{*}}\right), 5.81\left(\mathrm{~d}, J_{\mathrm{H} 1^{\prime}-\mathrm{H} 2^{\prime}}=3.0 \mathrm{~Hz}, 1 \mathrm{H}, \mathrm{H}_{1^{\prime}}\right), 5.70\left(\mathrm{~d}, J_{\mathrm{H} 5-}\right.$ $\left.\mathrm{H} 6=8.1 \mathrm{~Hz}, 1 \mathrm{H}, \mathrm{H}_{5}\right), 5.12\left(\mathrm{~s}, 1 \mathrm{H}, \mathrm{H}_{12}\right), 4.13\left(\mathrm{~d}, \mathrm{~J}_{\mathrm{H} 1^{\prime}-\mathrm{H} 2^{\prime}}=3.0 \mathrm{~Hz}, 2 \mathrm{H}, \mathrm{H}_{2^{\prime}}\right), 4.12-4.07\left(\mathrm{~m}, 3 \mathrm{H}, \mathrm{H}_{3^{\prime}}, \mathrm{H}_{4^{\prime}}, \mathrm{H}_{4^{\prime \prime}}\right)$, $4.04\left(\mathrm{~d}, \mathrm{~J}_{\mathrm{H} 2^{\prime \prime}-\mathrm{H} 3^{\prime \prime}}=5.1 \mathrm{~Hz}, 1 \mathrm{H}, \mathrm{H}_{2^{\prime \prime}}\right), 3.97\left(\mathrm{~d}, \mathrm{~J}_{\mathrm{H}^{\prime \prime}-\mathrm{H} 2^{\prime \prime}}=5.1 \mathrm{~Hz}, 1 \mathrm{H}, \mathrm{H}_{3^{\prime \prime}}\right), 3.93-3.88\left(\mathrm{~m}, 1 \mathrm{H}, \mathrm{H}_{5^{\prime}}\right), 3.65-3.63$ $\left(\mathrm{m}, 2 \mathrm{H}, \mathrm{H}_{8^{*}}\right), 3.54\left(\mathrm{~d}, \mathrm{~J}_{\mathrm{H6^{ \prime }} \mathrm{a}-\mathrm{H} 5^{\prime}}=6.8 \mathrm{~Hz}, 1 \mathrm{H}, \mathrm{H}_{6^{\prime} \mathrm{a}}\right), 3.38\left(\mathrm{~d}, J_{\mathrm{H} 6^{\prime} \mathrm{b}-\mathrm{H} 5^{\prime}}=7.6 \mathrm{~Hz}, 1 \mathrm{H}, \mathrm{H}_{6^{\prime} \mathrm{b}}\right), 3.19-3.15(\mathrm{~m}, 1 \mathrm{H}$, $\left.\mathrm{H}_{5^{\prime \prime} \mathrm{a}}\right), 3.14-3.10\left(\mathrm{~m}, 2 \mathrm{H}, \mathrm{H}_{2^{*}}\right), 3.07$ (dd, $\left.J_{\mathrm{H} 5^{\prime \prime} \mathrm{b}-\mathrm{H} 5^{\prime \prime a}}=13.1, J_{\mathrm{H} 5^{\prime \prime} \mathrm{b}-\mathrm{H} 4^{\prime \prime}}=10.1 \mathrm{~Hz}, 1 \mathrm{H}, \mathrm{H}_{5^{\prime \prime} \mathrm{b}}\right), 1.86-1.78(\mathrm{~m}, 4$ H), $1.63-1.56(\mathrm{~m}, 4 \mathrm{H}), 1.54-1.47(\mathrm{~m}, 4 \mathrm{H}) ;{ }^{13} \mathrm{C}$ NMR (125 MHz, MeOD) $\delta 197.8\left(\mathrm{C}_{13^{*}}\right), 166.1\left(\mathrm{C}_{4}\right), 164.7$ $\left(C_{9^{*}}\right), 161.2\left(C_{8^{\prime}}\right), 152.2\left(C_{2}\right), 142.1\left(C_{6}\right), 133.7\left(C_{14^{*}}\right), 133.3\left(C_{11^{*}}\right), 131.0\left(C_{17^{*}}\right), 130.7\left(C_{12^{*}}\right), 129.4\left(C_{15^{*}}\right)$, $115.3\left(C_{16^{*}}\right), 110.8\left(C_{1^{\prime \prime}}\right), 102.4\left(C_{5}\right), 91.7\left(C_{1^{\prime}}\right), 84.6\left(C_{3^{\prime}}\right), 80.0\left(C_{4^{\prime \prime}}\right), 78.0\left(C_{5^{\prime}}\right), 76.3\left(C_{3^{\prime \prime}}\right), 75.7\left(C_{2^{\prime}}\right), 74.0$ $\left(C_{2^{\prime \prime}}\right), 70.9\left(C_{4^{\prime}}\right), 69.4\left(C_{8^{*}}\right), 57.7,44.7\left(C_{5^{\prime \prime}}\right), 33.0,31.2,30.7,30.6,30.6,30.2$; HRMS (TOF MS ES ${ }^{+}$) calcd for $\mathrm{C}_{28} \mathrm{H}_{50} \mathrm{~N}_{5} \mathrm{O}_{10}(\mathrm{M}+\mathrm{H})^{+} 756.3450$, found 756.34626 .

Urea 24e was prepared according to the general procedure for urea deprotection from urea $23 \mathbf{e}$ (20 $\mathrm{mg}, 19.04 \mu \mathrm{mol}, 1$ equiv.) and was obtained as a colourless oil $\left(8.5 \mathrm{mg}, 61 \%\right.$ yield over two steps): $\mathrm{R}_{f}$ 0.10 (DCM/MeOH/NH$/ \mathrm{NH}_{4} \mathrm{OH}$ 14\% 80/18/2); $[\alpha]_{\mathrm{D}}+6$ (c 1.0, MeOH); IR (film): 3373, 2926, 2450, 2072, 1675, 1463, 1121, 974; ${ }^{1} \mathrm{H}$ NMR (500 MHz, MeOD) $\delta 7.84$ (d, J J6-H5 $\left.=8.1 \mathrm{~Hz}, 1 \mathrm{H}, \mathrm{H}_{6}\right), 5.81$ (d, J J $\mathrm{H}^{\prime} \mathrm{H}^{\prime} \mathrm{H}^{\prime}=$ $\left.2.9 \mathrm{~Hz}, 1 \mathrm{H}, \mathrm{H}_{1^{\prime}}\right), 5.70\left(\mathrm{~d}, J_{\mathrm{H} 5-\mathrm{H} 6}=8.1 \mathrm{~Hz}, 1 \mathrm{H}, \mathrm{H}_{5}\right), 5.12\left(\mathrm{~s}, 1 \mathrm{H}, \mathrm{H}_{1^{\prime \prime}}\right), 4.16-4.07\left(\mathrm{~m}, 4 \mathrm{H}, \mathrm{H}_{2^{\prime}} \mathrm{H}_{3^{\prime}} \mathrm{H}_{4^{\prime}} \mathrm{H}_{4^{\prime \prime}}\right), 4.05$ $\left(\mathrm{d}, J_{\mathrm{H}^{\prime \prime}-\mathrm{H} 3^{\prime \prime}}=4.5 \mathrm{~Hz}, 1 \mathrm{H}, \mathrm{H}_{2^{\prime \prime}}\right), 3.98\left(\mathrm{~d}, \mathrm{~J}_{\mathrm{H}^{\prime \prime}}-\mathrm{H}^{\prime \prime}=4.5 \mathrm{~Hz}, 1 \mathrm{H}, \mathrm{H}_{3^{\prime \prime}}\right), 3.94-3.88\left(\mathrm{~m}, 1 \mathrm{H}, \mathrm{H}_{5^{\prime}}\right), 3.58-3.52(\mathrm{~m}$, $\left.1 \mathrm{H}, \mathrm{H}_{6^{\prime} \mathrm{a}}\right), 3.36\left(\mathrm{dd}, J_{\mathrm{HG}^{\prime} \mathrm{b}-\mathrm{H6^{ \prime } \mathrm { a }}}=12.8, J_{\mathrm{H6^{ \prime }} \mathrm{b}-\mathrm{H} 5^{\prime}}=3.6 \mathrm{~Hz}, 1 \mathrm{H}, \mathrm{H}_{6^{\prime} \mathrm{b}}\right), 3.33-3.27\left(\mathrm{~m}, 1 \mathrm{H}, \mathrm{H}_{5^{\prime \prime} \mathrm{a}}\right), 3.15\left(\mathrm{dt}, J_{\mathrm{H}^{*}{ }_{\mathrm{a}}-}\right.$ $\left.\mathrm{H}^{*}{ }^{*} \mathrm{~b}=16.6, J_{\mathrm{H}^{*}-\mathrm{H} 3^{*}}=8.5 \mathrm{~Hz}, 2 \mathrm{H}, \mathrm{H}_{2^{*}}\right), 3.07$ (dd, $\left.J_{\mathrm{H} 5^{\prime \prime b}-\mathrm{H} 5^{\prime \prime a}}=12.9, J_{\mathrm{H} 5^{\prime \prime b}-\mathrm{H} 4^{\prime \prime}}=10.0 \mathrm{~Hz}, 1 \mathrm{H}, \mathrm{H}_{5^{\prime \prime} \mathrm{b}}\right), 1.59-1.47$

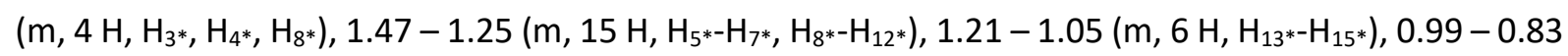
$\left(\mathrm{m}, 16 \mathrm{H}, \mathrm{H}_{16^{*}}, 5 \mathrm{CH}_{3}\right) ;{ }^{13} \mathrm{C}$ NMR $(125 \mathrm{MHz}, \mathrm{MeOD}) \delta 166.1\left(\mathrm{C}_{4}\right), 161.2\left(\mathrm{C}_{8^{\prime}}\right), 152.2\left(\mathrm{C}_{2}\right), 142.1\left(\mathrm{C}_{6}\right), 110.8$ $\left(C_{1^{\prime \prime}}\right), 102.4\left(C_{5}\right), 91.6\left(C_{1^{\prime}}\right), 84.6\left(C_{3^{\prime}}\right), 79.9\left(C_{4^{\prime \prime}}\right), 78.1\left(C_{5^{\prime}}\right), 76.2\left(C_{3^{\prime \prime}}\right) 75.7\left(C_{2^{\prime}}\right), 74.1\left(C_{2^{\prime \prime}}\right), 70.9\left(C_{4^{\prime}}\right), 44.6$ $\left(C_{5^{\prime \prime}}\right), 42.8\left(C_{6^{\prime}}\right), 40.5\left(C_{2^{*}}\right), 39.2\left(C_{3^{*}}\right), 38.6,38.5,38.5,38.4,38.4,38.3,33.9,33.9\left(C_{12^{*}}\right), 31.8\left(C_{8^{*}}\right), 30.7$, $29.1\left(\mathrm{C}_{4^{*}}\right), 25.8,25.4,23.0,23.0,20.2\left(\mathrm{CH}_{3}\right), 20.1\left(\mathrm{CH}_{3}\right), 20.1\left(\mathrm{CH}_{3}\right), 19.9\left(\mathrm{CH}_{3}\right), 19.9\left(\mathrm{CH}_{3}\right)$; HRMS (TOF MS ES ${ }^{+}$) calcd for $\mathrm{C}_{36} \mathrm{H}_{65} \mathrm{~N}_{4} \mathrm{O}_{10}(\mathrm{M}+\mathrm{H})^{+} 728.4804$, found 728.4825 .

Urea $\mathbf{2 4 f}$ was prepared according to the general procedure for urea deprotection from urea $\mathbf{2 3 f}$ (31 $\mathrm{mg}, 34.51 \mu \mathrm{mol}, 1$ equiv.) and was obtained as a white powder ( $12.5 \mathrm{mg}, 60 \%$ yield over two steps): $\mathrm{R}_{f} 0.15$ (DCM/MeOH/ $\mathrm{NH}_{4} \mathrm{OH} 14 \%$ 80/18/2); $[\alpha]_{\mathrm{D}}+13$ (c 1.0, $\mathrm{CH}_{2} \mathrm{Cl}_{2}$ ); IR (film) 3900, 3748, 2924, 1699, 
$1541,1456,1275,1260,1203,764,750 ;{ }^{1} \mathrm{H}$ NMR (500 MHz, MeOD) $\delta$ 7.86-7.80 (m, $4 \mathrm{H}, \mathrm{H}_{6^{*}}, \mathrm{H}_{8^{*}}, \mathrm{H}_{11^{*}}$, $\left.\mathrm{H}_{6}\right), 7.67\left(\mathrm{~s}, 1 \mathrm{H}, \mathrm{H}_{13^{*}}\right), 7.48-7.39\left(\mathrm{~m}, 2 \mathrm{H}, \mathrm{H}_{9^{*}}, \mathrm{H}_{10^{*}}\right), 7.37\left(\mathrm{~d}, J=8.3 \mathrm{~Hz}, 1 \mathrm{H}, \mathrm{H}_{5^{*}}\right), 5.80\left(\mathrm{~d}, \mathrm{~J}_{\mathrm{H}^{\prime}-\mathrm{H} 2^{\prime}}=2.9\right.$ $\left.\mathrm{Hz}, 1 \mathrm{H}, \mathrm{H}_{1^{\prime}}\right), 5.70\left(\mathrm{~d}, J_{\mathrm{H} 5-\mathrm{H} 6}=8.1 \mathrm{~Hz}, 1 \mathrm{H}, \mathrm{H}_{5}\right), 5.11\left(\mathrm{~s}, 1 \mathrm{H}, \mathrm{H}_{1^{\prime \prime}}\right), 4.15-4.12\left(\mathrm{~m}, 1 \mathrm{H}, \mathrm{H}_{2^{\prime}}\right), 4.12-4.06(\mathrm{~m}$, $\left.3 \mathrm{H}, \mathrm{H}_{3^{\prime}}, \mathrm{H}_{4^{\prime}}, \mathrm{H}_{4^{\prime \prime}}\right), 4.03\left(\mathrm{~d}, J_{\mathrm{H}^{\prime \prime}-\mathrm{H} 3^{\prime \prime}}=4.5 \mathrm{~Hz}, 1 \mathrm{H}, \mathrm{H}_{2^{\prime \prime}}\right), 3.97\left(\mathrm{~d}, J_{\mathrm{H}^{\prime \prime}-\mathrm{H} 2^{\prime \prime}}=4.5 \mathrm{~Hz}, 1 \mathrm{H}, \mathrm{H}_{3^{\prime \prime}}\right), 3.91-3.86(\mathrm{~m}, 1$ $\left.\mathrm{H}, \mathrm{H}_{5^{\prime}}\right), 3.53\left(\mathrm{dd}, J_{\mathrm{H} 6^{\prime} \mathrm{a}-\mathrm{H} 6^{\prime} \mathrm{b}}=14.1, J_{\mathrm{H} 6^{\prime} \mathrm{a}-\mathrm{H} 5^{\prime}}=5.0 \mathrm{~Hz}, 1 \mathrm{H}, \mathrm{H}_{6^{\prime} \mathrm{a}}\right), 3.48\left(\mathrm{td}, J_{\mathrm{H}^{*}-\mathrm{H} 3^{*}}=6.9, J_{\mathrm{H}^{*}-\mathrm{H} 7^{\prime}}=3.0 \mathrm{~Hz}, 2 \mathrm{H}\right.$, $\left.\mathrm{H}_{2^{*}}\right), 3.35\left(\mathrm{~m}, 1 \mathrm{H}, \mathrm{H}_{6^{\prime} \mathrm{b}}\right), 3.27\left(\mathrm{~d}, J_{\mathrm{H} 5^{\prime \prime} \mathrm{a}-\mathrm{H} 4^{\prime \prime}}=2.8 \mathrm{~Hz}, 1 \mathrm{H}, \mathrm{H}_{5^{\prime \prime} \mathrm{a}}\right), 3.04\left(\mathrm{~m}, 1 \mathrm{H}, \mathrm{H}_{5^{\prime \prime} \mathrm{b}}\right), 2.95\left(\mathrm{t}, J_{\mathrm{H}^{*}-\mathrm{H} 2^{*}}=6.9 \mathrm{~Hz}\right.$, $\left.2 \mathrm{H}, \mathrm{H}_{3^{*}}\right) ;{ }^{13} \mathrm{C}$ NMR (125 MHz, MeOD) $\delta 166.1\left(\mathrm{C}_{4}\right), 161.1\left(\mathrm{C}_{8^{\prime}}\right), 152.2\left(\mathrm{C}_{2}\right), 142.1\left(\mathrm{C}_{6}\right), 138.3\left(\mathrm{C}_{4^{*}}\right), 135.2$ $\left(C_{7^{*}}\right), 133.8\left(C_{12^{*}}\right), 129.1\left(C_{6^{*}}\right), 128.6\left(C_{8^{*}}\right), 128.5\left(C_{11^{*}}\right), 128.4\left(C_{5^{*}}\right), 128.2\left(C_{13^{*}}\right), 127.0\left(C_{9^{*}}\right), 126.4\left(C_{10^{*}}\right)$, $110.8\left(C_{1^{\prime \prime}}\right), 102.4\left(C_{5}\right), 91.6\left(C_{1^{\prime}}\right), 84.7\left(C_{3^{\prime}}\right), 80.1\left(C_{4^{\prime \prime}}\right), 78.1\left(C_{5^{\prime}}\right), 76.3\left(C_{3^{\prime \prime}}\right), 75.7\left(C_{2^{\prime}}\right), 74.0\left(C_{2^{\prime \prime}}\right), 71.0$ $\left(\mathrm{C}_{4^{\prime}}\right), 44.6\left(\mathrm{C}_{5^{\prime \prime}}\right), 42.8\left(\mathrm{C}_{6^{\prime}}\right), 42.5\left(\mathrm{C}_{2^{*}}\right), 37.6\left(\mathrm{C}_{3^{*}}\right)$; HRMS (TOF MS ES $)$ calcd for $\mathrm{C}_{28} \mathrm{H}_{35} \mathrm{~N}_{5} \mathrm{O}_{10}(\mathrm{M}+\mathrm{H})^{+}$ 602.2457 , found 602.2463 .

Urea $\mathbf{2 4 g}$ was prepared according to the general procedure for urea deprotection from urea $\mathbf{2 3 g}$ (21 $\mathrm{mg}, 22.3 \mu \mathrm{mol}, 1$ equiv.) and was obtained as a colourless oil ( $6.3 \mathrm{mg}, 47 \%$ yield over two steps): $\mathrm{R}_{f}$ 0.15 (DCM/MeOH/NH $\mathrm{NH}_{4} \mathrm{OH}$ 14\% 80/18/2); $[\alpha]_{\mathrm{D}}+4$ (c 1.0, $\mathrm{CH}_{2} \mathrm{Cl}_{2}$ ); IR (film); 2945, 2800, 2430, 1780, $1540,1412,1275,1260,764,750 ;{ }^{1} \mathrm{H}$ NMR $(500 \mathrm{MHz}, \mathrm{MeOD}) \delta 7.86$ (d, J J6-H5 $\left.=8.1 \mathrm{~Hz}, 1 \mathrm{H}, \mathrm{H}_{6}\right), 7.26$ (d, $\left.J_{\mathrm{H}^{*}-\mathrm{H} 6^{*}}=8.3 \mathrm{~Hz}, 2 \mathrm{H}, \mathrm{H}_{7^{*}}\right), 7.18\left(\mathrm{~d}, J_{\mathrm{H} 6^{*}-\mathrm{H} 7^{*}}=8.3 \mathrm{~Hz}, 2 \mathrm{H}, \mathrm{H}_{6^{*}}\right), 5.82\left(\mathrm{~d}, J_{\mathrm{H} 1^{\prime}-\mathrm{H} 2^{\prime}}=2.7 \mathrm{~Hz}, 1 \mathrm{H}, \mathrm{H}_{1^{\prime}}\right), 5.71(\mathrm{~d}$, $\left.J_{H 5-H 6}=8.1 \mathrm{~Hz}, 1 \mathrm{H}, \mathrm{H}_{5}\right), 5.11\left(\mathrm{~s}, 1 \mathrm{H}, \mathrm{H}_{1^{\prime \prime}}\right), 4.15-4.01\left(\mathrm{~m}, 5 \mathrm{H}, \mathrm{H}_{2^{\prime}}, \mathrm{H}_{3^{\prime}}, \mathrm{H}_{4^{\prime}}, \mathrm{H}_{4^{\prime \prime}}, \mathrm{H}_{2^{\prime \prime}}\right), 3.97\left(\mathrm{~d}, J_{\mathrm{H}^{\prime \prime}-\mathrm{H} 2^{\prime \prime}}=4.2\right.$ $\left.\mathrm{Hz}, 1 \mathrm{H}, \mathrm{H}_{3^{\prime \prime}}\right), 3.93-3.89\left(\mathrm{~m}, 1 \mathrm{H}, \mathrm{H}_{5^{\prime}}\right), 3.54\left(\mathrm{dd}, J_{H 6^{\prime} \mathrm{a}-H 6^{\prime} b}=14.0, J_{H 6^{\prime} \mathrm{a}-H 5^{\prime}}=5.1 \mathrm{~Hz}, 1 \mathrm{H}, \mathrm{H}_{6^{\prime} \mathrm{a}}\right), 3.42-3.33(\mathrm{~m}$, $\left.1 \mathrm{H}, \mathrm{H}_{6^{\prime} \mathrm{b}}\right), 3.24\left(\mathrm{~d}, J_{\mathrm{H} 5^{\prime \prime} \mathrm{a}-\mathrm{H} 5^{\prime \prime} \mathrm{b}}=12.3 \mathrm{~Hz}, 1 \mathrm{H}, \mathrm{H}_{5^{\prime \prime} \mathrm{a}}\right), 3.14\left(\mathrm{t}, J_{\mathrm{H}^{*}-\mathrm{H} 3^{*}}=6.9 \mathrm{~Hz}, 2 \mathrm{H}, \mathrm{H}_{2^{*}}\right), 3.01\left(\mathrm{dd}, J_{\mathrm{H} 5^{\prime \prime} \mathrm{b}-\mathrm{H} 5^{\prime \prime a}}=\right.$ $\left.12.3, J_{\mathrm{H} 5^{\prime \prime} \mathrm{b}-\mathrm{H} 4^{\prime \prime}}=9.6 \mathrm{~Hz}, 1 \mathrm{H}, \mathrm{H}_{5^{\prime \prime}} \mathrm{b}\right), 2.64\left(\mathrm{t}, J_{\mathrm{H} 4^{*}-\mathrm{H} 2^{*}}=7.7 \mathrm{~Hz}, 2 \mathrm{H}, \mathrm{H}_{4^{*}}\right), 1.77\left(\mathrm{dt}, J_{\mathrm{H}^{*}-\mathrm{H} 4^{*}}=7.7, J_{\mathrm{H}^{*}-\mathrm{H} 2^{*}}=6.9\right.$ $\left.\mathrm{Hz}, 2 \mathrm{H}, \mathrm{H}_{3^{*}}\right) ;{ }^{13} \mathrm{C}$ NMR $(125 \mathrm{MHz}, \mathrm{MeOD}) \delta 166.1\left(\mathrm{C}_{4}\right), 161.2\left(\mathrm{C}_{8^{\prime}}\right), 152.2\left(\mathrm{C}_{2}\right), 141.9\left(\mathrm{C}_{8^{*}}\right), 142.1\left(\mathrm{C}_{6}\right)$, $132.7\left(C_{5^{*}}\right), 131.0\left(C_{6^{*}}\right), 129.5\left(C_{7^{*}}\right), 110.7\left(C_{1^{\prime \prime}}\right), 102.4\left(C_{5}\right), 91.5\left(C_{1^{\prime}}\right), 84.8\left(C_{3^{\prime}}\right), 81.0\left(C_{4^{\prime \prime}}\right), 78.3\left(C_{5^{\prime}}\right), 76.3$ $\left(C_{3^{\prime \prime}}\right), 75.7\left(C_{2^{\prime}}\right), 74.0\left(C_{2^{\prime \prime}}\right), 71.0\left(C_{4^{\prime}}\right), 44.9\left(C_{5^{\prime \prime}}\right), 42.9\left(C_{6^{\prime}}\right), 40.5\left(C_{2^{*}}\right), 33.4\left(C_{4^{*}}\right), 33.0\left(C_{3^{*}}\right)$; HRMS (TOF MS ES ${ }^{+}$) calcd for $\mathrm{C}_{25} \mathrm{H}_{34} \mathrm{~N}_{5} \mathrm{O}_{10}(\mathrm{M}+\mathrm{H})^{+} 600.2067$, found 600.2064 .

Urea $24 \mathrm{~h}$ was prepared according to the general procedure for urea deprotection from urea $23 \mathrm{~h} \mathrm{(14}$ $\mathrm{mg}, 13.5 \mu \mathrm{mol}, 1$ equiv.) and was obtained as a colourless oil (5.9 mg, $76 \%$ yields over two steps): $\mathrm{R}_{f}$ 0.10 (DCM/MeOH/ $\mathrm{NH}_{4} \mathrm{OH} 14 \%$ 80/18/2); [ $\left.\alpha\right]_{D}+13$ (c 1.0, MeOH); IR (film): 2934, 2857, 2095, 1704, $1635,1600,1575,1508,1446,1420,1306,1273,1260,1172,1148,1087,1020,938,922,877,844$, 792, 764, 743; ${ }^{1} \mathrm{H}$ NMR (500 MHz, MeOD) $\delta 7.74\left(\mathrm{~d}, J_{\mathrm{H} 6-\mathrm{H} 5}=8.1 \mathrm{~Hz}, 1 \mathrm{H}, \mathrm{H}_{6}\right), 5.71\left(\mathrm{~d}, J_{\mathrm{H}^{\prime}-\mathrm{H} \mathrm{z}^{\prime}}=2.9 \mathrm{~Hz}, 1\right.$ $\left.\mathrm{H}, \mathrm{H}_{1^{\prime}}\right), 5.61\left(\mathrm{~d}, \mathrm{~J}_{\mathrm{H} 5-\mathrm{H} 6}=8.1 \mathrm{~Hz}, 1 \mathrm{H}, \mathrm{H}_{5}\right), 5.02\left(\mathrm{~s}, 1 \mathrm{H}, \mathrm{H}_{1^{\prime \prime}}\right), 4.06-4.00\left(\mathrm{~m}, 3 \mathrm{H}, \mathrm{H}_{3^{\prime}}, \mathrm{H}_{4^{\prime}}, \mathrm{H}_{4^{\prime \prime}}\right), 4.00-3.96$ $\left(m, 1 \mathrm{H}, \mathrm{H}_{2^{\prime \prime}}\right), 3.93\left(\mathrm{~d}, J_{\mathrm{H}^{\prime \prime}-\mathrm{H} 2^{\prime \prime}}=4.5 \mathrm{~Hz}, 1 \mathrm{H}, \mathrm{H}_{3^{\prime \prime}}\right), 3.88\left(\mathrm{~m}, 1 \mathrm{H}, \mathrm{H}_{5^{\prime}}\right), 3.85-3.79\left(\mathrm{~m}, 1 \mathrm{H}, \mathrm{H}_{6^{\prime}} \mathrm{a}\right), 3.46$ (dd, $\left.J_{H 6^{\prime} b-H 6^{\prime a}}=13.9, J_{H 6^{\prime} b-H 5^{\prime}}=5.3 \mathrm{~Hz}, 1 \mathrm{H}, \mathrm{H}_{6^{\prime} \mathrm{b}}\right), 3.32-3.25\left(\mathrm{~m}, 2 \mathrm{H}, \mathrm{H}_{5^{\prime \prime} \mathrm{b}}\right), 3.24-3.22\left(\mathrm{~m}, 1 \mathrm{H}, \mathrm{H}_{2^{*} \mathrm{a}}\right), 3.18-$ $3.14\left(\mathrm{~m}, 1 \mathrm{H}, \mathrm{H}_{2^{*} \mathrm{~b}}\right), 2.97-2.87\left(\mathrm{~m}, 4 \mathrm{H}, \mathrm{H}_{4^{*}}\right), 2.85-2.78\left(\mathrm{~m}, 2 \mathrm{H}, \mathrm{H}_{3^{*}}\right), 1.55-1.50\left(\mathrm{~m}, 4 \mathrm{H}, \mathrm{H}_{5^{*}}\right), 1.23$ (dd, $J=23.5,11.7 \mathrm{~Hz}, 20 \mathrm{H}), 0.84-0.78\left(\mathrm{~m}, 6 \mathrm{H}, \mathrm{H}_{11^{*}}\right) ;{ }^{13} \mathrm{C}$ NMR $(125 \mathrm{MHz}, \mathrm{MeOD}) \delta 166.1\left(\mathrm{C}_{4}\right), 161.5$ $\left(C_{8^{\prime}}\right), 152.1\left(C_{2}\right), 142.2\left(C_{6}\right), 110.8\left(C_{1^{\prime \prime}}\right), 102.5\left(C_{5}\right), 91.6\left(C_{1^{\prime}}\right), 84.5\left(C_{3^{\prime}}\right), 80.8\left(C_{4^{\prime \prime}}\right), 78.3\left(C_{5^{\prime}}\right), 76.3\left(C_{3^{\prime \prime}}\right)$, $75.7\left(C_{2^{\prime}}\right), 74.0\left(C_{2^{\prime \prime}}\right), 71.0\left(C_{4^{\prime}}\right), 55.6\left(C_{3^{*}}\right), 55.2\left(C_{4^{*}}\right), 55.1\left(C_{5^{*}}\right), 44.9\left(C_{5^{\prime \prime}}\right), 42.8\left(C_{6^{\prime}}\right), 37.7,32.9,32.9\left(C_{7}\right)$, 30.7, 30.6, 30.3, 30.3, 30.2, 30.2, 30.2, 30.1, 28.0, 27.6, 25.9, 23.6, $14.4\left(C_{11^{*}}\right)$; HRMS (TOF MS ES ${ }^{+}$) calcd for $\mathrm{C}_{34} \mathrm{H}_{63} \mathrm{~N}_{6} \mathrm{O}_{10}(\mathrm{M}+\mathrm{H})^{+} 715.4600$, found 715.4615 .

Urea 24i was prepared according to the general procedure for urea deprotection from urea $\mathbf{2 3 i}$ ( $8 \mathrm{mg}$, $7.79 \mu \mathrm{mol}, 1$ equiv.) and was obtained as a colourless oil ( $3.2 \mathrm{mg}, 60 \%$ yield over two steps): $\mathrm{R}_{f} 0.15$ (DCM/MeOH/ $\mathrm{NH}_{4} \mathrm{OH} 14 \%$ 80/18/2); $[\alpha]_{D}+16$ (c 1.0, $\mathrm{CH}_{2} \mathrm{Cl}_{2}$ ); IR (film): 3712, 2959, 2808, 2342, 1676, 1600, 1379, 1204, 977; ${ }^{1} \mathrm{H}$ NMR (500 MHz, MeOD) $\delta 8.42\left(\mathrm{~s}, 1 \mathrm{H}, \mathrm{H}_{10^{*}}\right), 7.84\left(\mathrm{~d}, J_{\mathrm{H} 6-\mathrm{H} 5}=8.1 \mathrm{~Hz}, 1 \mathrm{H}, \mathrm{H}_{6}\right)$, $7.81\left(\mathrm{~d}, J_{\mathrm{H} 12^{*}-\mathrm{H} 13^{*}}=9.0 \mathrm{~Hz}, 1 \mathrm{H}, \mathrm{H}_{12^{*}}\right), 7.00\left(\mathrm{~d}, J_{\mathrm{H} 13^{*}-\mathrm{H} 11^{*}}=9.0 \mathrm{~Hz}, 1 \mathrm{H}, \mathrm{H}_{13^{*}}\right), 5.80\left(\mathrm{~d}, J_{\mathrm{H} 1^{\prime}-\mathrm{H} 2^{\prime}}=2.7 \mathrm{~Hz}, 1 \mathrm{H}\right.$, $\left.\mathrm{H}_{1^{\prime}}\right), 5.71\left(\mathrm{~d}, \mathrm{~J}_{\mathrm{H} 5-\mathrm{H} 6}=8.1 \mathrm{~Hz}, 1 \mathrm{H}, \mathrm{H}_{5}\right), 5.13\left(\mathrm{~s}, 1 \mathrm{H}, \mathrm{H} 1^{\prime \prime}\right), 4.17-4.04\left(\mathrm{~m}, 4 \mathrm{H}, \mathrm{H}_{2^{\prime}}, \mathrm{H}_{3^{\prime}}, \mathrm{H}_{4^{\prime}}, \mathrm{H}_{4^{\prime \prime}}, \mathrm{H}_{2^{\prime \prime}}\right), 3.98$ (d, $\left.J_{H 3^{\prime \prime}-\mathrm{H}^{\prime \prime}}=4.2 \mathrm{~Hz}, 1 \mathrm{H}, \mathrm{H}_{3^{\prime \prime}}\right), 3.95-3.91\left(\mathrm{~m}, 1 \mathrm{H}, \mathrm{H}_{5^{\prime}}\right), 3.54\left(\mathrm{~m}, 3 \mathrm{H}, \mathrm{H}_{6^{\prime} \mathrm{a}}, \mathrm{H}_{3^{*}}\right), 3.43\left(\mathrm{dd}, J_{\mathrm{H6^{ \prime }}-\mathrm{H}-\mathrm{H}^{\prime} \mathrm{b}}=13.4, J_{\mathrm{HG}^{\prime} \mathrm{a}-}\right.$ $\left.H^{\prime}=6.7 \mathrm{~Hz}, 1 \mathrm{H}, \mathrm{H}_{6^{\prime} \mathrm{b}}\right), 3.36-3.32\left(\mathrm{~m}, 8 \mathrm{H}, \mathrm{H}_{5^{*}}, \mathrm{H}_{6^{*}}\right), 3.25\left(\mathrm{~d}, \mathrm{~J}_{\mathrm{H} 5^{\prime \prime} \mathrm{a}-\mathrm{H} 5^{\prime \prime} \mathrm{b}}=15.4 \mathrm{~Hz}, 1 \mathrm{H}, \mathrm{H}_{5^{\prime \prime} \mathrm{a}}\right), 3.22-3.14$ 
(m, $\left.2 \mathrm{H}, \mathrm{H}_{2^{*}}\right), 3.10$ (dd, $\left.J_{\mathrm{H} 5^{\prime \prime b}-\mathrm{H} 5^{\prime \prime} \mathrm{a}}=15.4, J_{\mathrm{H} 5^{\prime \prime b}-\mathrm{H} 4^{\prime \prime}}=9.6 \mathrm{~Hz}, 1 \mathrm{H}, \mathrm{H}_{5^{\prime \prime} \mathrm{b}}\right) ;{ }^{13} \mathrm{C}$ NMR (125 MHz, MeOD) $\delta 166.0$ $\left(C_{4}\right), 161.4\left(C_{8^{\prime}}\right), 161.2\left(C_{8^{*}}\right), 152.3\left(C_{2}\right), 146.6\left(C_{10^{*}}\right), 142.2\left(C_{6}\right), 136.2\left(C_{12^{*}}\right), 110.8\left(C_{1^{\prime \prime}}\right), 108.0\left(C_{13^{*}}\right)$, $102.5\left(C_{5}\right), 91.8\left(C_{1^{\prime}}\right), 84.6\left(C_{3^{\prime}}\right), 80.0\left(C_{4^{\prime \prime}}\right), 78.4\left(C_{5^{\prime}}\right), 76.2\left(C_{3^{\prime \prime}}\right), 75.6\left(C_{2^{\prime}}\right), 74.0\left(C_{2^{\prime \prime}}\right), 71.0\left(C_{4^{\prime}}\right), 59.1\left(C_{2^{*}}\right)$, $53.1\left(\mathrm{C}_{6^{*}}\right), 44.6\left(\mathrm{C}_{5^{\prime \prime}}\right), 43.6\left(\mathrm{C}_{5^{*}}\right), 42.9\left(\mathrm{C}_{6^{\prime}}\right), 36.4\left(\mathrm{C}_{3^{*}}\right)$; HRMS (TOF MS ES $)$ calcd for $\mathrm{C}_{28} \mathrm{H}_{39} \mathrm{~F}_{3} \mathrm{~N}_{5} \mathrm{O}_{10}(\mathrm{M}+$ $\mathrm{H})^{+} 705.2814$, found 705.2850 .

Urea 24j was prepared according to the general procedure for urea deprotection from urea 23j (11 $\mathrm{mg}, 9.7 \mu \mathrm{mol}, 1$ equiv.) and was obtained as a colourless oil $\left(5.9 \mathrm{mg}, 67 \%\right.$ yields over two steps): $\mathbf{R}_{f}$ 0.10 (DCM/MeOH/NH $\mathrm{NH}_{4} \mathrm{OH}$ 14\% 80/18/2); $[\alpha]_{\mathrm{D}}+7$ (c 1.0, MeOH); IR (film): 2926, 2900, 2454, 1700, 1698, 1304, 1275, 1260, 1206, 1180, 764, 750; ${ }^{1} \mathrm{H}$ NMR (500 MHz, MeOD) $\delta 7.85$ (d, $J_{\mathrm{H} 6-\mathrm{H} 5}=8.1 \mathrm{~Hz}, 1 \mathrm{H}$, $\left.\mathrm{H}_{6}\right), 7.45\left(\mathrm{~d}, \mathrm{~J}_{\mathrm{H} 13^{*}-\mathrm{H} 14^{*}}=7.7 \mathrm{~Hz}, 4 \mathrm{H}, \mathrm{H}_{13^{*}}\right), 7.30\left(\mathrm{t}, J_{\mathrm{H}_{1} 4^{*}-\mathrm{H} 13^{*}}=7.7 \mathrm{~Hz}, 4 \mathrm{H}, \mathrm{H}_{14^{*}}\right), 7.21\left(\mathrm{t}, J_{\mathrm{H} 15^{*}-\mathrm{H} 14^{*}}=7.4 \mathrm{~Hz}\right.$, $\left.2 \mathrm{H}, \mathrm{H}_{15^{*}}\right), 5.81\left(\mathrm{~d}, J_{\mathrm{H}^{\prime}-\mathrm{H} 2^{\prime}}=2.8 \mathrm{~Hz}, 1 \mathrm{H}, \mathrm{H}_{1^{\prime}}\right), 5.71\left(\mathrm{~d}, J_{\mathrm{H} 5-\mathrm{H} 6}=8.1 \mathrm{~Hz}, 1 \mathrm{H}, \mathrm{H}_{5}\right), 5.12\left(\mathrm{~s}, 1 \mathrm{H}, \mathrm{H}_{1^{\prime \prime}}\right), 4.40(\mathrm{~s}, 1$ $\left.\mathrm{H}, \mathrm{H}_{13^{*}}\right), 4.17-4.08\left(\mathrm{~m}, 4 \mathrm{H}, \mathrm{H}_{2^{\prime}} \mathrm{H}_{3^{\prime}} \mathrm{H}_{4^{\prime}} \mathrm{H}_{4^{\prime \prime}}\right), 4.05\left(\mathrm{~m}, 1 \mathrm{H}, \mathrm{H}_{2^{\prime \prime}}\right), 3.97$ (d, $\left.J_{\mathrm{H}^{\prime \prime}-\mathrm{H} 2^{\prime \prime}}=4.3 \mathrm{~Hz}, 1 \mathrm{H}, \mathrm{H}_{3^{\prime \prime}}\right), 3.91$

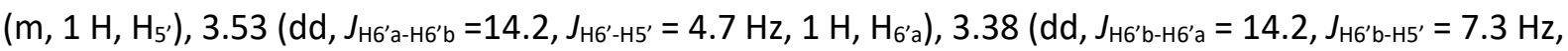
$1 \mathrm{H}, \mathrm{H}_{6^{\prime} \mathrm{b}}$ ), 3.33 (d, J $\left.\mathrm{H}_{5^{\prime \prime}-\mathrm{H} 4^{\prime \prime}}=14.1 \mathrm{~Hz}, 2 \mathrm{H}, \mathrm{H}_{5^{\prime \prime}}\right), 3.15-3.02\left(\mathrm{~m}, 8 \mathrm{H}, \mathrm{H}_{10^{*}} \mathrm{H}_{11^{*}}\right), 1.71$ (dd, $J_{\mathrm{H}^{*}-\mathrm{H} 8^{*}}=10.5,8.2$ $\left.\mathrm{Hz}, 2 \mathrm{H}, \mathrm{H}_{9^{*}}\right), 1.51-1.43\left(\mathrm{~m}, 2 \mathrm{H}, \mathrm{H}_{2^{*}}\right), 1.42-1.26(\mathrm{~m}, 12 \mathrm{H}) ;{ }^{13} \mathrm{C} \mathrm{NMR}(125 \mathrm{MHz}, \mathrm{MeOD}) \delta 166.1\left(\mathrm{C}_{4}\right)$, $161.2\left(C_{2^{\prime}}\right), 152.2\left(C_{2}\right), 143.0\left(C_{13^{*}}\right), 142.1\left(C_{6}\right), 129.9\left(C_{15^{*}}\right), 128.9\left(C_{14^{*}}\right), 128.5\left(C_{15^{*}}\right), 110.8\left(C_{1^{\prime \prime}}\right), 102.5$ $\left(C_{5}\right)$, $91.6\left(C_{1^{\prime}}\right), 84.8\left(C_{3^{\prime}}\right), 80.0\left(C_{4^{\prime \prime}}\right), 78.1\left(C_{5^{\prime}}\right), 76.4\left(C_{12^{*}}\right), 76.3\left(C_{3^{\prime \prime}}\right), 75.6\left(C_{2^{\prime}}\right), 74.0\left(C_{2^{\prime \prime}}\right), 71.0\left(C_{4^{\prime}}\right), 58.04$ $\left(C_{9^{*}}\right), 53.5\left(C_{11^{*}}\right), 50.1\left(C_{10^{*}}\right), 44.6\left(C_{5^{\prime \prime}}\right), 42.9\left(C_{6^{\prime}}\right), 41.1\left(C_{2^{*}}\right), 31.2\left(C_{9^{*}}\right), 30.7\left(C_{3^{*}}\right)$, 30.1, 30.1, 27.9, 27.6, 25.1; HRMS (TOF MS ES ${ }^{+}$) calcd for $\mathrm{C}_{41} \mathrm{H}_{60} \mathrm{~N}_{7} \mathrm{O}_{10}(\mathrm{M}+\mathrm{H})^{+} 810.4396$, found 810.44043.

Urea 24k was prepared according to the general procedure for urea deprotection from urea $\mathbf{2 3 \mathbf { k }}$ (12 $\mathrm{mg}, 10.7 \mu \mathrm{mol}, 1$ equiv.) and was obtained as a colourless oil $\left(2.8 \mathrm{mg}, 41 \%\right.$ yield over two steps): $\mathrm{R}_{f}$ 0.10 (DCM/MeOH/ $\mathrm{NH}_{4} \mathrm{OH} 14 \%$ 80/18/2); $[\alpha]_{\mathrm{D}}+3$ (c 1.0, MeOH); IR (film): 3300, 2926, 1681, 1463, 1275, 1260, 1203, 1133, 764, 750; ${ }^{1} \mathrm{H}$ NMR (500 MHz, MeOD) $\delta 7.85$ (d, J J6-H5 $=8.1 \mathrm{~Hz}, 1 \mathrm{H}, \mathrm{H}_{6}$ ), 5.81 (d, $\left.J_{H 1^{\prime}-\mathrm{H}^{\prime}}=2.7 \mathrm{~Hz}, 1 \mathrm{H}, \mathrm{H}_{1^{\prime}}\right), 5.70\left(\mathrm{~d}, J_{\mathrm{H} 5-\mathrm{H} 6}=8.1 \mathrm{~Hz}, 1 \mathrm{H}, \mathrm{H}_{5}\right), 5.12\left(\mathrm{~s}, 1 \mathrm{H}, \mathrm{H}_{1^{\prime \prime}}\right), 4.17-4.07\left(\mathrm{~m}, 4 \mathrm{H}, \mathrm{H}_{2^{\prime}}, \mathrm{H}_{3^{\prime}}\right.$, $\left.\mathrm{H}_{4^{\prime}}, \mathrm{H}_{4^{\prime \prime}}\right), 4.05\left(\mathrm{~d}, \mathrm{~J}_{\mathrm{H}^{\prime \prime}-\mathrm{H} 3^{\prime \prime}}=4.4 \mathrm{~Hz}, 1 \mathrm{H}, \mathrm{H}_{2^{\prime \prime}}\right), 3.98\left(\mathrm{~d}, J_{\mathrm{H} 3^{\prime \prime}-\mathrm{H} 2^{\prime \prime}}=4.4 \mathrm{~Hz}, 1 \mathrm{H}, \mathrm{H}_{3^{\prime \prime}}\right), 3.94-3.89\left(\mathrm{~m}, 1 \mathrm{H}, \mathrm{H}_{5^{\prime}}\right)$, $3.54\left(\mathrm{dd}, J_{H 6^{\prime} \mathrm{a}-H 6^{\prime} \mathrm{b}}=14.0, J_{H 6^{\prime} \mathrm{a}-H 5^{\prime}}=4.6 \mathrm{~Hz}, 1 \mathrm{H}, \mathrm{H}_{6^{\prime} \mathrm{a}}\right), 3.45\left(\mathrm{~m}, 1 \mathrm{H}, \mathrm{H}_{6^{\prime} \mathrm{b}}\right), 3.43-3.35\left(\mathrm{~m}, 2 \mathrm{H}, \mathrm{H}_{5^{\prime \prime}}\right), 3.18-$ $3.03\left(\mathrm{~m}, 4 \mathrm{H}, \mathrm{H}_{10^{*}}\right), 1.70\left(\mathrm{~s}, 4 \mathrm{H}, \mathrm{H}_{11^{*}}\right), 1.48\left(\mathrm{~m}, 2 \mathrm{H}, \mathrm{H}_{3^{*}}\right), 1.42-1.24(\mathrm{~m}, 42 \mathrm{H}), 0.91\left(\mathrm{t}, J_{\mathrm{H} 17^{*}-\mathrm{H} 16^{*}}=6.8 \mathrm{~Hz}\right.$, $\left.6 \mathrm{H}, \mathrm{H}_{17^{*}}\right) ;{ }^{13} \mathrm{C}$ NMR (125 MHz, MeOD) $\delta 166.0\left(\mathrm{C}_{4}\right), 161.2\left(\mathrm{C}_{8^{\prime}}\right), 152.2\left(\mathrm{C}_{2}\right), 142.1\left(\mathrm{C}_{6}\right), 110.8\left(\mathrm{C}_{1^{\prime \prime}}\right), 102.4$ $\left(C_{5}\right)$, $91.6\left(C_{1^{\prime}}\right), 84.7\left(C_{3^{\prime}}\right), 79.9\left(C_{4^{\prime \prime}}\right), 78.1\left(C_{5^{\prime}}\right), 76.2\left(C_{3^{\prime \prime}}\right), 75.7\left(C_{2^{\prime}}\right), 74.0\left(C_{2^{\prime \prime}}\right), 71.0\left(C_{4^{\prime}}\right), 54.3\left(C_{9^{*}}\right), 54.2$ $\left(C_{10^{*}}\right), 44.6\left(C_{5^{\prime \prime}}\right), 42.9\left(C_{6^{\prime}}\right), 41.1\left(C_{2^{*}}\right), 32.9\left(C_{8^{*}}\right), 31.3\left(C_{3^{*}}\right), 30.7,30.3,30.2,30.1,30.1,27.8,27.6,24.9$, 24.8, 23.6, $14.4\left(\mathrm{C}_{16}{ }^{*}\right)$; HRMS (TOF MS ES ${ }^{+}$) calcd for $\mathrm{C}_{40} \mathrm{H}_{75} \mathrm{~N}_{6} \mathrm{O}_{10}(\mathrm{M}+\mathrm{H})^{+}$799.5539, found 799.55518.

1-butyl-3-(2-(dioctylamino)ethyl)urea 27. To a solution of $n$-butylamine ( $62.5 \mu \mathrm{L}, 632 \mu \mathrm{mol}, 1.2$ equiv.) in dry DCM $(6 \mathrm{~mL})$ were added triethylamine $(220 \mu \mathrm{l}, 1.58 \mathrm{mmol}, 3.0$ equiv.) and carbonyldiimidazole (102 mg, $632 \mu \mathrm{mol}, 1.2$ equiv.). The resulting mixture was stirred at $0{ }^{\circ} \mathrm{C}$ for $10 \mathrm{~min}$ and then $3 \mathrm{~h}$ at R.T. The $N^{1}, N^{1}$-dioctyloctane-1,2-diamine $13 \mathrm{~h}$ (150 mg, $527 \mu \mathrm{mol}, 1$ equiv.) was dissolved in dry DCM (3 $\mathrm{mL}$ ), added dropwise to the reaction mixture and stirred at $30^{\circ} \mathrm{C}$. After $12 \mathrm{~h}$, the mixture was concentrated in vacuo. Flash chromatography of the residue (EtOAc) afforded the urea $\mathbf{2 7}$ as a colorless oil (166 mg, 68\% yield): $\mathrm{R}_{f} 0.20$ (EtOAc/ $\mathrm{MeOH} / \mathrm{NH}_{4} \mathrm{OH}_{\text {aq. }} .4 \%=99 / 1 / 0.1$ ); IR (film): 2957, 2929, 2857, 1634, 1577, 1467, 1266; ${ }^{1} \mathrm{H}$ NMR $(500 \mathrm{MHz}, \mathrm{MeOD}) \delta 3.19\left(\mathrm{t}, J_{\mathrm{H} 1-\mathrm{H} 2}=6.6 \mathrm{~Hz}, 2 \mathrm{H}, \mathrm{H}-1\right), 3.10\left(\mathrm{t}, J_{\mathrm{H} 1}\right.$ '$\left.\mathrm{H}^{\prime}=7.0 \mathrm{~Hz}, 2 \mathrm{H}, \mathrm{H}-1^{\prime}\right), 2.54\left(\mathrm{t}, J_{\mathrm{H} 1-\mathrm{H} 2}=6.6 \mathrm{~Hz}, 2 \mathrm{H}, \mathrm{H}-2\right), 2.49-2.43(\mathrm{~m}, 4 \mathrm{H}, \mathrm{H}-3), 1.52-1.41(\mathrm{~m}, 6 \mathrm{H}, \mathrm{H}-4$, $\left.\mathrm{H}-2^{\prime}\right), 1.41-1.23\left(\mathrm{~m}, 22 \mathrm{H}, \mathrm{H}-3^{\prime}, \mathrm{H}-5, \mathrm{H}-6, \mathrm{H}-7, \mathrm{H}-8, \mathrm{H}-9\right), 0.94\left(\mathrm{t}, J_{\mathrm{H} 3^{\prime}-\mathrm{H} 4^{\prime}}=7.3 \mathrm{~Hz}, 3 \mathrm{H}, \mathrm{H}-4^{\prime}\right), 0.91$ (t, J J $\mathrm{H}_{-\mathrm{H} 10}$ $=7.0 \mathrm{~Hz}, 6 \mathrm{H}, \mathrm{H}-10) ;{ }^{13} \mathrm{C}$ NMR (500 MHz, MeOD) $\delta 161.3(\mathrm{CO}), 55.5\left(\mathrm{C}_{3}\right), 55.0\left(\mathrm{C}_{2}\right), 40.8\left(\mathrm{C}_{1^{\prime}}\right), 38.8\left(\mathrm{C}_{1}\right)$, $33.5\left(C_{2^{\prime}}\right), 33.1,30.7,30.5,28.7,27.8,23.8\left(C_{4}, C_{5}, C_{6}, C_{7}, C_{8}, C_{9}\right), 21.1\left(C_{3^{\prime}}\right), 14.5\left(C_{10}\right), 14.2\left(C_{4^{\prime}}\right)$; HRMS $\mathrm{APCl}^{+}$calcd for $\mathrm{C}_{23} \mathrm{H}_{50} \mathrm{~N}_{3} \mathrm{O}^{+}(\mathrm{M}+\mathrm{H})^{+} 384.3948$, found 384.3932 .

\section{Enzymatic assays}


The inhibitory activity of the synthesized $N, N^{\prime}$-disubstituted ureas $\mathbf{2 4 a - k}$, and their unprotected amino precursor 12, was evaluated on His-tagged MraY transferase purified from Aquifex aeolicus $\left(\mathrm{MraY}_{\mathrm{AA}}\right)$ prepared as previously described by Chung et al. ${ }^{23}$ The assays were performed as previously described by Stachyra et al. ${ }^{46}$ in 96 -well plates in a total reaction mixture of $100 \mu \mathrm{L}$ containing $100 \mathrm{mM}$ of Tris- $\mathrm{HCl}(\mathrm{pH} 7.5), 40 \mathrm{mM} \mathrm{MgCl}, 150 \mu \mathrm{M} \mathrm{C}_{55}-\mathrm{P}, 150 \mathrm{mM} \mathrm{NaCl}, 25 \mu \mathrm{M}$ dansylated UDP-MurNAcpentapeptide and $0.4 \%$ of $n$-dodecyl $\beta$-D-maltoside. The reaction was initiated by the addition of pure MraY $_{A A}$ enzyme $(10 \mu \mathrm{L}, 0.036 \mathrm{mg} / \mathrm{mL})$. Briefly, MraY catalyses the formation of lipid I displaying an apolar environment from polar and hydrosoluble dansylated-UDP-MurNAc-pentapeptide. This modification in the environment of the dansyl probe is accompanied by an enhancement (3.4 times) of fluorescence as well as a shift of the maximum of fluorescence emission spectrum from $560 \mathrm{~nm}$, for the dansylated nucleotidic substrate, to $530 \mathrm{~nm}$ for the dansylated lipid product (see Fig. 2 in Stachyra et $a l .{ }^{46}$ ). This property was exploited to develop an HTS assay ${ }^{46}$ and to assess MraY activity by using an Enspire fluorescence microplate reader (Perkin-Elmer, Courtaboeuf, France). The fluorescence measurement was read every two minutes at $37{ }^{\circ} \mathrm{C}$ under shaking during $60 \mathrm{~min}$, the excitation wavelength and the emission wavelength are $340 \mathrm{~nm}$ and $530 \mathrm{~nm}$, respectively. Experiments were performed in triplicate and each experiment was repeated at least twice. In each case, the fluorescence of a control sample without enzyme was subtracted, initial velocity was calculated and percent inhibition was deduced. $I C_{50}$ values were determined from plots of the percent inhibition versus the inhibitor concentration and data were processed on Excel software.

\section{Antibacterial activity}

Tests were made using 48-wells microtitration plates, in $250 \mu \mathrm{L}$ (final volume) of Müeller-Hinton Broth (MHB), following EUCAST (European Committee on Antimicrobial Susceptibility testing) /CLSI (Clinical and Laboratory Standard Institute) recommended procedure ${ }^{47}$ This microtitration plate size allows direct detection of bacterial growth in a relatively small volume, without the use of a spectrophotometer or the addition of dyes. Molecules were solubilised in $100 \%$ DMSO (cell culture grade) at $20.48 \mathrm{mg} / \mathrm{mL}$ concentration, and 40 -fold diluted in MHB, to reduce DMSO concentration in the antibacterial test, just before utilization. The MHB-diluted solutions were then serialy two-fold diluted in $\mathrm{MHB}$, at final concentration ranging from $128 \mu \mathrm{g} / \mathrm{mL}$ to $1 \mu \mathrm{g} / \mathrm{mL}$. Bacterial inoculums were prepared for each strain, resuspending isolated colonies from $18 \mathrm{~h}$ cultured plates. Equivalents of 0.5 Mac Farland turbidity standard (approximately $1.108 \mathrm{CFU} / \mathrm{mL}$ ) were prepared in saline solution $(\mathrm{NaCl}$ $0.085 \%$ ) and diluted 200 -fold in $\mathrm{MBH}$. The bacterial suspensions were then added to microplates containing the diluted molecules. Microtitration plates were incubated overnight at $37^{\circ} \mathrm{C}$. MICs were determined as the lowest dilution of product showing no visual turbidity.

\section{Docking}

Ligands and proteins preparation, calculations and analysis were performed in Discovery Studio (Dassault Systèmes BIOVIA, Discovery Studio Modeling Environment, Release 2016, San Diego: Dassault Systèmes, 2015). Crystal structures of $\mathrm{MraY}_{\mathrm{AA}}$ bound with Muraymycin D2 and carbacaprazamycin were downloaded from the Protein Data Bank (PDB code 5CKR and 6OYH). All water molecules except for W506 in 5CKR were removed from the active site then proteins preparation was performed using default parameters of the Protein Preparation protocol. Missing loops were built with the Modeler program $9.15{ }^{48}$ Hydrogen atom positions were minimized with $\mathrm{CHARMm}^{49}$ using the CHARMm 40.1 force field. Ligands were prepared using the Prepare Ligand module in DS. Ionization states were calculated at target $\mathrm{pH} 7.4 \pm 1.0$. A maximum of 255 random conformations were generated for each 
ligand to improve the coverage of the conformational space using the BEST algorithm. ${ }^{50}$ Docking studies were performed using CDOCKER ${ }^{51} 10$ docking poses per ligand were generated with postdocking minimization with CHARMm enabled to ensure the convergence of conformational sampling. Default values were used for all other docking parameters. The top-ranking poses of each compound according to the CDOCKER interaction Energy scoring function were selected then protein-ligand interactions analyzed. Rigid re-docking of Muraymycin D2 and carabcaprazamycin into the MraY binding site of $5 \mathrm{CKR}$ and $60 \mathrm{YH}$ were performed for the validation of docking protocole.

\section{Molecular Dynamics}

Molecular dynamics (MD) simulations were performed using NAMD with the CHARMM $36 \mathrm{~m}$ force field ${ }^{52}$ implemented in BIOVIA DS 2020. The MraY-ligand complex was embedded in a DPPC lipid bilayer using the Solvate with Explicit Membrane protocole implemented in Biovia Discovery studio 2020. The membrane was properly positioned using the Orientations of Proteins in Membranes (OPM) database (https://opm.phar.umich.edu/). Solvation was carried out in a orthorhombic box with TIP3P water molecules and $\mathrm{NaCl}$ counterions. The system was equilibrated starting with a 1000-step minimization minimized followed by three stages of NVT or NPT dynamics for $4 \mathrm{~ns}$. During the NVT stage, the protein was kept fixed. The lipid heads and solvent molecules were restrained by harmonic restraints. The positional restraint was removed for the lipid heads during the NPT simulation (stage 2). NPT simulation (Stage 3) was run with harmonic restraints on the protein. Finally, a production dynamics of 50ns was performed in NPT conditions at $300 \mathrm{~K}$ without any constraints.

\section{Author contribution}

M. O.: participated to the design of and conducted chemical experiments, analyzed and interpreted the data and participated to the writing of the manuscript (experimental part) ; L. L. C. : designed the molecular docking and dynamics simulations, analyzed and interpreted the data and participated to the writing of the manuscript; M. P. : conducted enzymatic tests, analyzed and interpreted the data ; A. C.: conducted chemical experiments, analyzed and interpreted the data ; L. M. : conducted chemical experiments; M. B.: participated to the conceptualization of the study, supervised chemistry experiments, interpreted the data, participated to the writing of the manuscript; A. A. and B. J. : conducted and acquired cellular biology experiments, analyzed and interpreted the data and participated to the writing of the manuscript; R. A. and T. T. : prepared MraY enzyme ; A. B. : designed the inhibition test conditions, supervised enzymatic assays and the interpretation of the data ; S. C. V. and C.G.P.: conceptualized the study, designed the chemistry experiments, analyzed and interpreted the data, wrote the manuscript and performed project administration. All authors have read and agreed to the published version of the manuscript.

\section{Conflict of interest}

There are no conflicts of interest to declare

\section{Acknowledgments}


We thank the "Centre National de la Recherche Scientifique" and the "Ministère de l'Enseignement Supérieur et de la Recherche" for financial support of this work and for M. O. PhD grant. We warmly thank Dr D. Padovani (CNRS UMR 8601) for his interest in this work and for helpful discussion. This work has benefited from the facilities and expertise of the Small Molecule Mass Spectrometry platform of IMAGIF (Centre de Recherche de Gif - www.imagif.cnrs.fr). The assistance of P. Gerardo (Université de Paris) for low resolution and high resolution mass spectra analyses is gratefully acknowledged. We acknowledge the Macromolecular Modelling Platform and the NMR platform core facilities of the BioTechMed facilities INSERM US36 I CNRS UMS2009 I Université de Paris for docking and MD simulation and NMR experiments, respectively.

\section{Bibliographic references and notes}

$1 \quad$ C. L. Ventola, $P$ \& T, 2015, 40, 277-283.

2 B. Aslam, W. Wang, M. I. Arshad, M. Khurshid, S. Muzammil, M. H. Rasool, M. A. Nisar, R. F. Alvi, M. A. Aslam, M. U. Qamar, M. K. F. Salamat, Z.Baloch, Infect. Drug Resist. 2018, 11, 1645-1658.

3 J. O'Neill, Antimicrobial Resistance: Tackling a crisis for the health and wealth of nations. London: Review on Antimicrobial Resistance. 2014.

4 O. O. Adeyi, E. Baris, O. B. Jonas, A. Irwin, F. C. J. Berthe, F. G. Le Gall, P. V. Marquez, I. A. Nikolic, C. A. Plante, M. Schneidman, D. E. Shriber, A. Thiebaud, "Drug-resistant infections: A threat to our economic future (vol. 2): Final report" (World Bank Group, 2017).

5 L. S. J. Roope, R. D. Smith, K. B. Pouwels, J. Buchanan, L. Abel, P. Eibich, C. C. Butler, P. S. Tan, A. S. Walker, J. V. Robotham, S. Wordsworth, Science, 2019, 364, eaau4679.

6 M. E. de Kraker, A. J. Stewardson, S. Harbarth, PLOS Med., 2016, 13, e1002184.

7 A. Cassini, L. Diaz Högberg, D. Plachouras, A. Quattrocchi, G. S. Simonsen, M. Colomb-Cotinat, M. E. Kretzschmar, B. Devleesschauwer, M. Cecchini, D. A. Ouakrim, T. C. Oliveira, M. J. Struelens, C. Suetens, D. L. Monnet, Lancet Infect. Dis., 2019, 19, 56-66.

8 K. H. Luepke K. J. Suda, H. Boucher, R. L. Russo, M. W. Bonney, T. D. Hunt, J. F. Mohr 3rd, Pharmacotherapy, 2017, 37, 71-84.

9 J. van Heijenoort, Nat. Prod. Rep. 2001, 18, 503-519.

10 M. Bassetti, E. Righi, Langenbecks Arch. Surg. 2015, 400, 153-165.

11 Y. Liu, E. Breukink, Antibiotics, 2016, 5, 28; doi:10.3390/antibiotics5030028.

12 H. Barreteau, A. Kovač, A. Boniface, M. Sova, S. Gobec, D. Blanot, FEMS Microbiol. Rev., 2008, 32, 168-207.

13 A. Bouhss, D. Mengin-Lecreulx, D. Le Beller, J. van Heijenoort, Mol. Microbiol., 1999, 34, 576-585.

14 A. Takatsuki, G. Tamura, J. Antibiot., 1971, 24, 232-238.

15 (a) M. Ubukata and K. Isono, J. Am. Chem. Soc., 1988, 4416-4417; (b) M. Ubukata, K. Kimura, K. Isono, C. C. Nelson, J. M. Gregson and J. McCloskey, J. Org. Chem., 1992, 57, 6392-6403; (c) P. E. Brandish, K. I. Kimura, M. Inukai, R. Southgate, J. T. Lonsdale and T. D. H. Bugg, Antimicrob. Agents Chemother., 1996, 40, 16401644; (d) Y. Esumi, Y. Suzuki, K. Kimura, M. Yoshihama, T. Ichikawa and M. Uramoto, J. Antibiot., 1999, 52, 281-287.

16 (a) M. Igarashi, N. Nakagawa, S. Doi, N. Hattori, H. Naganawa and M. Hamada, J. Antibiot., 2003, 56, 580-583; (b) M. Igarashi, Y. Takahashi, T. Shitara, H. Nakamura, H. Naganawa, T. Miyake and Y. Akamatsu, J. Antibiot., 2005, 58, 327-337.

17 L. A. McDonald, L. R. Barbieri, G. T. Carter, E. Lenoy, J. Lotvin, P. J. Petersen, M. M. Siegel, G. Singh and R. T. Williamson, J. Am. Chem. Soc., 2002, 124, 10260-10261.

18 (a) C. Dini, P. Collette N. Drochon, J. C. Guillot, G. Lemoine, P. Mauvais and J. Aszodi, Bioorg. Med. Chem. Lett., 2000, 10, 1839-1843; (b) C. Dini, N. Drochon, S. Feteanu, J. C. Guillot, C. Peixoto and J. Aszodi, Bioorg. Med. Chem. Lett., 2001, 11, 529-531; (c) C. Dini, N. Drochon, J. C. Guillot, P. Mauvais, P. Walter and J. Aszodi, Bioorg. Med. Chem. Lett., 2001, 11, 533-536.

19 D. Duksin, W. C. Mahoney, J. Biol. Chem., 1982, 257, 3105-3109.

20 (a) B. Patel, P. Ryan, V. Makwana, M. Zunk, S. Rudrawar, G. Grant, Eur. J. Med. Chem., 2019, 171, $462-474$. (b) M. J. Fer, L. Le Corre, N. Pietrancosta, N. Evrard-Todeschi, S. Olatunji, A. Bouhss, S. Calvet-Vitale, C. GravierPelletier, Curr. Med. Chem., 2018, 25, 6013-6025. (c) D. Wiegmann, S. Koppermann, M. Wirth, G.; Niro, K.; 
Leyerer, C. Ducho, Beilstein J. Org. Chem., 2016, 12, 769-795. (d) S. Ichikawa, M. Yamaguchi, A. Matsuda, Curr. Med. Chem., 2015, 22, 3951-3979.

21 M. Winn, R. J. M. Goss, K. Kimura, T. D. H. Bugg, Nat. Prod. Rep., 2010, 27, 279-304.

22 S. Ichikawa, M. Yamaguchi, L. Shang Hsuan, Y. Kato, A. Matsuda, ACS Infect. Dis., 2015, 1, 151-156.

23 B. C. Chung, J. Zhao, R. A. Gillespie, D. Y. Kwon, Z. Guan, J. Hong, P. Zhou, S. Y. Lee, Science, 2013, 341, $1012-$ 1016.

24 B. C. Chung, E. H. Mashalidis, T. Tanino, M. Kim, A. Matsuda, J. Hong, S. Ichikawa, S. Y. Lee, Nature, 2016, 533, 557-560.

25 J. K. Hakulinen, J. Hering, G. Brändén, H. Chen, A. Snijder, M. Ek, P. Johansson, Nat. Chem. Biol., 2017, 13, 265-267.

26 E. H. Mashalidis, B. Kaeser, Y. Terasawa, A. Katsuyama, D. Y. Kwon, K. Lee, J. Hong, S. Ichikawa, S. Y. Lee, Nat. Commun., 2019, 10, 2917-2928.

27 J. Mravljak, O. Monasson, B. Al Dabbagh, M. Crouvoisier, A. Bouhss, C. Gravier-Pelletier, Y. Le Merrer, Eur. J. Med Chem., 2011, 46, 1582-1592.

28 M. J. Fer, S. Olatunji, A. Bouhss, S. Calvet-Vitale, C. Gravier-Pelletier, J. Org. Chem., 2013, 78, 10088-10105.

29 M. J. Fer, A. Bouhss, M. Patrão, L. Le Corre, N. Pietrancosta, A. Amoroso, B. Joris, D. Mengin-Lecreulx, S. CalvetVitale, C. Gravier-Pelletier, Org. Biomol. Chem., 2015, 13, 7193-7222.

30 I. Gallou, Org. Prep. Proced. Int., 2007, 39, 355-383.

31 X. Zhang, J. Rodrigues, L. Evans, B.Hinkle, L Ballantyne, M. Peña, J. Org. Chem., 1997, 62, 6420-6423.

32 Y. Tao, M. S. Lall, D. C. Boyles, S. C. Lilley, S. D. Pattavina, R. J. Rafka, B. J. Sitter, A. Morgan Stewart, J. Szeliga, G.A. Weisenburger, Org. Process Res. Dev. 2019, 23, 2499-2509.

33 I. Gallou, M. Erikson, X. Zeng, C. Senanayake, V. Farina, J. Org. Chem., 2005, 70, 6960-6963.

34 I. Maya, O. Lopez, S. Maza, J. G. Fernandez-Bolanos, J. Fuentes, Tetrahedron Lett., 2003, 44, 8539-8543.

35 Z. Gan, G. Li, Q. Yan, W. Deng, Y.-Y. Jiang, D. Yang, Green Chemistry, 2020, 22, 2956-2962.

36 F. Shi , Y. Q. Deng , T. L. SiMa, H. Z. Yang, Tetrahedron Lett., 2001, 42, 2161-2163.

37 S. A. R. Mulla, C. V. Rode, A. A. Kelkar and S. P. Gupte, J. Mol. Catal. A: Chem., 1997, 122, 103-109.

38 K. Yoo, J. Lee, M. H. Park, Y. Kim, H. J. Kim, M. Kim, J. Org. Chem., 2020, 85, 6233-6241.

39 A. Ion, V. Parvulescu, P. Jacobs, D. De Vos, Green Chem., 2007, 9, 158-161.

40 X. He, C. Yang, Y. Wu, M. Xie, R. Li, J. Duan, Y. Shang, Org. Biomol. Chem., 2020, 18, 4178-4182.

41 M. J. Fer, P. Doan, T. Prangé, S. Calvet-Vitale, C. Gravier-Pelletier, J. Org. Chem., 2014, 79, 7758-7765.

42 S. Hirano, S. Ichikawa, A. Matsuda, Angew. Chem., Int. Ed., 2005, 44, 1854-1856.

43 K. Sudarshan, I. Singh Aidhen, Eur. J. Org. Chem, 2017, 34-38.

44 C. Fong, D. Wells, I. Krodkiewska, P. G. Hartley, C. J. Drummond, Chem. Mater., 2006, 18, 594-597.

45 T. Tanino, B. Al-Dabbagh, D. Mengin-Lecreulx, A. Bouhss, H. Oyama, S. Ichikawa, A. Matsuda, J. Med. Chem., 2011, 54, 8421-8439.

46 T. Stachyra, C. Dini, P. Ferrari, A. Bouhss, J. van Heijenoort, D. Mengin-Lecreulx, D. Blanot, J. Bitton, D. Le Beller, Antimicrob. Agents Chemother. 2004, 48, 897-902.

47 ISO 20776-1 (2006) Clinical laboratory testing and in vitro diagnostic test systems - Susceptibility testing of infectious agents and evaluation of performance of antimicrobial susceptibility test devices - Part 1: Reference method for testing the in vitro activity of antimicrobial agents against rapidly growing aerobic bacteria involved in infectious diseases.

48 A. Sali, T. L. Blundell, J. Mol. Biol. 1993, 234, 779-815.

49 B. R. Brooks, R. E. Bruccoleri, B. D. Olafson, D. J. States, S. Swaminathan, M. Karplus, J. Comput. Chem., 1983, 4, 187-217.

50 A. Smellie, S. Teig, S., P. Towbin, J. Comput. Chem., 1995, 16, 171-187.

51 G. S. Wu, D. H. Robertson, C. L. Brooks, M. Vieth, J. Comput. Chem., 2003, 24, 1549-1562.

52 J. C. Phillips, R. Braun, W. Wang, J. Gumbart, E. Tajkhorshid, E. Villa, C. Chipot, R. D. Skeel, L. Kalé, K. Schulten, J. Comp. Chem., 2005, 26, 1781-1802. 